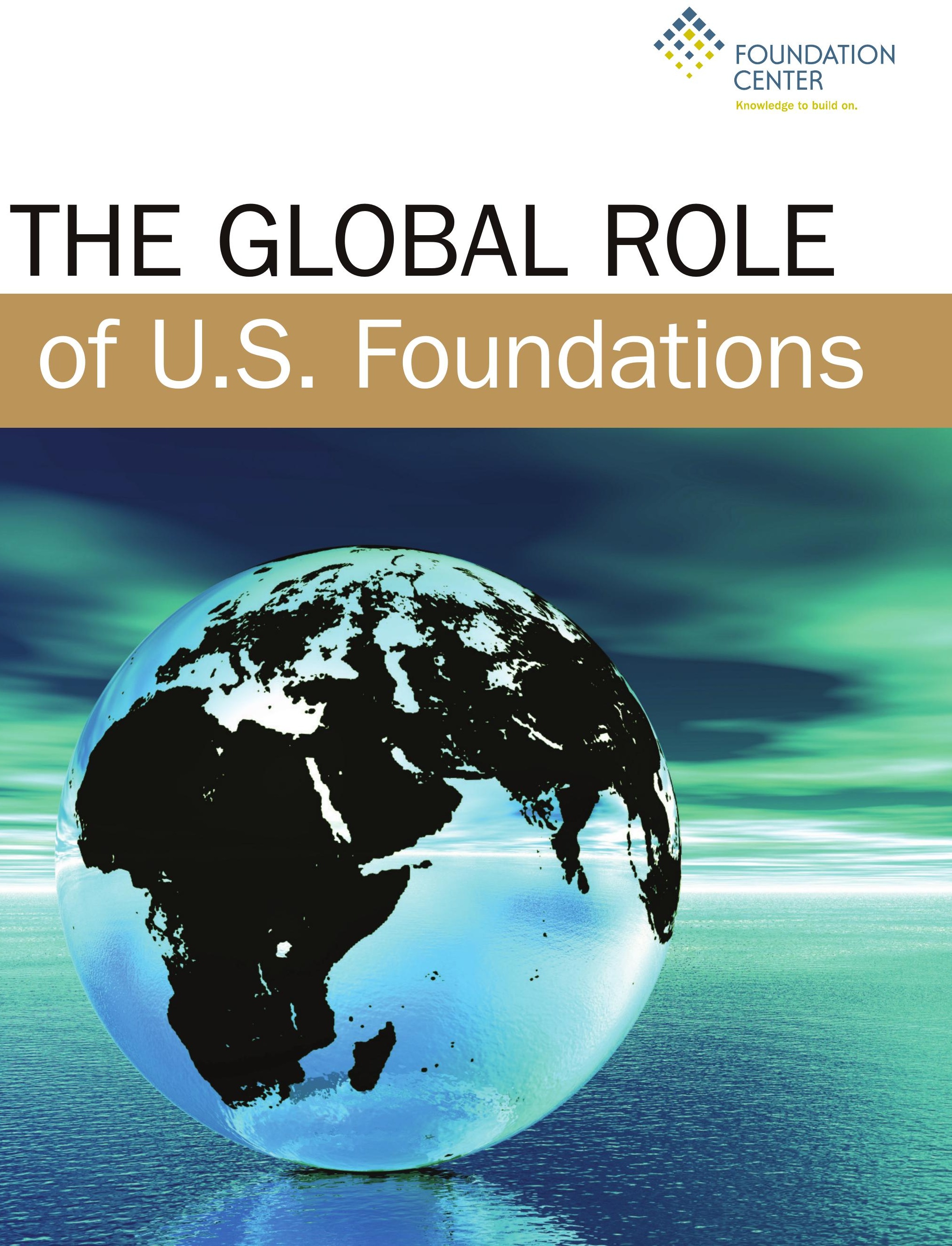




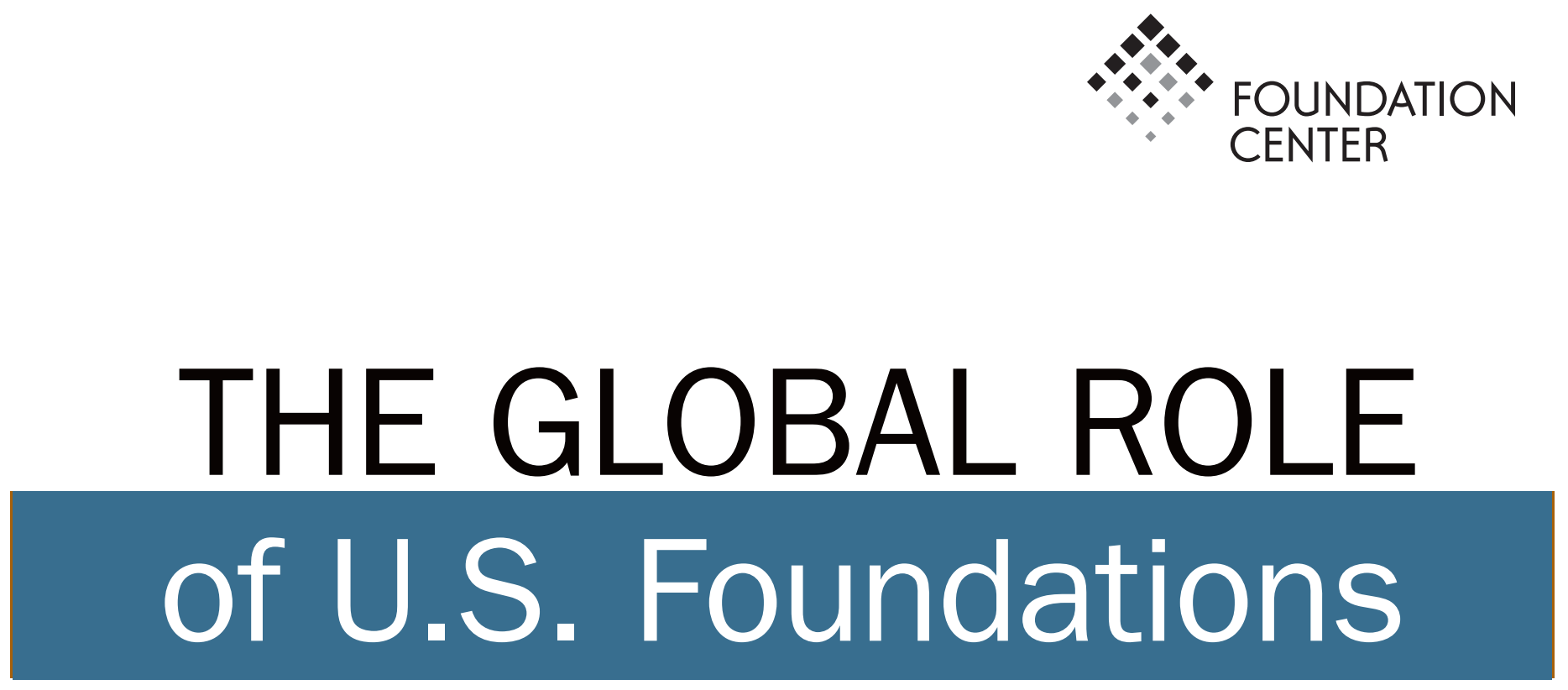

Joan E. Spero

Visiting Fellow 


\section{CONTRIBUTING STAFF}

Marc Almanzor____ Research Associate

Christine Innamorato___ Production Manager

Steven Lawrence___ Director of Research

Lawrence T. McGill___ Vice President for Research

Reina Mukai__ Research Associate

Betty Saronson_ Graphic Design/Production Coordinator

Daniel Saronson__ Research Assistant

Bradford K. Smith__ President

\section{ABOUT THE FOUNDATION CENTER}

Established in 1956 and today supported by close to 550 foundations, the Foundation Center is the nation's leading authority on philanthropy, connecting nonprofits and the grantmakers supporting them to tools they can use and information they can trust. The Center maintains the most comprehensive database on U.S. grantmakers and their grants - a robust, accessible knowledge bank for the sector. It also operates research, education, and training programs designed to advance knowledge of philanthropy at every level. Thousands of people visit the Center's web site each day and are served in its five regional library/learning centers and its network of more than 425 funding information centers located in public libraries, community foundations, and educational institutions in every U.S. state and beyond. For more information, please visit foundationcenter.org or call (212) 620-4230.

(C) 2010 by the Foundation Center. All rights reserved. Printed and bound in the United States of America.

ISBN 978-1-59542-312-2

To order additional copies of this report, visit foundationcenter.org/marketplace or call (800) 424-9836. 


\section{Contents}

PREFACE

INTRODUCTION — ix

A SHORT HISTORY OF INTERNATIONAL PHILANTHROPY _ 1

The Origins of International Philanthropy

Philanthropy and the Cold War ___ 2

Policies at Home___ 3

Japan and Europe __ 3

Developing Countries___ 3

Communist Bloc _ـ 5

GLOBAL PHILANTHROPY IN THE POST-COLD WAR ERA _ 7

The Growth of International Funding ___ 7

Global Challenge: Health Disparities __ 10

The HIV/AIDS Crisis__ 11

Funding Challenges in the Developing World___ 15

Global Challenge: Poverty ___ 16

The New Green Revolution _ 16

Pilot Programs _ 17

Social Entrepreneurship — 18

Impact and Sustainability _ 18

Global Challenge: Climate Change___ 19

The Energy Foundation _ـ 20

ClimateWorks Foundation _ 21

Advocacy —_ 22

Global Challenge: Democracy and Civil Society ___ 22

Eastern Europe and Russia __ 24

Impact and Sustainability _ 27

Global Challenge: Peace and Security ___ 28

International Security Studies __ 29

International Dialogues___ 29

Impact _ 31

ISSUES IN GLOBAL PHILANTHROPY __ 33

Impact _ 33

Global Governance___ 34

Accountability _ـ 37

At Home_ 37

Abroad — 38

Future Global Challenges___ 41

CONCLUSION — 41 



\section{Tables and Figures}

Table 1. International Grants vs. All Grants for Sampled Foundations, 1982 to 2008 2

Figure 1. Total U.S. Foundation Assets, 1990 to 2008

Figure 2. Total U.S. Foundation Giving, 1990 to 2008 7

Figure 3. Growth of Overseas vs. U.S.-Based International Giving, 2002 to 2008 8

Figure 4. International Giving as a Share of Overall Foundation Giving, 1982 to 2008 8

Table 2. Top 25 Foundations by Amount of International Giving, 2008 9

Figure 5. Profile of International Funders in 2008 10

Figure 6. Overseas Giving by Major Region, 2008 11

Figure 7. Giving to U.S.-Based International Programs by Major Region, 2002, 2006, and 2008 11

Figure 8. Amount of International Giving by Major Program Area, 2002, 2006, and 2008 12

Table 3. Top U.S. HIV/AIDS Funders with a Primarily International Focus in 2008 13

Figure 9. Foundation Giving to Overseas Recipients in Eastern Europe, Russia, and the Independent States, 1990 to 2008 24 



\section{Preface}

This study grows out of a personal journey. I joined the philanthropic world in 1997, a time of great change. Foundation assets were growing, new wealth led to the creation of new foundations, and philanthropic activities were expanding around the globe. I viewed all these developments as a newcomer to the philanthropic world. In my prior lives as a business executive, government official, and academic, I had focused on international markets and economic policies around the world, U.S. foreign policy, and global governance. Over my twelve years as a foundation president, I observed and eventually participated in the growing role of foundations in the rapidly globalizing world. I was struck by the political dimension of philanthropy and surprised that most other players-governments, international organizations, global corporations and financial institutions plus academic and think tank observers-paid little attention to the global role and reach of U.S. foundations. It seemed to me that most foundation leaders did not see themselves and their organizations as political players but, rather, as supporters of social change.

When I stepped down as President of Doris Duke Charitable Foundation at the end of 2008, the Trustees of the Foundation generously offered me a sabbatical year, which I have used to research, think, and write about global philanthropy. The President of the Foundation Center suggested I spend my sabbatical there as a Visiting Fellow. The Center and its talented staff have been wonderful hosts, offering me not only an office but also access to its superb data base and library as well as research and administrative support.

I am grateful to my colleagues at the Foundation and the Center as well as my research assistants Veronique
Mistycki, Andrea Wong, and Joseph Lin who helped immensely with the substance of my research; to the many foundation presidents and program officers, and experts whom have shared their knowledge and insights about the work of their foundations and the philanthropic field more broadly; to those inside and outside the philanthropic world who offered advice and much needed criticism on my paper. They have all enriched and enlightened me and improved this study enormously.

In the end, of course, this study reflects my own personal perspective, that private foundations are political actors pursuing foreign policies and playing an important role in the new global world. I believe that foundations have not only great potential as global players, but also a great responsibility to play that role wisely and well.

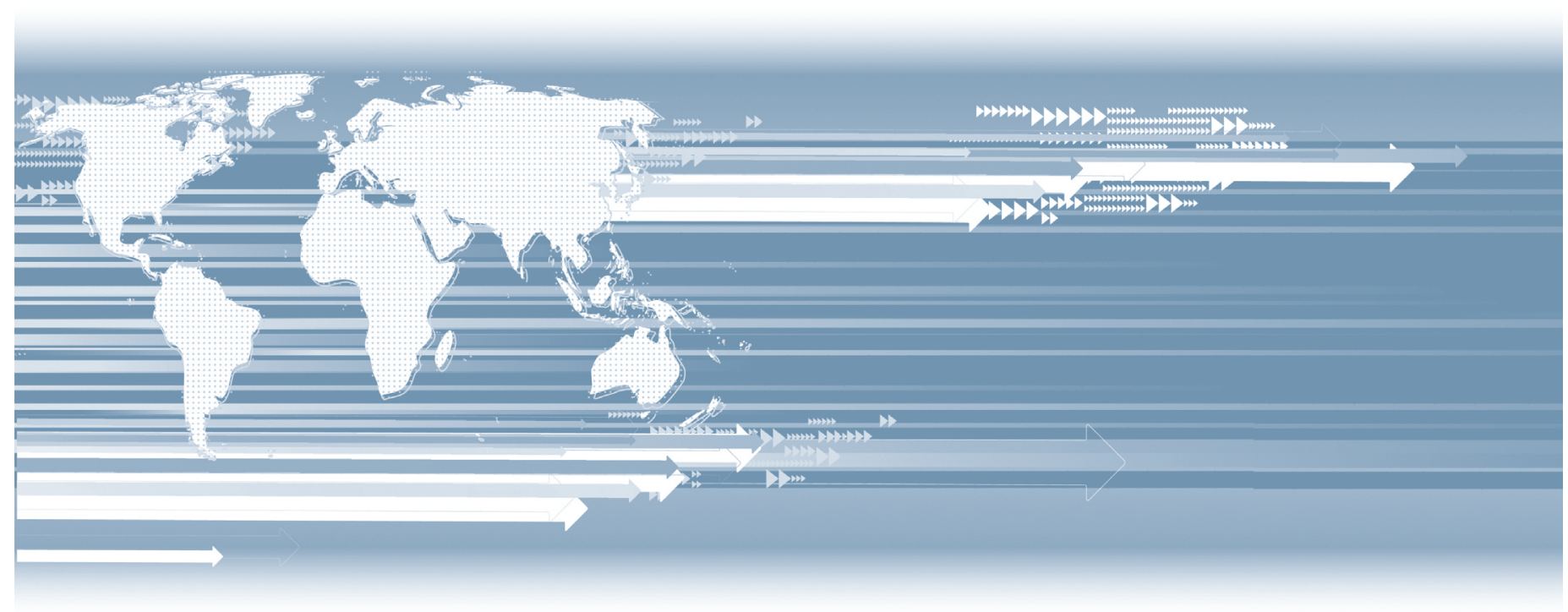





\section{Introduction}

One of the central characteristics of today's global world is the growing role of non-state actors including global corporations, financial institutions, and non-profit organizations as well as criminal and terrorist groups. Interestingly, one important nonstate actor, the private foundation, has received little attention. While the names of the Ford, Rockefeller, or Gates foundations may be familiar, there is little awareness of or knowledge about the global reach and the global role of these and other private foundations that have endowments and make grants, and whose purpose is to serve the public good. ${ }^{1}$

Yet, U.S. private foundations have become important global actors pursuing social, economic, and political change around the world. In the last two decades, there has been a significant increase in their number, the size of their assets, and the scale of their international funding. In 2008, international funding by U.S. private foundations_-including funding for overseas recipients and U.S.-based international programs_-reached $\$ 6.2$ billion, a significant amount when compared with total U.S. government overseas development assistance of $\$ 26$ billion that year. Although foundations have become important global actors, surprisingly little is known about their international policies and practices and the nature of their impact and influence. ${ }^{2}$

This study describes the attributes of foundations that enable them to play a significant role in addressing global challenges: financial independence, which enables foundations to take economic and political risks; the ability to move quickly or, conversely, to take the long view and provide patient capital; and the possibility of engaging directly with foreign societies and polities.

The study also examines representative foundation strategies in five areas: ${ }^{3}$

- improving global health, especially HIV/AIDS in Africa;

- alleviating poverty, particularly through agricultural development in Africa;

- protecting the environment and preventing climate change through advocacy;

- promoting democracy through support for education and civil society;

- improving global security including through private diplomacy.

Foundation efforts in these areas have been diverse and ambitious, including:

- creating new organizations to develop vaccines for developing countries and deliver anti-retroviral treatment in Africa;

- catalyzing a new Green Revolution in African agriculture;

- proposing and advocating laws and policies to address climate change and improve the prospects for an international climate agreement;

- supporting education and civil society organizations in Eastern Europe after 1989;

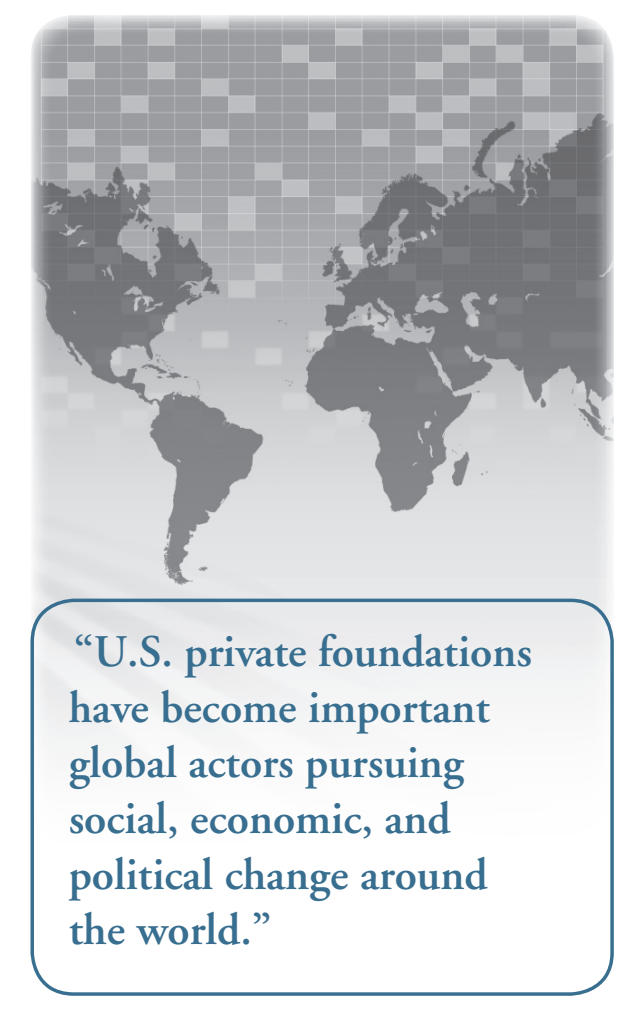


- pursuing private diplomacy with North Korea and Iran to address nuclear proliferation.

In examining the five global issue areas, the study also raises questions about foundation strategies. For example:

- Are programs sustainable in the longer term? Will governments, international organizations, or other private funders take on successful projects? Do foundations have exit strategies? Are they creating dependency relationships with their grantees?

- Do foundations understand the local foreign environment in which they are working and the ramifications of their interventions? Do they listen to local governments and partners? Do foundations create distortions in those environments?

- Are foundations efficient? Do they cooperate and coordinate with each other and with other funders to avoid waste and duplication?
The study goes on to examine three major issues regarding international funding:

- Whether and how to measure and evaluate the impact of international programs.

- The contributions of foundations to American influence and global governance, including the creation of new organizations, public-private partnerships, international networks, and development of new global rules and norms.

- The accountability of foundations at home and the problems of accountability abroad.

Finally, the study suggests new global challenges that foundations might address: the relationship between the U.S., the West and the complex and diverse Muslim world; preparing the United States for the new global world; and the relationship of American foundations with foundations originating outside the United States. 


\section{A SHORT HISTORY OF INTERNATIONAL PHILANTHROPY}

"While foundations
outside the United States
focused primarily on
serving their local area
or country, American
foundations have been
international from
the beginning."

\section{THE ORIGINS OF INTERNATIONAL PHILANTHROPY}

While philanthropy has roots in many cultures, the modern foundation grew out of the American experience. For many cultural and historical reasons, Americans-far more than Europeans, Japanese, or others-have looked to non-profit organizations or civil society, including foundations, to provide public services and to balance to the power of government and business. ${ }^{4}$ As a result, American public law and policy has encouraged non-profits and foundations while law and policy in other countries has been less favorable. ${ }^{5}$

The philanthropy of Andrew Carnegie and John D. Rockefeller, the fathers of today's private foundations, was motivated by the belief that private citizens and private wealth play an important and legitimate role in providing public welfare as well as by religious convictions and a desire to improve their public reputations. ${ }^{6}$ The objective of these early philanthropists was to use their fortunes to improve society by addressing the root causes of social ills such as poverty, hunger, and disease. In their view, charity addressed symptoms. Philanthropy sought to change the human condition by, for example, addressing inequities, improving health, and spurring education and research. This distinction between charity which seeks to alleviate suffering and philanthropy which is directed at social change remains a central feature of contemporary U.S. foundations. ${ }^{7}$
The idea of using vast private fortunes for public purposes has not been without controversy. From the earliest days, critics have challenged the motives, influence, and accountability of private foundations. At different times, Congressional and other critics have contended that foundations were tools of capitalism or vehicles of socialism, and Congress has passed laws to regulate their funding and increase their financial transparency. Yet foundations have become legitimate and widely accepted in American political culture and law. ${ }^{8}$ While they are subject to legal spending and disclosure requirements, foundations benefit from tax exemptions and are in practice only lightly regulated. As long as they avoid overtly political activities and support organizations and causes that serve the public good, foundation boards and staff by and large may choose how and where to spend their money.

While foundations outside the United States focused primarily on serving their local area or country, American foundations have been international from the beginning. ${ }^{10}$ Carnegie and Rockefeller, in particular, had strong international interests. Carnegie supported libraries and education in Scotland and the United Kingdom and established the Carnegie Endowment for International Peace to solve the problem of war. Rockefeller funded health and medical work as well as international education worldwide. Early on, U.S. foundations supported scientific and social science research at American and foreign universities and think tanks, established offices abroad, and engaged with American and foreign government officials. ${ }^{11}$ 


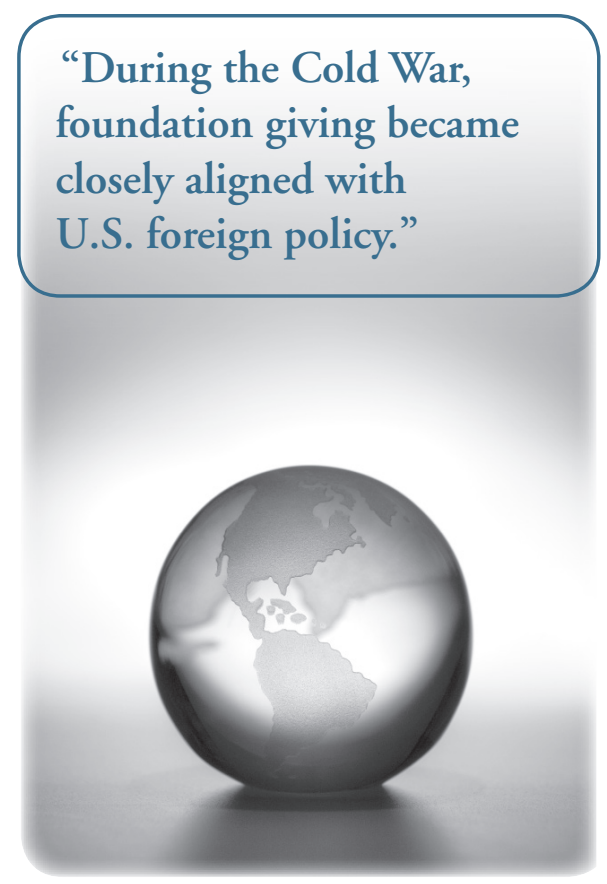

\section{PHILANTHROPY AND THE COLD WAR}

International philanthropy grew and changed after World War II and the onset of the Cold War. While reliable data on global philanthropy is not widely available prior to the 1980 s, more recent data suggests international giving by larger U.S. foundations rose from $\$ 75$ million in 1982 to more than $\$ 500$ million in 1990. (See Table 1). An increasing number of U.S. foundations joined Rockefeller and Carnegie on the international scene. The Ford and W.K. Kellogg foundations expanded into international programs; the Rockefeller Brothers Fund, created in 1940, and the John D. and Catherine T. MacArthur Foundation, which began making grants in 1979, adopted important international programs.

During the Cold War, foundation giving became closely aligned with U.S. foreign policy. Foundation leaders naturally responded to the international realities surrounding them especially the emergence of the United States as a world power; the devastation caused by the war in Europe and Japan; the Cold War; the end of colonial empires and the new importance of developing countries; and, later, détente and the desire to ease relations with the communist bloc.

The alignment of foundation policies with U.S. foreign policy also reflected close relationships between foundation and foreign policy leaders who knew each other and often moved from foundations to government and from government to foundations. John Foster Dulles, who became Secretary of State, was on the board of the Rockefeller Foundation; Dean Rusk was a State Department official before becoming president of the Rockefeller Foundation and then went on to become Secretary of State under Presidents Kennedy and Johnson; Paul Hoffman, who headed the Marshall Plan, became president of the Ford Foundation; Nelson Rockefeller, who became governor of New York and vice president of the United States, served as president of the Rockefeller Brothers Fund; and McGeorge Bundy served as President Kennedy's national security advisor before becoming president of the Ford Foundation. In addition to sharing a common world view, these public and private leaders sometimes worked together on initiatives, and government officials sometimes asked foundations leaders to pursue particular programs. ${ }^{12}$

The Gaither Report, commissioned to propose a new strategy for the Ford Foundation, reflected the new Cold War thinking of foundations. ${ }^{13} \mathrm{It}$ discussed the "tide of communism" in Asia and Europe and identified the threat to democracy around the world as the key challenge that the foundation should address. ${ }^{14}$ The report identified a number of possible national and international programs for the foundation including helping to develop informed American foreign

\section{TABLE 1 International Grants vs. All Grants for Sampled Foundations, 1982 to 2008 (dollars in thousands)}

\begin{tabular}{lrrr} 
Year & Int'l. Grants (Current) & $\begin{array}{c}\text { Int'l as \% } \\
\text { All Grants (Current) }\end{array}$ & \begin{tabular}{c} 
of All Grant Dollars \\
\hline $\mathbf{1 9 8 2}$
\end{tabular} $\mathbf{1 0 8}^{\mathbf{1 9 8 6}}$ \\
$\mathbf{1 9 9 0}$ & 178,214 & $\$ 1,490,246$ & 5.0 \\
$\mathbf{1 9 9 4}$ & 508,221 & $2,216,647$ & 8.0 \\
$\mathbf{1 9 9 8}$ & 679,433 & $4,405,808$ & 11.5 \\
$\mathbf{2 0 0 2}$ & $1,066,415$ & $5,930,302$ & 11.5 \\
$\mathbf{2 0 0 6}$ & $2,191,802$ & $9,786,685$ & 10.9 \\
$\mathbf{2 0 0 8}$ & $4,213,349$ & $15,884,818$ & 13.8 \\
\hline
\end{tabular}

Source: The Foundation Center, The Global Role of U.S. Foundations, 2010. Based on all grants of $\$ 10,000$ or more from a sample of approximately 1,000 larger U.S. foundations. 
policies, training leaders of "the highest competence and intellectual stature," promoting public understanding of those policies, and strengthening the United Nations. ${ }^{15}$ Noting the background of the Depression, the Gaither Report also emphasized the importance of strong economies "for the well-being of peoples throughout the world." 16

\section{Policies at Home}

Starting in the 1940s, American foundations launched major programs to prepare the United States for world leadership. Carnegie, Ford, and Rockefeller helped establish and sustain foreign policy, area, and language studies at numerous American universities; and they funded fellowships for international travel and training. Building on their earlier support for the social sciences, foundations also funded policy research institutions addressing foreign and national security policy and economic development. ${ }^{17}$ Abroad, foundations promoted democratic and free market-oriented elites and encouraged ties between the U.S. and the leaders of both developed and developing countries.

\section{Japan and Europe}

Immediately after the war, the Rockefeller and Carnegie foundations resumed their prewar activities in international exchange and global health. Excluded from the nowcommunist areas in China and Eastern Europe where they had been active, they focused on Japan and Europe. In 1951, when John Foster Dulles was the principal negotiator of the peace treaty between the United States and Japan, he asked John D. Rockefeller III to join him on a mission to Japan to study and make recommendations about what private philanthropy could do to establish close relations between the U.S. and Japan. Dulles, the future Secretary of State and member of the board of the Rockefeller Foundation, wanted to use education and private cultural diplomacy to build proWestern elites in Japan and establish strong bilateral relations between the two countries, and he wanted Rockefeller to help.

The Rockefeller visit led to significant foundation programs that supported Japanese universities, civil society organizations, and scholars, as well as conferences and exchanges between the U.S. and Japan. These programs continued well into the 1970s and were supported by Rockefeller personally, as well as by the Rockefeller, Carnegie, and Ford foundations. The funding helped shape the democratic and free market orientation of Japan's intellectual and political elites, and contributed to close relations between the two countries. ${ }^{18}$

Rebuilding democratic elites in Europe and assuring close transatlantic ties was also a concern. As the U.S. government helped rebuild the economic infrastructure of Europe through the Marshall Plan, foundations focused on rebuilding the human infrastructure. Immediately after the war, the Rockefeller Foundation provided emergency funding for universities, libraries, and research centers in the natural sciences, medicine, the humanities, and social sciences. This support enabled institutions to buy equipment and supplies, rebuild libraries, organize conferences, and help scholars generally "pick up the threads of their research." 19 Throughout the Cold War, American foundations financed exchanges among leaders on both sides of the Atlantic in order to build enduring

transatlantic networks. ${ }^{20}$

\section{Developing Countries}

Foundations began to support economic development in poor countries long before Western governments and international organizations. The work was led initially by Rockefeller, which had been involved in developing countries

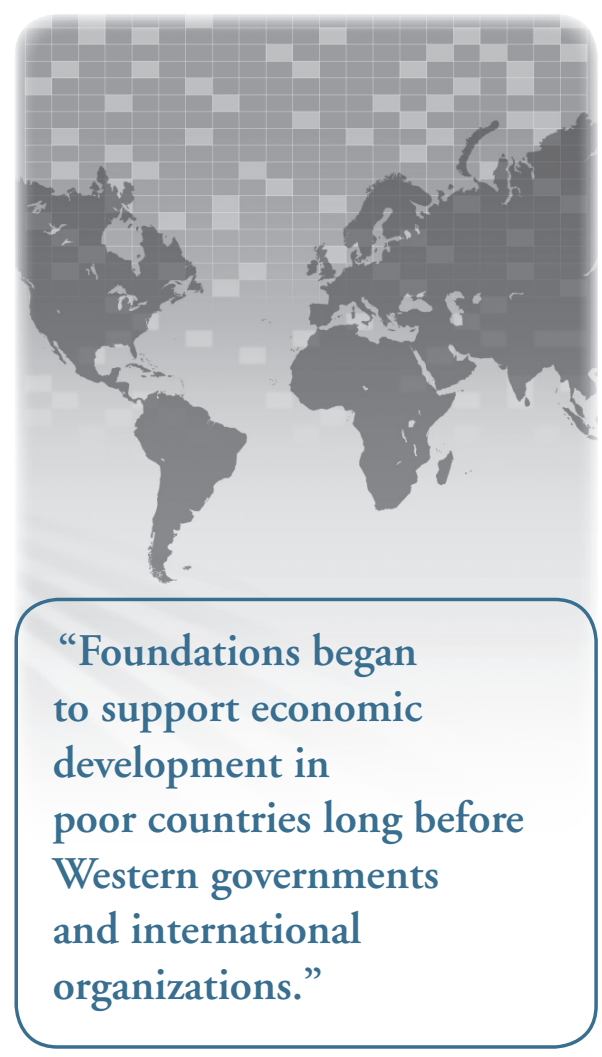




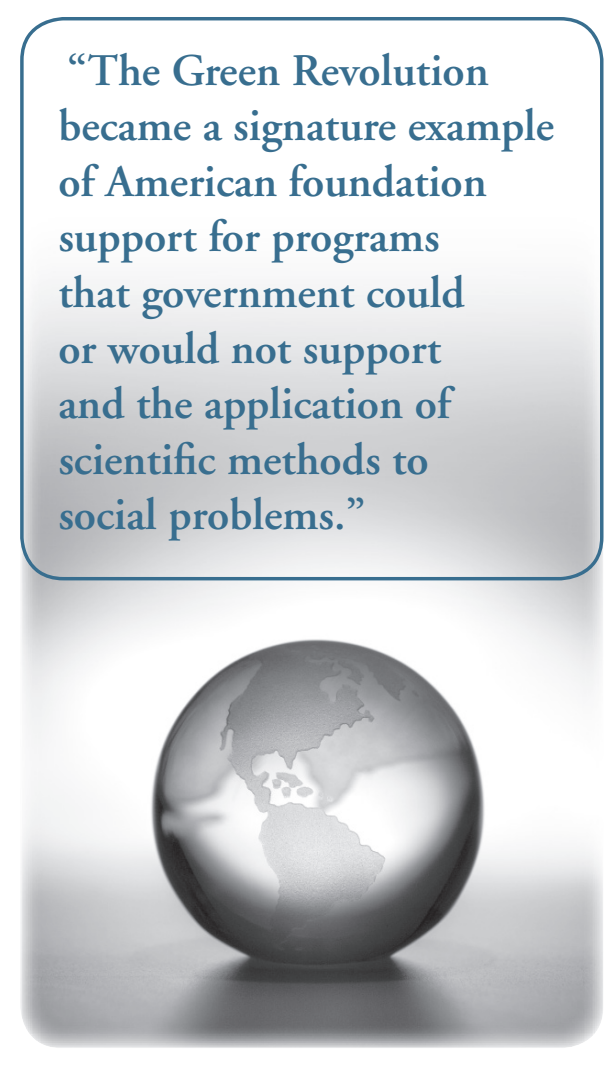

“The Green Revolution

became a signature example

of American foundation

support for programs

that government could

or would not support

and the application of

scientific methods to

social problems." almost since its inception, and joined later most importantly by the Ford Foundation which became a major funder in developing countries during the Cold War. Underlying foundation strategies were academic studies of economic development and political modernization that foundations like Carnegie and Rockefeller had started funding in the 1920s and 30s. Those studies reasoned that economic development proceeded in stages and could be accelerated by applying certain missing factors of production: financial capital, technology, and skilled human capital. According to the prevailing theories, economic development, in turn, would lead to political stability and democracy. ${ }^{21}$

The most significant foundation program was the Green Revolution. It began in 1941, when Vice President Henry Wallace told the President of Rockefeller Foundation about the severe problems of nutrition and agriculture in Mexico and suggested that an improvement in crop yields would be the single most effective contribution to that country's welfare. In 1943, the Rockefeller Foundation and Mexico's Department of Agriculture signed an agreement for a program to modernize Mexican agriculture that would be run by the foundation. In the ensuing years, Rockefeller and Mexican scientists developed new high-yield varieties of corn, wheat, and other crops; designed new farming methods including the use of fertilizers, insecticides, and irrigation; took new seeds and practices into the field; and trained Mexican agronomists and other professionals to carry on the work. ${ }^{22}$

Over the coming decades, the Ford and Kellogg foundations became supporters of the Green Revolution as it expanded to Latin America, Asia, and Africa. Foundations financed research, development, and implementation of new seeds, irrigation, and pesticides that dramatically increased agricultural production in Asia and Latin America.
The Green Revolution became a signature example of American foundation support for programs that government could or would not support and the application of scientific methods to social problems. The Revolution was criticized later for its technological approach—including the emphasis on chemical fertilizers and pesticides that were potential health hazards; its energy intensive and irrigation-based farming methods that can strain water supplies; the focus on high yield varieties of crops that threaten to reduce biodiversity and food quality —as well as for its failure to help the poorest farmers. Nevertheless, it transformed agriculture, dramatically increased food production, and thereby influenced the economies, societies and polities of many countries in Asia and Latin America. ${ }^{23}$

Foundations also became involved in population programs in developing countries, issues that governments hesitated to fund. Initial foundation work on population grew out of the Rockefeller Foundation's role in public health and medicine, as well as its support for social sciences and population studies. As early as the late 1940s, studies sponsored by Rockefeller had identified the need to address rapid population growth in developing countries, but the foundation initially hesitated to take on an issue that was politically, socially, and culturally sensitive. So, in 1952, John D. Rockefeller III established and provided initial funding for the Population Council, which in turn supported research, training, and technical assistance worldwide on population science, methods, and policies. The Rockefeller and Ford Foundations and the Rockefeller Brothers Fund began providing financing soon thereafter. The Population Council went on to fund fellowships and training for demographers, establish regional scientific research centers, and provide technical assistance on population 
issues to international organizations and governments throughout the developing world. ${ }^{24}$

Foundations also invested broadly in human capital in developing countries to support economic development and promote effective government. They funded education and training of scholars, teachers, economists, agronomists, and public officials and established universities and research centers in developing countries. Foundations also provided technical assistance in the form of expatriate experts such as agronomists and demographers who worked in or closely with developing country governments. These programs began in India and Latin American and expanded to include African countries as they became independent in the late 1950 s. $^{25}$

While the work of foundations in developing countries complemented and aligned with U.S. government policies during the Cold War, foundations were also willing to diverge to some degree from government policy on certain issues. One was human rights. Following military coups and the installation of repressive military regimes in Latin America in the 1970s, the U.S. government continued to support these anticommunist governments. Foundations, however, protected threatened scholars and intellectuals, supported individuals who challenged repressive practices, and funded human rights organizations that monitored, documented and publicized human rights abuses. ${ }^{26}$

Foundations also helped challenge the apartheid regime in South Africa at a time when U.S. government policy supported South Africa as a bulwark against communism, opposed U.N. resolutions calling for sanctions against the regime, and pursued "constructive engagement" with South Africa. Starting in the 1970s, Carnegie, Ford, and the Rockefeller Brothers Fund funded academic institutions and civil society organizations in
South Africa engaged in public interest law projects to challenge apartheid policies in the courts. Foundation supported organizations including the Centre for Applied Legal Studies and the Legal Resources Center or LRC at the University of Witwatersrand conducted research, brought court cases, publicized repressive practices, and advocated against discriminatory practices with regulatory and administrative authorities. Another South African grantee, the Southern Africa Legal Services Foundation, directed financial and other resources to the LRC and other organizations that advocated for basic human rights through the courts system. Foundations also supported South African legal aid clinics based at law schools to train public interest law students and black legal professionals and to provide legal advice to individuals. ${ }^{27}$ Other American foundations including Kellogg and Mott, funded civil society organizations at the community level to provide services and strengthen civil society in South Africa. ${ }^{28}$

\section{Communist Bloc}

While foundations were active in China and Eastern Europe from the early days, they could not operate in these countries during World War II and the Cold War. Foundations did, however, support several limited efforts to reach into the communist bloc. Starting in the 1960s, the Ford Foundation funded an organization that provided Eastern European intellectuals with books and journals as well as grants for travel to Western Europe. ${ }^{29}$ A number of foundations supported the International Research and Exchanges Board (IREX) which arranged academic exchanges between Eastern and Western scholars. Ford and other foundations also financed a series of meetings between U.S. and Soviet citizens that began in 1960 at the height of the Cold War and were known as the Dartmouth Conferences. But it was not until

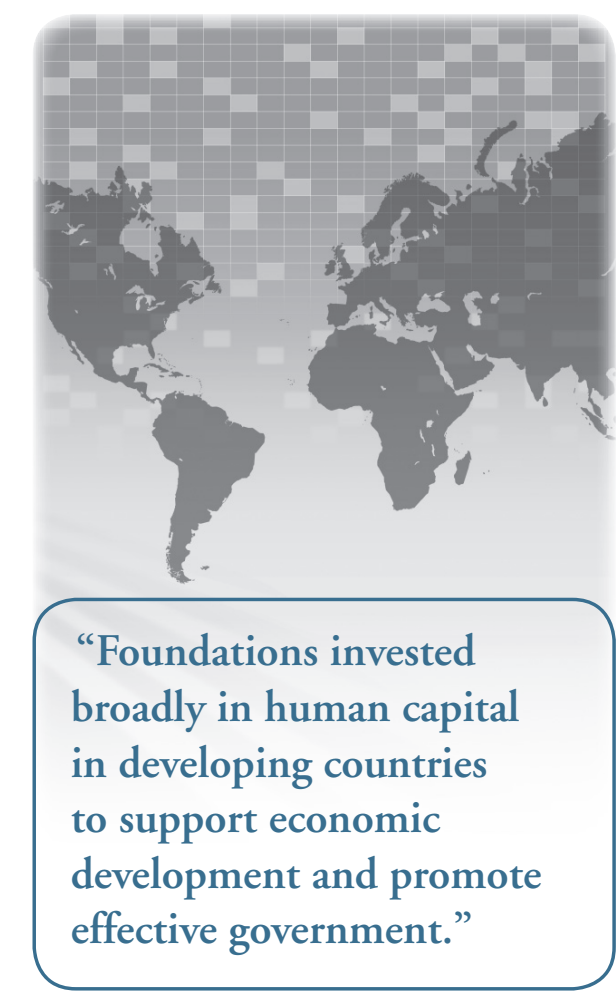

"Foundations invested broadly in human capital in developing countries to support economic development and promote effective government." 
the era of détente in the 1970s and 1980s that foundations created significant programs directed at communist countries.

In the 1970s, foundations began to support dissidents, human rights activists, and civil society groups in Eastern Europe. In 1978, Ford launched an organization to advance human rights issues behind the Iron Curtain. The foundation's involvement was influenced by Arthur Goldberg, former Supreme Court justice and former U.S. ambassador to the United Nations, who headed the U.S. delegation to the Conference on Security and Cooperation in Europe in 1977. Goldberg returned from that international meeting concerned that the United States and Western governments were not responding to human rights advocates then emerging in the Eastern bloc and asked McGeorge Bundy, president of the Ford Foundation, to help. Ford responded by creating, funding and initially staffing U.S. Helsinki Watch which established links with groups in the Soviet Union and Eastern Europe, publicized human rights abuses behind the Iron Curtain, and lobbied Western governments to address human rights violations in intergovernmental forums. In 1990, after the fall of communist regimes in Europe, US Helsinki Watch became Human Rights Watch, which continues to advocate for human rights around the world. ${ }^{30}$ George Soros, a refugee from Hungary, began his extensive philanthropic support for dissidents in Eastern Europe in the 1980s. Soros foundations gave unauthorized publications to Eastern European intellectuals and provided financial support to dissident groups such as the Polish labor union, Solidarity, and the Czech human rights group, Charter $77 .{ }^{31}$

In the early 1980s, U.S.-Soviet relations hardened after the Soviet invasion of Afghanistan and the election of President Ronald Reagan.
Some foundation leaders, concerned about growing dangers of nuclear war, began to fund studies about managing East-West tensions, improving relations between the U.S. and the Soviet Union, and preventing nuclear war. For example, in 1983, Carnegie established a program on security and conflict resolution that made grants to study how nuclear war might erupt and to devise techniques for preventing crises and the use of nuclear weapons. In 1984, the new MacArthur Foundation launched a program on International Peace and Security to address the threat from nuclear weapons and the U.S. Soviet strategic rivalry. At the same time, the C.S. Mott Foundation committed its first major international funding programs to security and arms control.

After Mikhail Gorbachev became the Secretary General of the Communist Party in 1985, the prospects for détente improved. At this point, some foundations began to fund meetings of scientists, academics, and experts on both sides of the Iron Curtain as a way to bridge the gaps and build mutual trust and understanding. Carnegie worked with the U.S.

National Academy of Sciences and the Soviet Academy of Sciences to organize meetings of scientists to study arms control, crisis prevention, conflict resolution, and third world flashpoints that might trigger massive conflict. Starting in the early 1980s, Carnegie also sponsored meetings under the auspices of the Aspen Institute, beginning with members of Congress and American experts and later including European parliamentarians and members of the Russian Duma. Still later, meetings were organized between U.S. and Soviet military leaders. Eventually, Carnegie's work on such informal diplomacy led to a two-year private dialogue between Dr. David Hamburg, the President of the Carnegie Corporation, and Gorbachev which helped build bridges between Gorbachev and the Reagan Administration. ${ }^{32}$
Thus, throughout the Cold War era, American foundations complemented and, for the most part, aligned with U.S. foreign policy. The money spent by foundations on international programs was dwarfed by official expenditures, but foundations carved out a role appropriate for private funding. They helped develop the talent and ideas at home for engagement abroad, fostered ties between Americans and elites around the world, and in so doing promoted American values including democracy, human rights, and free markets. Foundation investments in human capital in war torn Western Europe and Japan complemented funding for physical capital from governments and international organizations. In the days before significant U.S. and other foreign assistance flowed to the developing world, foundations supported economic development and educational programs that helped shape the economies and leadership in those countries. And, as the Cold War drew to a close, foundations helped build human bridges to the communist bloc.

Experts have debated the significance of this close alignment between foundations and U.S. foreign policy. Critics on the left have seen this alignment as part of American global hegemony. ${ }^{33}$ Critics on the right have argued that foundations have promoted "globalism" instead of fulfilling their responsibility to support the "core institutions of American democracy". ${ }^{34} \mathrm{~A}$ more realistic view is that foundations reflected the world view of the American foreign policy elite during the Cold War and sought, in their international grant programs, to advance American values of pluralist democracy, liberal economies, and close ties with the United States. 


\section{GLOBAL PHILANTHROPY IN THE POST-COLD WAR ERA}

\section{"International giving by} the largest U.S. foundations rose from $\$ 680$ million in 1994 to $\$ 6.2$ billion by $2008 . "$
THE GROWTH OF INTERNATIONAL FUNDING

In the last two decades, the international work of foundations has been transformed again. A surging American economy and stock market enriched existing foundations and led to the creation of new wealth and new philanthropies. Between 1990 and 2008, foundation assets increased almost fourfold from $\$ 143$ billion to $\$ 565$ billion. (See Figure 1) Overall foundation giving quintupled from $\$ 8.7$ billion in 1990 to $\$ 46.8$ billion in 2008. (See Figure 2) The number of American foundations more than doubled, from about 32,000 in 1990 to over 75,000 in $2008 .^{35}$

The growth of international funding has also been driven by a new world order. The Cold War ended and former communist nations sought to join the West and become democracies and market economies. Many developing countries elected democratic governments, opened their markets, and joined the global economy. Other countries and social groups, however,

\section{FIGURE 1 Total U.S. Foundation Assets, 1990 to 2008}

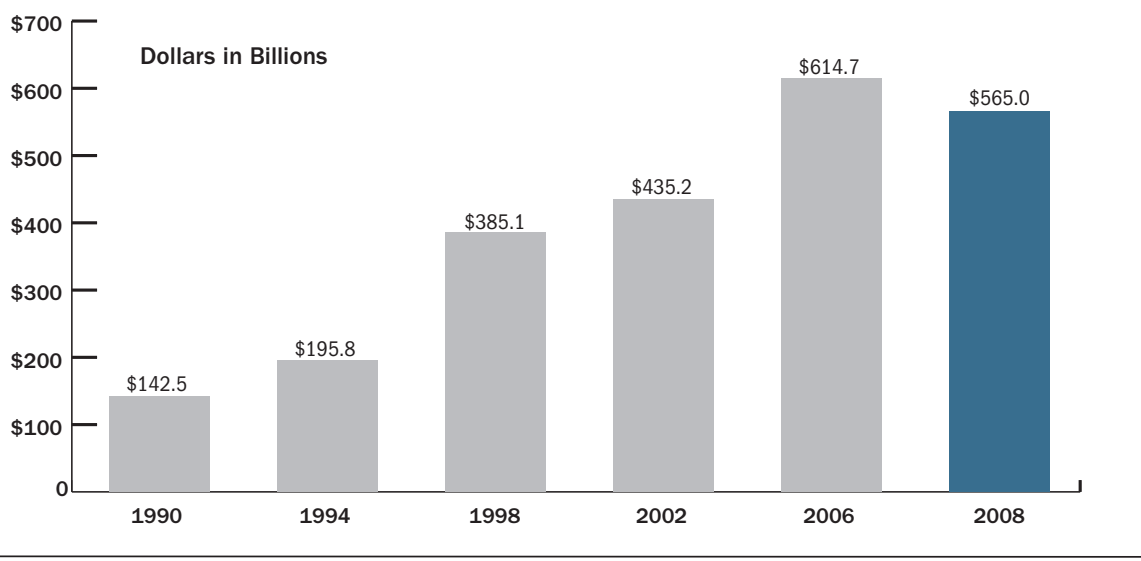

Source: The Foundation Center, The Global Role of U.S. Foundations, 2010.

\section{FIGURE 2 Total U.S. Foundation Giving, 1990 to 2008}

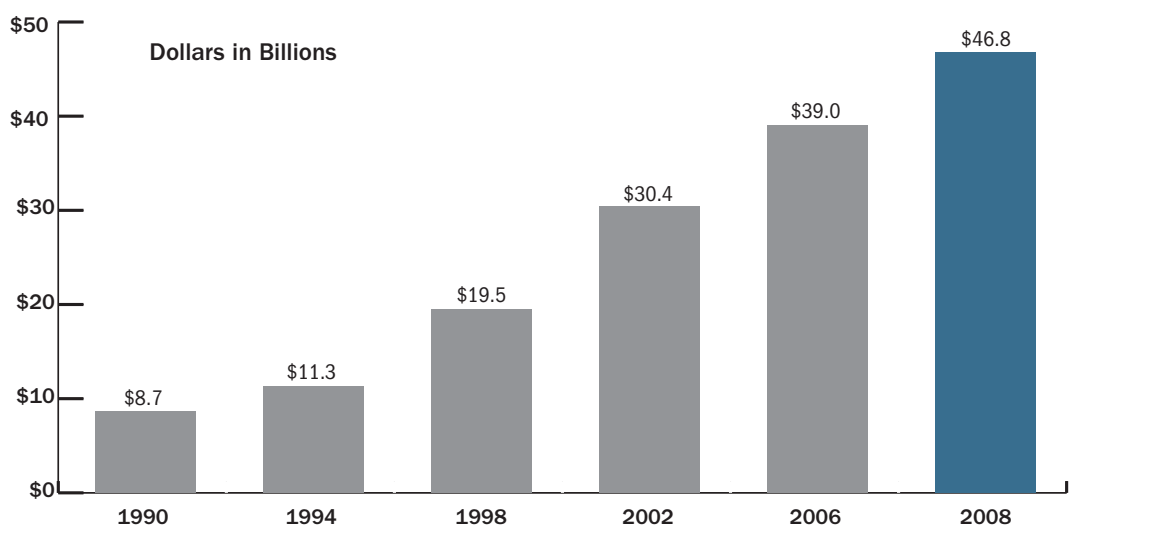

Source: The Foundation Center, The Global Role of U.S. Foundations, 2010. 
remained marginalized, undemocratic, and mired in poverty. New global problems such as health, environmental preservation, climate change, and nuclear proliferation emerged as global threats. With the growing interdependence of economies, polities, and societies, and with instantaneous communication, foundation leaders, like the rest of society, became more aware of the global nature of the human condition and of these concerns. So it has been natural for foundations to try to address the root causes of problems at a global level, both in and outside the United States.

Established foundations active in international funding came to see grant making through the lens of globalization. For example, the 1993

\section{FIGURE 3 Growth of Overseas vs. U.S.-Based International Giving, 2002 to 2008}

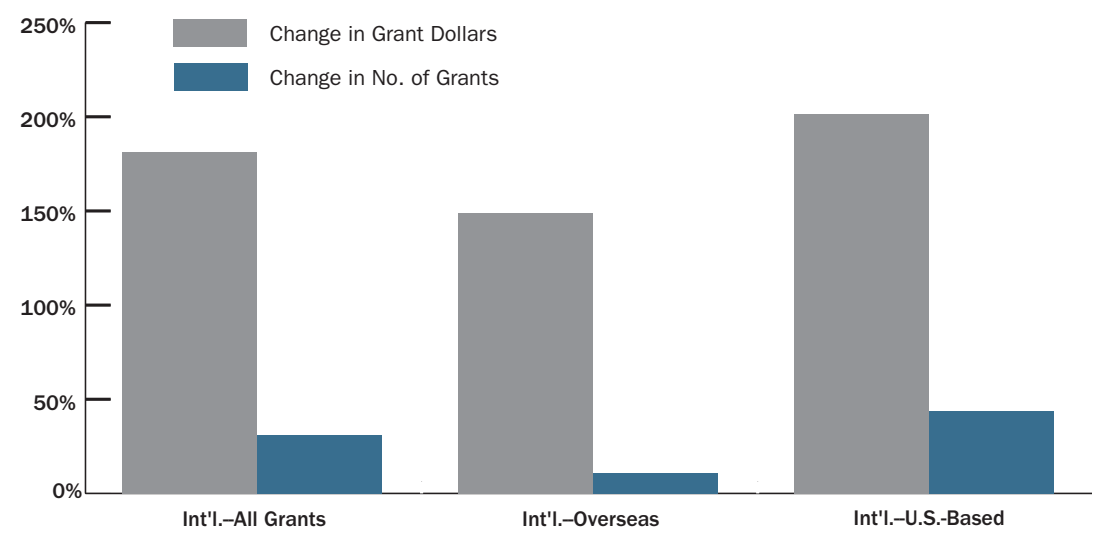

Source: The Foundation Center, The Global Role of U.S. Foundations, 2010. Based on all grants of $\$ 10,000$ or more from a sample of approximately 1,000 larger foundations.

\section{FIGURE 4 International Giving as a Share of Overall Foundation Giving,} 1982 to 2008

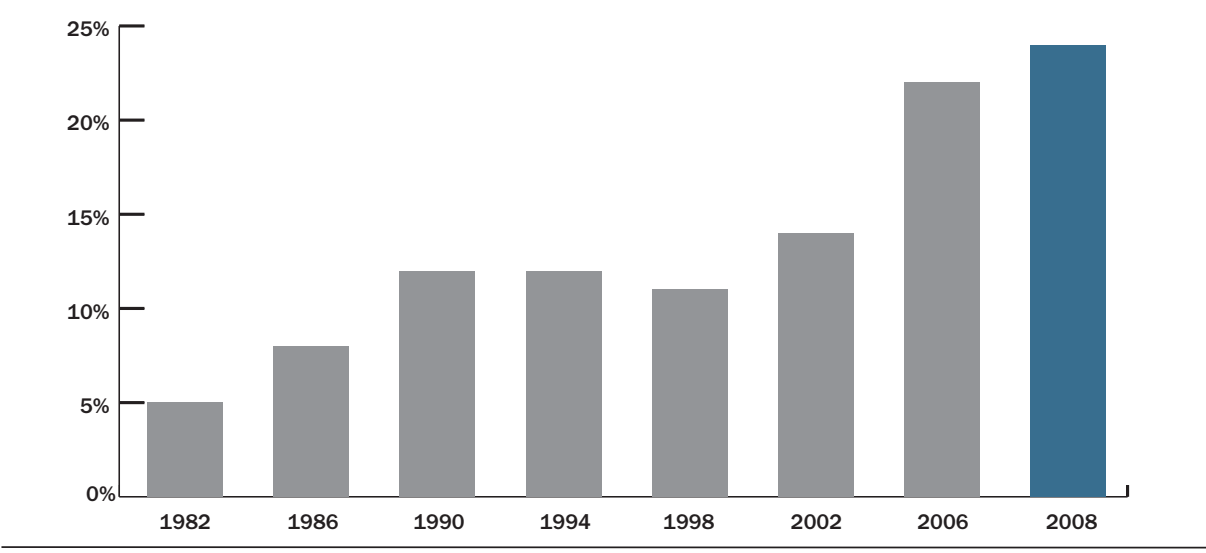

Source: The Foundation Center, The Global Role of U.S. Foundations, 2010. Based on all grants of $\$ 10,000$ or more from a sample of approximately 1,000 larger foundations. annual report of the MacArthur Foundation stated that: "The building of adequate mechanisms for global governance has become a defining challenge for the present generation." ${ }^{36}$ A Rockefeller Foundation report later put it this way: "Globalization is the major trend of our time, the foremost driver of change in the world today, with consequences both beneficial and burdensome. The Rockefeller Foundation attempts to harness the creative forces of globalization, supporting breakthrough solutions to 21 st century challenges." ${ }^{37}$

The 1980s and 1990s also saw the creation of new foundations based on fortunes in technology, media, and finance. Some living philanthropists including Bill Gates and George Soros founded global businesses, operated in global markets, and quite naturally saw their philanthropy in global terms. Bill and Melinda Gates said that their philanthropy was inspired by an article on children dying in poor countries from diseases that had long been eliminated in the United States and that their foundation is based on the belief that technological advances make it possible to solve large, complicated problems as never before in history. ${ }^{38}$ George Soros, born in Hungary, started his philanthropy by fostering "open societies" in Eastern Europe in the 1980s and, in 1994, established the Open Society Institute "to build vibrant and tolerant democracies whose governments are accountable to their citizens." 39 Other established foundations, including Hewlett and Packard, were enriched at the death of their benefactors and began to direct significant new resources to global programs. ${ }^{40}$ With the expected creation of other new philanthropies and the significant addition to the Gates Foundation by Warren Buffett in the coming years, there will likely be even greater attention to international philanthropy. ${ }^{41}$

As a result of all these forces, international funding by U.S. foundations - including funding for 
overseas recipients and funding for U.S.-based international programshas grown significantly. International giving by the largest U.S. foundations rose from $\$ 680$ million in 1994 to $\$ 2.2$ billion in 2002 and, by 2008 , reached $\$ 6.2$ billion. That $\$ 6.2$ billion is even more significant when compared with total U.S. government overseas development assistance in 2008, which was $\$ 26$ billion. ${ }^{42}$ Both overseas giving and U.S.-based international giving grew significantly. (See Figure 3.) The growth of global philanthropy has outpaced the growth of domestic funding, and now represents 24 percent of all grants by major U.S. foundations. (See Figure 4.)

Although large foundations account for 86 percent of international grant dollars, many smaller foundations have become involved. And in recent years, international grants by community and corporate foundations have grown faster than international grants by private foundations. New foundations created since 1990, both large and small, now represent 56 percent of international funding. (See Figure 5) Several new mega foundations now account for a significant portion of international grant dollars. In 2008, for example, the Gates Foundation alone accounted for 44 percent of international giving. (See Table 2$)^{43}$

In geographical terms, the largest share of both U.S.-based and overseas funding-about 65 percent-goes directly or indirectly to developing countries, particularly to sub-Saharan Africa. A significant portion of overseas funding going to developing countries has flowed through Europe, particularly to health organizations

\section{TABLE 2 Top 25 Foundations by Amount of International Giving, 2008}

\begin{tabular}{|c|c|c|c|c|c|c|c|}
\hline Foundation & $\begin{array}{l}\text { Foundation } \\
\text { State }\end{array}$ & $\begin{array}{l}\text { Fdn. } \\
\text { Type }^{1}\end{array}$ & $\begin{array}{l}\text { No. of Intl. } \\
\text { Grants }\end{array}$ & $\begin{array}{l}\text { Amount of Intl. } \\
\text { Grants }\end{array}$ & $\begin{array}{l}\% \text { of Total } \\
\text { Intl. Grants }\end{array}$ & $\begin{array}{l}\% \text { Change in Intl. } \\
\text { Giving '04 to '08 }\end{array}$ & $\begin{array}{l}\text { Intl. as a \% of } \\
\text { All Giving }\end{array}$ \\
\hline 1. Bill \& Melinda Gates Foundation & WA & IN & 526 & $\$ 2,741,720,975$ & 44.4 & 122.3 & 86.4 \\
\hline 2. William and Flora Hewlett Foundation & $\mathrm{CA}$ & IN & 246 & $622,874,631$ & 10.1 & $1,000.6$ & 79.5 \\
\hline 3. Ford Foundation & NY & IN & 1233 & $282,366,082$ & 4.6 & 9.2 & 52.4 \\
\hline 4. Susan Thompson Buffett Foundation & $\mathrm{NE}$ & IN & 60 & $186,991,109$ & 3.0 & $1,926.1$ & 53.8 \\
\hline 5. David and Lucile Packard Foundation & $\mathrm{CA}$ & IN & 254 & $122,831,562$ & 2.0 & 210.6 & 37.5 \\
\hline 6. Gordon and Betty Moore Foundation & $\mathrm{CA}$ & IN & 119 & $115,376,014$ & 1.9 & 150.8 & 39.9 \\
\hline $\begin{array}{l}\text { 7. John D. and Catherine T. MacArthur } \\
\text { Foundation }\end{array}$ & IL & IN & 298 & $102,480,230$ & 1.7 & 40.1 & 47.0 \\
\hline 8. Rockefeller Foundation & NY & IN & 181 & $78,012,342$ & 1.3 & 7.9 & 58.3 \\
\hline 9. Andrew W. Mellon Foundation & NY & IN & 155 & $60,618,900$ & 1.0 & 60.6 & 22.0 \\
\hline 10. Carnegie Corporation of New York & NY & IN & 132 & $58,329,716$ & 0.9 & 37.5 & 44.8 \\
\hline 11. Turner Global Foundation & GA & IN & 2 & $50,000,000$ & 0.8 & $1,237.8$ & 100.0 \\
\hline 12. Lincy Foundation & $\mathrm{CA}$ & IN & 22 & $49,858,168$ & 0.8 & 99.1 & 29.1 \\
\hline 13. Silicon Valley Community Foundation & $\mathrm{CA}$ & $\mathrm{CM}$ & 414 & $45,702,876$ & 0.7 & $1,351.6$ & 21.3 \\
\hline 14. Howard G. Buffett Foundation & IL & IN & 40 & $38,288,239$ & 0.6 & -- & 87.2 \\
\hline 15. Citi Foundation & NY & $\mathrm{CS}$ & 483 & $37,971,000$ & 0.6 & 67.7 & 44.4 \\
\hline 16. AVI CHAI Foundation & NY & IN & 25 & $37,508,528$ & 0.6 & 82.3 & 83.6 \\
\hline 17. Bloomberg Family Foundation & NY & IN & 2 & $36,250,000$ & 0.6 & 504.2 & 100.0 \\
\hline 18. W. K. Kellogg Foundation & $\mathrm{Ml}$ & IN & 180 & $35,450,361$ & 0.6 & $(37.1)$ & 18.5 \\
\hline 19. Danforth Foundation & MO & IN & 2 & $33,030,765$ & 0.5 & 115.1 & 85.2 \\
\hline 20. Freeman Foundation & NY & IN & 132 & $31,411,545$ & 0.5 & $(41.2)$ & 70.6 \\
\hline 21. Annenberg Foundation & $\mathrm{CA}$ & IN & 118 & $30,976,383$ & 0.5 & 133.4 & 11.6 \\
\hline $\begin{array}{l}\text { 22. Harry and Jeanette Weinberg } \\
\text { Foundation }\end{array}$ & MD & IN & 135 & $30,785,282$ & 0.5 & 34.2 & 31.2 \\
\hline 23. New York Community Trust & NY & $\mathrm{CM}$ & 228 & $29,488,321$ & 0.5 & 200.2 & 20.6 \\
\hline 24. Walton Family Foundation & AR & IN & 11 & $28,963,987$ & 0.5 & $1,170.2$ & 14.3 \\
\hline 25. Charles Stewart Mott Foundation & $\mathrm{MI}$ & IN & 192 & $27,379,670$ & 0.4 & 8.0 & 27.4 \\
\hline Subtotal & & & 5,190 & $\$ 4,914,666,686$ & 79.6 & & \\
\hline All other foundations & & & 9,719 & $1,260,450,093$ & 20.4 & & \\
\hline Total & & & 14,909 & $\$ 6,175,116,779$ & 100.0 & & \\
\hline
\end{tabular}

Source: The Foundation Center, The Global Role of U.S. Foundations, 2010. Based on all grants of $\$ 10,000$ or more from each foundation; excludes operating program expenses and grants to individuals.

${ }^{1} \mathrm{IN}=$ Independent Foundation; $\mathrm{CM}=$ Community Foundation; $\mathrm{CS}=$ Corporate Foundation.

$-=$ Not available. 
working in Africa and other poor countries. (See Figures 6 and 7) The largest amount of money and greatest growth of funding has been for health and development, a significant share of which came from the Gates Foundation, followed by environmental programs. (See Figure 8)

Foundations old and new are a diverse group. They bring their varied histories; world views; economic, social, and political persuasions; and personal perspectives to their philanthropy. Thus, the international policies and programs of foundations vary widely, reflecting the different views of their benefactors, boards, and staff as well as the resources at their disposal. Nevertheless, foundation funding has coalesced around several major global challenges: enhancing global health; encouraging economic development and the alleviation of poverty; protecting the environment and preventing climate change; promoting democracy and civil society; and improving global security. A review of foundation work in each of these areas sheds light on the strategies and methods of global philanthropy.

\section{GLOBAL CHALLENGE: HEALTH DISPARITIES}

The health problems of developing countries have emerged as a major global challenge of the twenty first century. Access to healthcare is limited or non-existent for most people in developing countries, while research on and development of treatments for diseases of the developing world have been inadequate at best. In the late twentieth century, governments and international organizations became increasingly aware of health in developing countries as a global issue. With the rapid spread of HIV/ AIDS and other epidemics like SARS, developed countries recognized their vulnerability to the spread of infectious diseases originating in developing countries. As HIV/AIDS, malaria, tuberculosis, and other diseases weakened developing country societies and governments, foreign policy leaders also came to see health disparities as an impediment to economic development and a threat to global security. ${ }^{44}$

Foundations were pioneers in global health. In the early part of the twentieth century, the Rockefeller Foundation helped improve medical education and research and supported public health programs in the United States and around the world. After the Second World War, as governments began to assume responsibility for public health, foundations including Rockefeller stepped back from funding medical and public health programs. ${ }^{45}$ Today, health has become the largest category of international funding by U.S. foundations, accounting for 39 percent of international giving in 2008.

\section{FIGURE 5 Profile of International Funders in 2008}

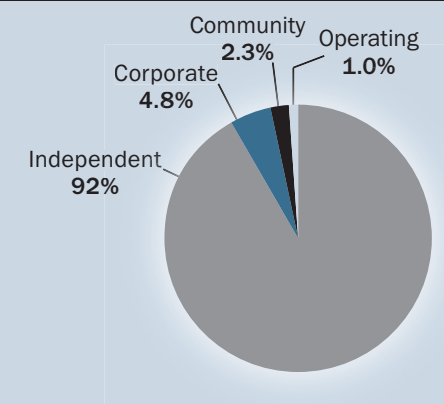

Type of Foundations

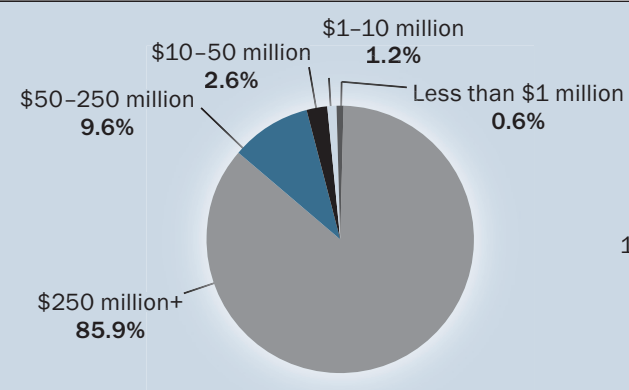

Asset Size

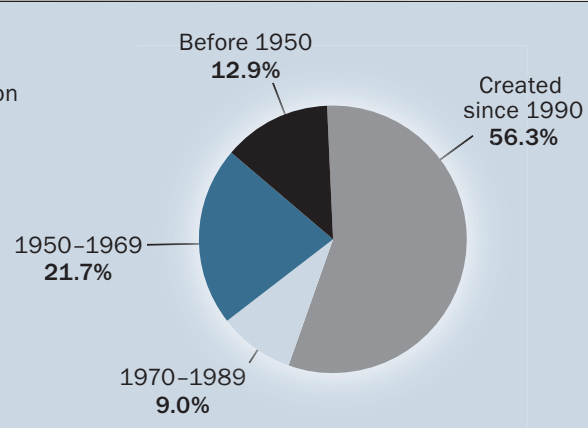

Period of Creation

Percent of Grant Dollars 


\section{The HIV/AIDS Crisis}

A significant share of that funding goes to address the HIV/AIDS pandemic in developing countries. American foundations were among the early funders of research, treatment, and public education about the epidemic in the United States. Changing public attitudes and advocacy, along with foundation support, contributed to increased U.S. government and pharmaceutical funding for research, greater attention to prevention, more options for treatment, and better overall management of the epidemic in the U.S.

As conditions in the U.S. improved and as knowledge and awareness of the global scope of the pandemic grew, many American foundations shifted their attention to the AIDS crisis in the developing world, especially in Africa. In absolute dollars, the Bill and Melinda Gates Foundation has been the dominant player in international health and HIV/AIDS, although it is far from the only foundation addressing the pandemic in developing countries. (See Table 3) Foundations have pursued several principal strategies on HIV/AIDS. A few including Gates and Rockefeller have funded drug and vaccine research; others including

\section{FIGURE 6 Overseas Giving by Major Region, 2008}

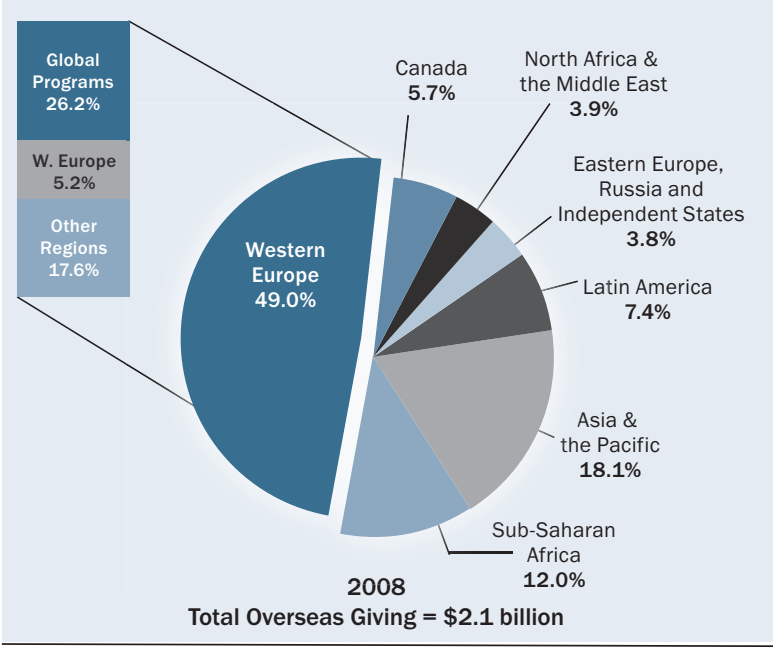

Source: The Foundation Center, The Global Role of U.S. Foundations, 2010. Based on all grants of $\$ 10,000$ or more from a sample of approximately 1,000 larger foundations. Grants to overseas recipients may be for programs conducted in other countries or regions.
Gates have financed programs for the delivery of AIDS treatments; still others such as the Doris Duke Charitable Foundation support clinical research on HIV/AIDS and research on health systems; the Ford Foundation among others funds civil society organizations that advocate on behalf of people living with AIDS; and many foundation programs, including Rockefeller's program on using mobile devices to promote health, now include public education about HIV/AIDS prevention.

Because the cost of health care programs is so great and health care delivery in low resources settings is so complicated, foundations have frequently tried to leverage their funding, expertise, and influence through a variety of international public-private partnerships. Publicprivate partnerships are of many types,

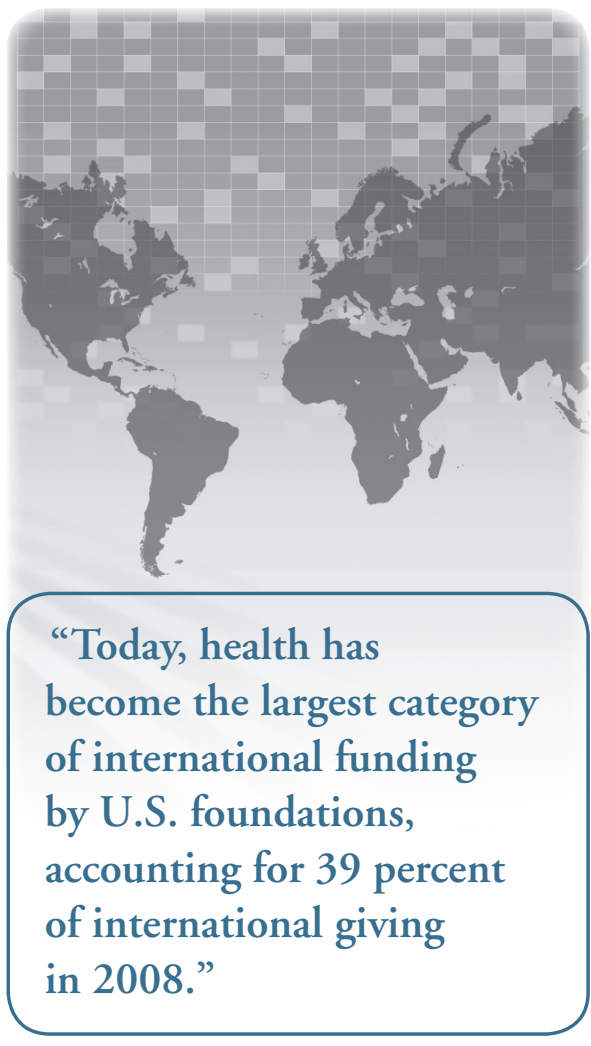
ranging from cooperation in funding to establishment of organizations at a national or regional level to creation of multilateral transnational organizations. They may include various combinations of private

\section{FIGURE 7 Giving to U.S.-Based International Programs by Major Region, 2002, 2006, and 2008}

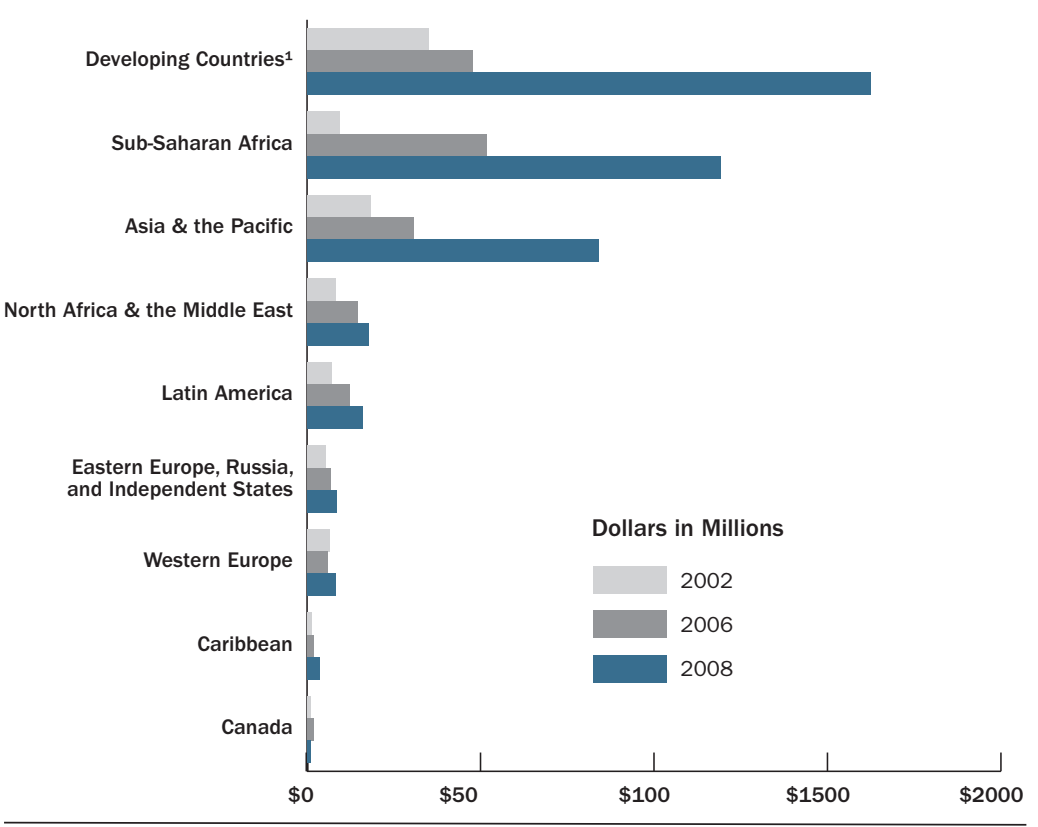

Source: The Foundation Center, The Global Role of U.S. Foundations, 2010. Based on all grants of $\$ 10,000$ or more from a sample of approximately 1,000 larger foundations. Grants may occasionally benefit more than one region and would therefore be counted more than once.

${ }^{1}$ Programs aimed broadly at developing countries. 


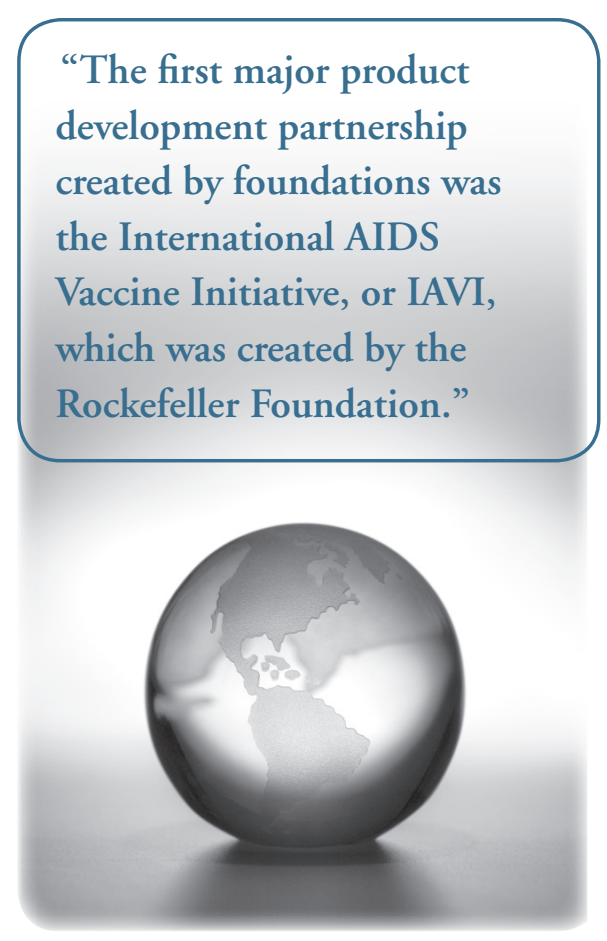

foundations, non-governmental or non-profit organizations, private corporations, governments, and multilateral organizations. HIV/AIDS has become a major area of new publicprivate partnerships organizations to address the global pandemic.

Foundations have formed several partnerships to conduct research and develop treatments for diseases prevalent in poor countries including malaria, TB, and HIV/AIDS. In the developed world, drug research and development is driven by private companies motivated by profit incentives. By and large, pharmaceutical firms in both the developed and developing world have not focused their resources on diseases of and drugs for the developing world where markets are not seen as profitable. Several international partnerships of foundations, companies, governments, and international organizations have used public private partnerships to address that gap in research and marketing of treatments in poor countries.

The first major product development partnership created by foundations was the International AIDS Vaccine Initiative, or IAVI, which was created by the Rockefeller Foundation. ${ }^{46}$ By the 1990s, early hopes for the development of an AIDS vaccine had diminished, and experts became concerned that even if a vaccine were developed it would be based on the subtype of the disease prevalent in developed countries and, therefore, would not be effective in the developing world. In 1994, the Rockefeller Foundation hosted an international meeting of experts to discuss how to support the development and delivery of an AIDS vaccine for the developing world. That meeting led to the creation of IAVI in January 1996, with support from several American private foundations, including the Rockefeller, Starr and Alfred P. Sloan foundations; Fondation Merieux of France; Until There's a Cure, an American nonprofit that raises funds for AIDS awareness; and the World Bank. The Rockefeller Foundation program director who headed the initiative became IAVI's CEO.

IAVI has become an influential player in the search for an HIV/AIDS vaccine. It began as an advocacy initiative designed to raise political awareness about the need for an HIV vaccine for developing countries and to make

\section{FIGURE 8 Amount of International Giving by Major Program Area, 2008}

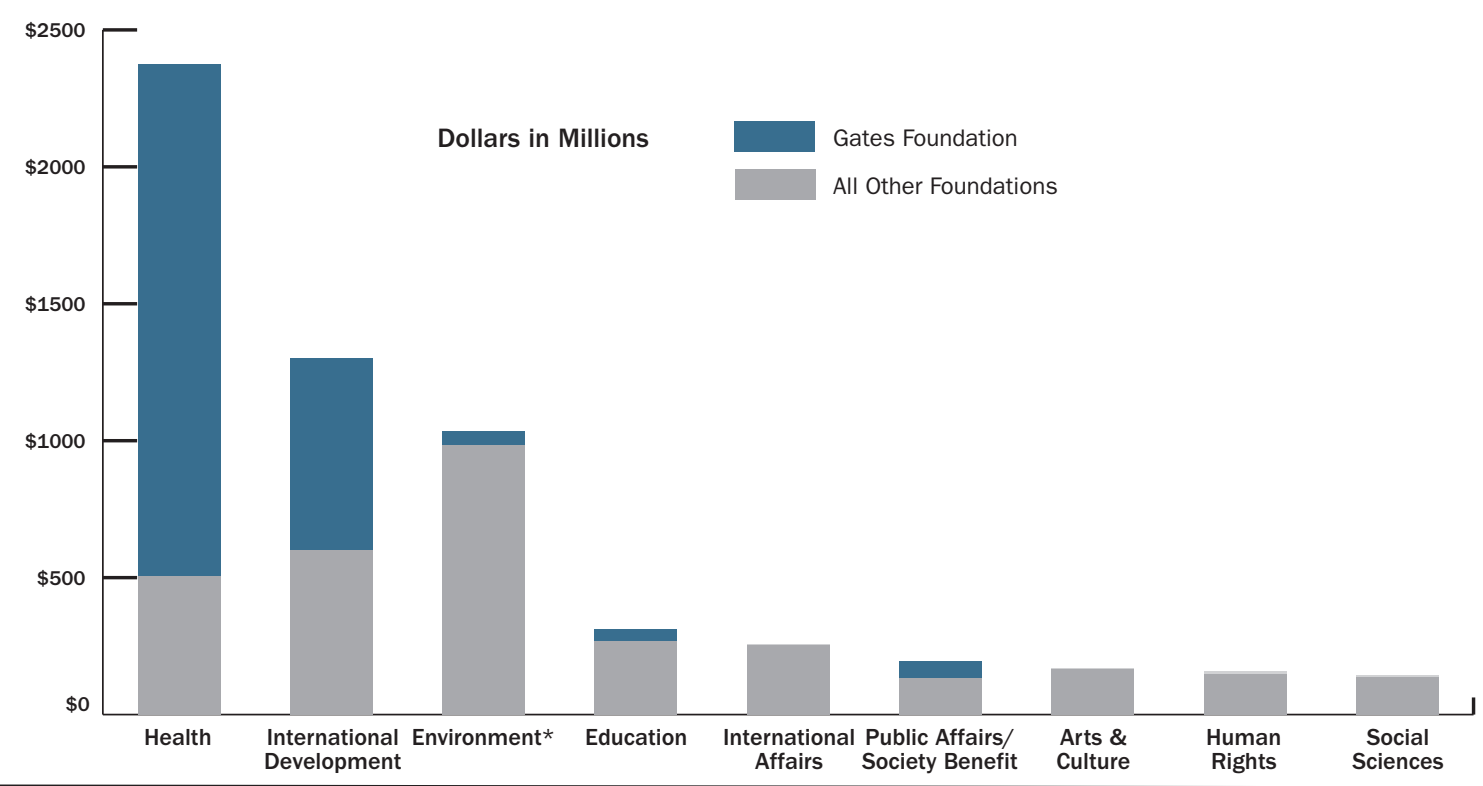

Source: The Foundation Center, The Global Role of U.S. Foundations, 2010. Based on all grants of $\$ 10,000$ or more from a sample of approximately 1,000 larger foundations *Includes a \$461 million multi-year Hewlett grant awarded to ClimateWorks Foundation. 
the development of such a vaccine a priority on the global public health agenda. Over time, it has evolved into an international organization that works with governments, academia, non-profit organizations, and private companies as a funder, operator and investor in vaccine programs. IAVI helps fund clinical trials of vaccines, trains staff conducting trials and research, coordinates and standardizes trials among different research sites, advocates with grassroots organizations and governments about the importance of clinical vaccine trials, and prepares for the eventual development of viable vaccines along with their marketing and distribution in developing countries.

IAVI also invests in companies that research and develop vaccines and, in return, obtains commitments to make the vaccine available to developing countries in reasonable quantities and at reasonable cost. Most recently, IAVI has begun investing in solving some of the major applied scientific challenges in developing a vaccine as well as developing some of its own vaccine products. IAVI's and its partners in government, universities, and pharmaceutical companies have moved seven new vaccine approaches into human trials and conducted more than twenty-five clinical trials in eleven countries.

Over the years, IAVI has raised close to $\$ 1$ billion. Today, almost 90 percent of IAVI's support comes from governments and international organizations. Private funders now include Gates, Hewlett, Starr and other private foundations along with a number of pharmaceutical companies, and other businesses. IAVI has become an influential global organization that has kept the world focused on the search for an effective HIV vaccine. Although IAVI and many other players have made important scientific progress towards their goal, the search for a vaccine remains elusive.
The International Partnership for Microbicides is another publicprivate partnership working on drug development. It was established in 2002 with significant funding from the Gates Foundation along with support from foundations, governments, and international organizations. IPM's objective is to accelerate the development and availability of safe and effective microbicides, drugs that protect women from HIV infection transmitted during intercourse and that a number of experts see as a tool for HIV/AIDS prevention in developing countries. The IPM works with pharmaceutical companies and governments to develop and conduct clinical trials, address regulatory issues, and prepare for the eventual manufacturing and distribution of the drugs. ${ }^{47}$

Foundations have also joined with governments, international organizations, and businesses in public private partnerships to bring HIV/AIDS treatments to developing countries. The largest is the Global Fund to Fight AIDS, Tuberculosis and Malaria, which is dedicated to the prevention and treatment of these three diseases of the developing world. Launched in 2002 as an independent public/private partnership, the Global Fund receives contributions from governments, private foundations, corporations and even private individuals. It has become the main source of financing for developing country programs addressing AIDS, $\mathrm{TB}$, and malaria and accounts for twenty-five percent of international funding for AIDS programs in developing countries. The Fund does not implement programs directly; rather it finances programs in countries that are committed at a national level to fight these diseases and that have developed coordinating mechanisms at the country level. The Global Fund is governed by a board of directors drawn from public and private sectors including a representative of a private foundation. ${ }^{48}$

\begin{tabular}{|c|c|c|}
\hline TABLE 3 & $\begin{array}{l}\text { Top U.S. HIV/AI } \\
\text { with a Primarily } \\
\text { Focus in } 2008 \\
\text { amount of inter } \\
\text { disbursements) }\end{array}$ & $\begin{array}{l}\text { S Funders } \\
\text { nternational } \\
\text { anked by } \\
\text { ational }\end{array}$ \\
\hline Foundation & & International (\$) \\
\hline Bill \& Melinda G & lates Foundation, WA & $\$ 378,482,751$ \\
\hline Open Society Ins & stitute, NY & $12,494,236$ \\
\hline $\begin{array}{l}\text { Elizabeth Glaser } \\
\text { Foundation, CA }\end{array}$ & Pediatric AIDS & $4,168,869$ \\
\hline Doris Duke Char & itable Foundation, NY & $3,830,000$ \\
\hline $\begin{array}{l}\text { HIV Collaborative } \\
\text { Tides Center, CA }\end{array}$ & Fund, a project of the & $3,001,210$ \\
\hline Rockefeller Brott & hers Fund, Inc., NY & $2,555,000$ \\
\hline The Starr Found & ation, NY & $2,005,000$ \\
\hline Global Fund for & Women, CA & $1,968,090$ \\
\hline Firelight Foundat & tion, CA & $1,872,084$ \\
\hline American Jewish & World Service, NY & $1,640,623$ \\
\hline $\begin{array}{l}\text { International Fun } \\
\text { Planning, NY }\end{array}$ & nd for Health \& Family & 950,109 \\
\hline $\begin{array}{l}\text { The William and } \\
\text { Foundation, CA }\end{array}$ & Flora Hewlett & 900,000 \\
\hline United Nations F & Foundation, DC & 753,346 \\
\hline $\begin{array}{l}\text { The Anne Dinnin } \\
\text { Foundation, NY }\end{array}$ & g and Michael Wolf & 750,000 \\
\hline South Africa Dev & relopment Fund, MA & 686,928 \\
\hline $\begin{array}{l}\text { The John D. \& C } \\
\text { Foundation, IL }\end{array}$ & atherine T. MacArthur & 615,000 \\
\hline The Summit Fou & ndation, DC & 568,000 \\
\hline $\begin{array}{l}\text { The David and } \mathrm{L} \\
\text { Foundation, CA }\end{array}$ & ucile Packard & 550,000 \\
\hline San Diego HIV F & unding Collaborative, CA & 541,000 \\
\hline BD (Becton, Dic) & kinson and Company), $\mathrm{NJ}$ & 524,027 \\
\hline The Skoll Found & ation, $\mathrm{CA}$ & 510,000 \\
\hline Staying Alive Fou & undation, $\mathrm{NY}$ & 468,765 \\
\hline Charles Stewart & Mott Foundation, MI & 370,000 \\
\hline World Children's & Fund, CA & 322,019 \\
\hline
\end{tabular}


Foundations have also used publicprivate partnerships to deliver HIV/ AIDS treatment. The African

Comprehensive HIV/AIDS Partnership was launched in 2000 as partnership of the government of Botswana, the Gates Foundation, and the pharmaceutical company Merck. ${ }^{49}$ ACHAP has a mandate to work on prevention, but its central goal is to deliver antiretroviral treatment, or ART in Botswana. In the 1990s, antiretroviral therapy revolutionized AIDS treatment in the developed world. Although it did not cure the disease, ART turned HIV/ AIDS into a chronic disease and saved countless lives. Furthermore, the lower viral loads resulting from ART helped moderate the transmission of the HIV virus. Many experts believed that ART could not be implemented in developing countries due to the cost of the medicines and the complexity of administering them, including the need for patients to follow a strict regimen in taking the drugs. In the late 1990s, Partners in Health, a Harvard-based organization under the leadership of Dr. Paul Farmer, demonstrated in Haiti that these experts were wrong: ART could be delivered effectively in a low resource setting. ${ }^{50}$

In 2000, Gates, Merck, and the government of Botswana set about testing that proposition in Botswana. Global health and HIV/AIDS are a major focus of Gates' philanthropy. Merck and other pharmaceutical companies holding patents on ART drugs faced strong public pressure from activists to reduce the cost of ART medicines in developing countries as well as threats from generic producers without patent protection that offered the drugs to poor countries at a much lower cost.

Merck and Gates each committed $\$ 50$ million for what was envisaged as a five- year program to develop an HIV/AIDS program that would become self-sustaining and integrated into efforts led by the Government of Botswana. Merck agreed to provide drugs at no cost. The partners targeted Botswana for several reasons: the country's manageable size-1.7 million people; the high prevalence of HIV/ AIDS $-17 \%$ of the population; ${ }^{51}$ what was seen as an adequate health system; the country's relative wealth from diamond production, which meant that the government could be expected to have resources to eventually assume responsibility for the program; and support from the country's political leadership. ACHAP is staffed by Africans. Its current managing director, for example, is a former Undersecretary of Botswana's Ministry of Health; its board is composed of representatives of Gates and Merck as well as HIV/AIDS experts and is chaired by an HIV/AIDS expert from the Gates Foundation.

ACHAP began by funding the development of a five-year national plan to provide free ART treatment to all citizens of Botswana. ${ }^{52}$ Despite strong support, the partnership had to address numerous problems. Although wealthy by African standards, Botswana had a shortage of health workers and inadequate medical facilities. While the government committed to the project at the highest level, responsibility for health and HIV/AIDS was divided among several ministries, complicating decision making and coordination. Furthermore, the relevant ministries were thinly staffed and inundated by requests from numerous other donors wanting to help.

The ACHAP partners did not have experience working together and naturally had different perspectives and expectations. They were also inexperienced in operating in the African political, economic, and social environment and thus were overly optimistic about the time needed to achieve their ambitious goals. Other donors working in HIV/AIDS in Botswana-the World Bank, various UN organizations such as UNICEF, the World Health Organization, and the Global Fund, the U.S. and other bilateral donor governments, as well 
as private donors- had their own perspectives, plans, standards, and requirements and proceeded on their own with little coordination.

When ACHAP'S original five year time frame proved too ambitious, Merck and Gates agreed to increase their financial support and to extend the project until 2009. Over time, ACHAP began to function effectively. The three partners-Gates, Merck, and the government of Botswana-developed their policies and procedures more fully and learned how to coordinate with each other. The international donor community also gradually learned how to cooperate and coordinate. ACHAP learned how to work with the government of Botswana, academic partners including the University of Botswana, Harvard University, and the University of Pennsylvania, and the local NGO community.

By 2008, ACHAP had achieved important goals. Through the University of Botswana and Harvard, it had trained 5,500 new healthcare workers on ART; its preceptor program had provided clinic based training to 3,200 physicians, nurses and other health care professionals; and 32 ACHAP ART clinics and 60 satellite facilities were up and running providing free treatment to over 100,000 people in Botswana. The program has also strengthened the local healthcare infrastructure including laboratory capacity, which has grown to be able to test over 20,000 patients per year. ${ }^{53}$ Finally, ACHAP now supports a national prevention plan including condom distribution, behavioral change interventions and communications.

\section{Funding Challenges in the Developing World}

ACHAP raises a number of issues central to HIV/AIDS funding as well as to other foundation projects in developing countries. First, publicprivate partnerships are not easy to manage. Foundations, business, and government bring different perspectives and interests to a partnership. Players need to understand and appreciate these different perspectives, interests, and needs. In particular, involvement of and ownership by local government and other local players is essential for long-term success but often is difficult to manage. Understanding these different interests, agreeing on objectives early on, and defining mechanisms for cooperation and coordination are critical to success. Establishing ways for partners to work with other donors and players in these countries is also essential. ${ }^{54}$

Second, the effective delivery of HIV/AIDS treatment must take into account the larger context including the health care system in which treatment is delivered as well as the importance of public education about prevention and sensitivity to the culture of those infected with the disease. Addressing developing countries' health systems, which are the delivery mechanisms for drug treatment, is a complex and thorny issue. In most places, those systems are weak and getting weaker as health care workers die of AIDS or take more lucrative jobs in developed countries. In fact, some critics have argued that greater funding for single diseases like HIV/AIDS has actually distorted the public health system by drawing away scarce resources-particularly health workers-from already vulnerable systems. While private and public support for research and care on AIDS, malaria, and tuberculosis has grown significantly, say the critics, there has not been adequate attention to the problems of public health and primary health systems in developing countries. ${ }^{55}$

Another aspect of the larger concern about health systems is the issue of prevention. While IAVI focuses on vaccine development and ACHAP focuses primarily on treatment, many critics have called for greater attention to prevention involving

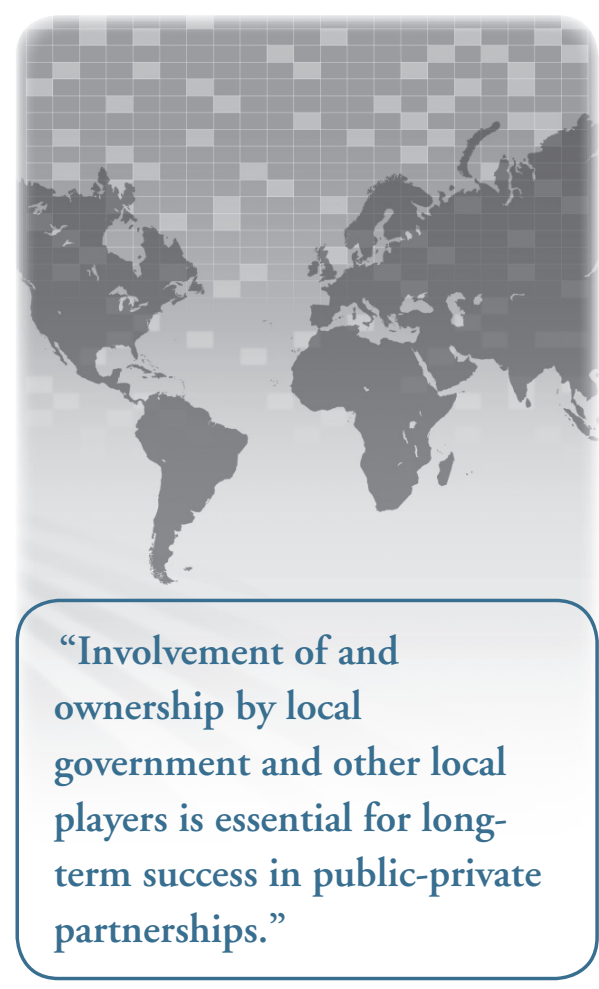




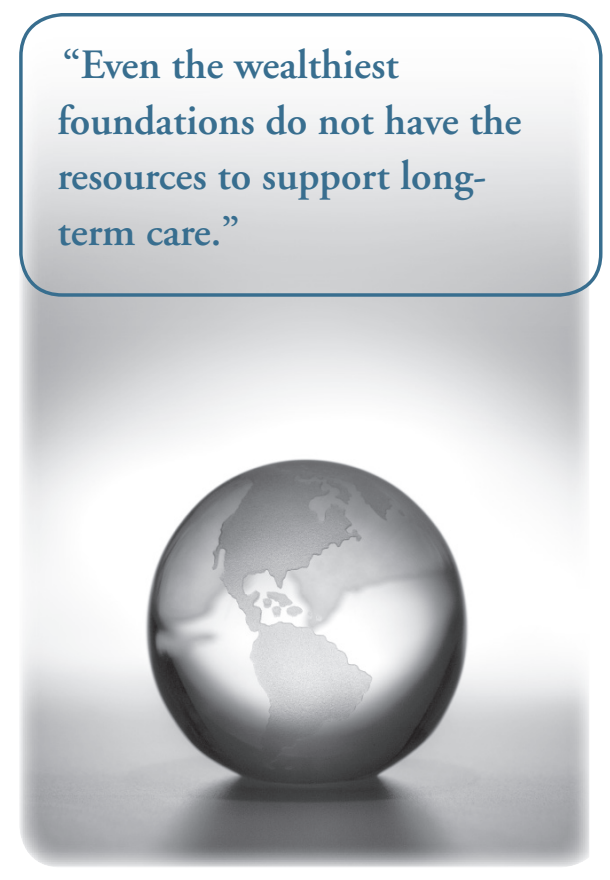

"Even the wealthiest

foundations do not have the resources to support longterm care." public education and public health approaches. In educating the public about prevention and persuading them to participate in treatment, it is also essential to address local cultural issues. Understanding how to reach people, change attitudes, and work with and through existing power structures and social relationships is essential to success. ${ }^{56}$

Some funders, including the Doris Duke Charitable Foundation and Rockefeller, have begun to address the issue of health systems. ${ }^{57}$ The Duke Foundation is supporting four pilot projects called Population Health Improvement and Training or PHIT Partnerships, whose goal is to learn how best to deliver primary, integrated health care in poor countries.

Rockefeller is financing health systems research, professional training for health systems managers, experiments that integrate the private sector into the healthcare system, and the use of interoperable eHealth systems.

Third, service delivery is an expensive and long-term proposition, particularly in the case of chronic diseases, which are different from vaccinations or other health interventions. Even the wealthiest foundations do not have the resources to support longterm care. They can, however, fund pilot programs and model efforts to test delivery methods that can then be adopted by governments and international organizations that have the resources to implement them and take them to scale. The issue is the ability and willingness of governments and other funders to assume that responsibility.

A fourth, related question is that of exit strategies: whether, when, and how will foundations exit HIV/AIDS programs they are funding? The goal of Gates and Merck has been to turn ACHAP over to the government of Botswana. Thus, these two partners worked closely with the government of Botswana to develop the infrastructure, equipment, and trained healthcare workers needed to implement the program over time. But what happens if the government or other funders are not able or willing to assume responsibility for ART delivery? Would Gates and Merck be willing to cut off or reduce life saving drugs for tens of thousands of people participating in the ART or other life-saving programs? This ethical question applies to many foundations working on AIDS and other health issues in poor countries.

\section{GLOBAL CHALLENGE: POVERTY}

Foundations were leaders in economic development long before governments and international organizations became involved. However, in the 1960s, as developing countries became a battleground in the Cold War, governments and multilateral organizations like the World Bank began to provide significant foreign assistance for development. The resources of governments and international organizations continue to far outdistance those of private foundations, which then turned to issues and projects they believed were not being addressed or not addressed adequately by official development assistance. Yet today funding for development is the second largest category of international grant making by major American foundations, accounting for 21 percent of international funding in 2008.

\section{The New Green Revolution}

While most foundations, as we shall see, support smaller experimental and pilot projects, the Gates and Rockefeller foundations have joined in a philanthropic program at a much larger scale: trying to create a new Green Revolution in Africa. Despite its many successes in Latin America and Asia, the Green Revolution did not transform agriculture in subSaharan Africa where conditions were very different. Food production in sub- 
Saharan Africa has actually declined in the last thirty years; and countries that once were food sufficient or food exporters now rely on imports and food aid. The majority of Africans depend on subsistence farming whose productivity is limited by many factors: harsh environments with frequent droughts, poor soil quality, diverse soils and environments requiring varied products and seed types, a lack of infrastructure like roads and irrigation, plus poorly developed agricultural markets. Food production in Africa has also suffered from development policies of African governments which historically emphasized industrial not rural development. Finally, while official international aid to subSaharan Africa has increased in the last three decades, aid to agriculture has declined significantly. ${ }^{58}$

The Gates and Rockefeller foundations are now experimenting with ways to address this complex set of problems through a new program modeled on the original Green Revolution but adapted for sub-Saharan Africa. In 2006, Gates committed $\$ 100$ million and Rockefeller $\$ 50$ million to create AGRA, the Alliance for a Green Revolution in Africa. Its goal is to increase food production and sustainability of agriculture in Africa and to improve the plight of small farmers. The funders created a new organization based in Nairobi, Kenya, with a governing board chaired by former United Nations Secretary General Kofi Annan. Since 2006, AGRA has worked with African governments and the UN organizations FAO, IFAD, and WFP. Gates subsequently more than doubled its financial commitment to the program.

The central elements of the comprehensive strategy are to: improve the availability and variety of seeds that can produce higher and more stable crop yields; improve soil fertility through better management and access to fertilizers; increase access to and develop efficient means of using water; train experts in agricultural research and production; and improve markets, transportation, and finance for agricultural inputs and food products. AGRA staff stress their emphasis on sustainability of agricultural methods. ${ }^{59}$ Thus far, AGRA has funded training for crop breeders and agricultural scientists; supported crop breeding and the distribution of new crop varieties; and helped established agro-dealers who are central to seed distribution. It has also funded improved information about African soils and the use of fertilizers.

It is far too early to judge the impact of AGRA. Supporters praise the integrated approach to agricultural production, AGRA's cooperation with governments and the UN, its emphasis on sustainability, and the attention it has brought to the problems of subsistence agriculture in Africa. Critics raise the same concerns as they do about the original Green Revolution: whether the program will rely on costly technological solutions that may endanger the environment including inorganic fertilizers, pesticides, and herbicides as well as hybrid seeds and irrigation. Some critics have expressed concerns about the role of large American foundations and the privatization of foreign aid. ${ }^{60}$ Finally, AGRA raises the eventual question of long-term sustainability: whether pilot programs will be successful and then be adopted and taken to scale by local governments and/or foreign funders.

\section{Pilot Programs}

Even large American foundations do not have the resources of the Gates Foundation. Those who seek to play a role in alleviating poverty and promoting development have financed a variety of exploratory and experimental studies, solutions, policies, and technologies to address development and poverty, especially rural development and poverty. The intention is that research will inform public policy and that pilot

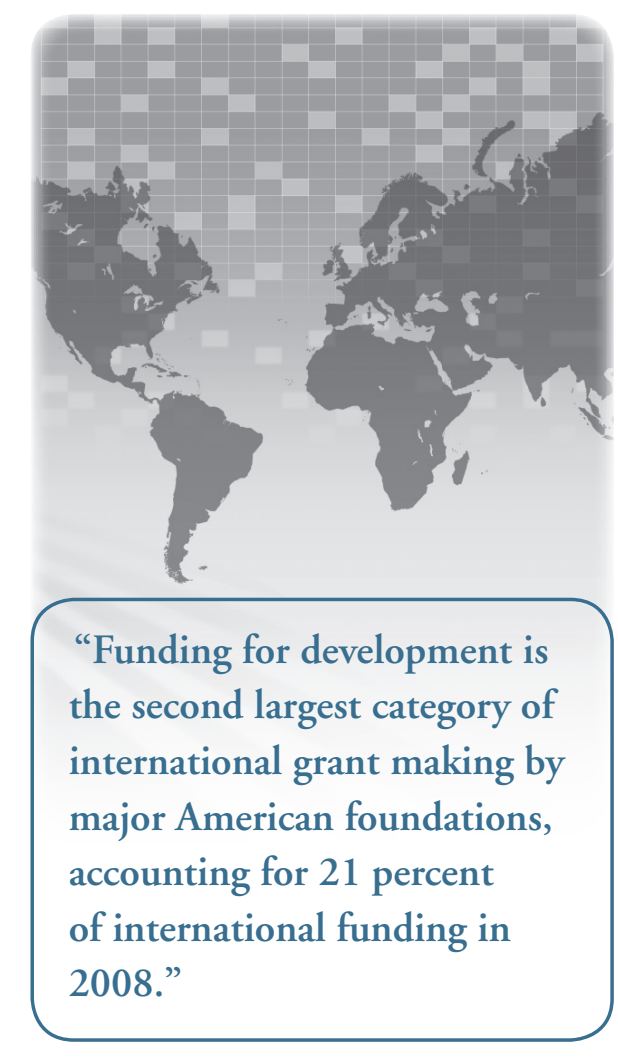




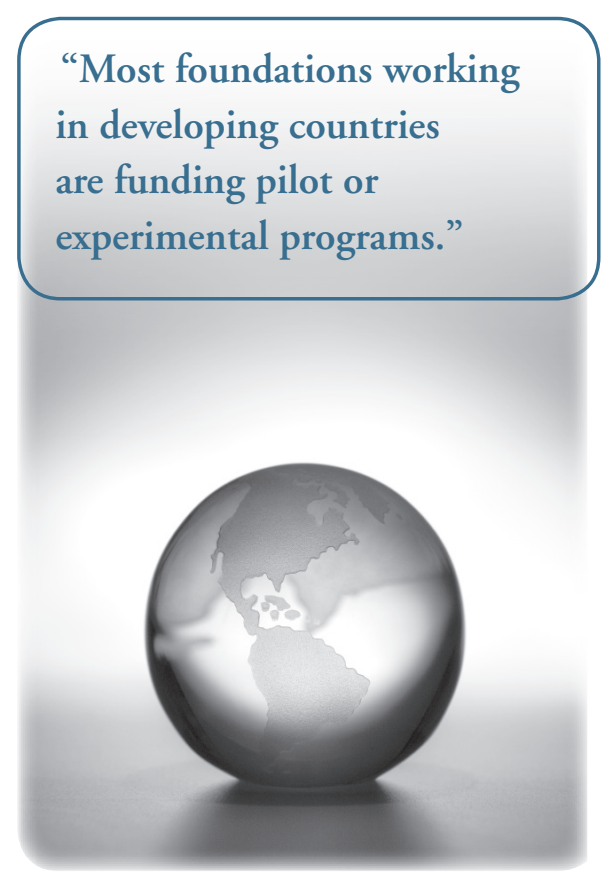

programs, if successful, will be adopted and sustained by governments, international organizations, or other sources of funding. Thus, for example, Hewlett funds studies about improving agricultural markets in Africa through trade policies, information technologies, markets for seeds and fertilizers, and infrastructure. ${ }^{61}$ Harkening back to the Green Revolution, Rockefeller has funded the development of a new strain of rice with vitamin A that prevents blindness and reduces the incidence of childhood diseases. ${ }^{62}$ It is also funding the study of urbanization in poor countries. ${ }^{63}$ Foundations have also taken on politically sensitive issues. Hewlett, MacArthur, and Packard, for example, support reproductive health and family planning programs. ${ }^{64}$

\section{Social Entrepreneurship}

Social entrepreneurship has become a popular philanthropic strategy in both developed and developing countries. ${ }^{65}$ Social entrepreneurs are defined as people who identify social needs and problems, address them in innovative ways, and pursue longterm social change. While many social enterprises are non-profits, they may meld profit and non-profit activities. Most often, their work begins at small scale and at the local level. One early and frequently cited international example is the creation of microfinance by Nobel Laureate Muhammad Yunus of Bangladesh. In 1976, the Ford Foundation gave Yunus his first grant to experiment with his idea of offering very small loans to poor villagers, primarily women, in Bangladesh. Microfinance has since become a worldwide movement involving governments, international organizations, businesses, and foundations. ${ }^{66}$

Some new philanthropists who have started their own technology companies have been particularly attracted to market-oriented approaches to social problems including poverty. ${ }^{67}$ For example, in 1999, Jeff Skoll, the first president of eBay, created the Skoll Foundation, which is devoted to social entrepreneurship. It makes awards to successful social entrepreneurs to enable them to expand their work, helps social entrepreneurs connect with other people and resources to advance their programs, and supports academic research on social entrepreneurship. Some Skoll awards have gone to programs addressing poverty, including one that helps Afghan women earn income by selling their rugs and another that trains Indian rural villagers in engineering and teaching. ${ }^{68}$ There are major questions about social entrepreneurship, including whether programs that are successful at a local level can be taken to scale, affect poverty more widely, and be sustainable over time. ${ }^{69}$

\section{Impact and Sustainability}

In the days of the first Green Revolution, foundations were major supporters of economic development in poor countries and contributed in important ways to economic, social, and political change. Today, the aid programs of governments and multilateral organizations dwarf those of foundations. Thus, foundations have explored where and how they can play a role and have an impact in the developing world. Some, like the Gates Foundation, have the resources to create ambitious programs like AGRA or ACHAP. Others seek to leverage their more limited but still significant resources by partnering with business, governments, and multilateral organizations. Many look for niches where they can affect social change. Some focus on education, where they believe they can have an impact over a sustained period of years. Others, as we shall see, focus on promoting civil society and empowering those without a voice in their societies and polities. Some have taken on politically sensitive issues such as population, continuing to fund these issues 
even when the United States would not. Others experiment with social entrepreneurship. Most foundations working in developing countries are funding pilot or experimental programs. The question is whether these pilots will be successful and, even if they are successful, whether they will be taken to scale and adopted by governments, multilateral organizations, or other funders.

\section{GLOBAL CHALLENGE: CLIMATE CHANGE}

Environment is the third largest category of international funding, representing about 17 percent of international giving in 2008. A significant portion of that funding is directed to environmental conservation and preservation. However, in the last two decades American foundations have given increasing attention to global climate change. They have supported research, policy development, and advocacy for policies at home and around the world to stop global warming and have funded the research, design, and advocacy for new international regimes to address climate change. In doing so, foundations have funded existing organizations and also created new ones in the United States and abroad to carry out climate change work.

Foundations' concern about global warming grew out of a long-standing commitment to environmental protection. During the 1980 s and 1990s, many foundations supported environmental programs. They supported natural resource conservation in the United States and abroad and financed work on environmental and health problems associated with industrial and energy pollution of land, water, and air. Foundations financed programs to expand science and education, change public policy and public finance, as well as acquire and preserve biologically significant habitats. For example, Packard focused on protecting marine and ocean habitats; Pew funded forest protection; Doris Duke supported land acquisition to protect wildlife; and MacArthur created the World Resources Institute, a research institution devoted to environmental science and policy. Some foundations, including Packard and MacArthur, supported international programs to protect biological diversity outside the United States. ${ }^{70}$

In the early 1990s, a number of foundation leaders became aware of the growing scientific evidence of global warming and began to fund policy studies and advocacy on global warming at the local, state, and national level in the U.S., thus joining the growing number of civil society organizations working on the problem of global warming. Foundations supported major U.S. environmental organizations such as the Natural Resources Defense Council, Environmental Defense Fund, and the World Resources Institute to conduct climate change research, policy development, and advocacy. Foundation funding also went to these and other environmental organizations, research institutions, and universities to design and develop international climate regimes including emission trading schemes and renewable energy policies, and to fund policy research and development on implementing technologies such as carbon capture and storage. Foundations such as Rockefeller Brothers and the United Nations Foundation (a public charity that receives funding from numerous sources including its founder, billionaire Ted Turner) also supported environmental organizations and nontraditional players like farmers and faith- based organizations to advocate for climate change policies at the local, state, and national level in the U.S.

Foundations also established new organizations to work on climate change. The Pew Center on Global Climate Change, for example, was created in 1998 by 
the Pew Charitable Trusts. Based in Washington, the Center conducts research and analysis, develops policy proposals for the federal government, and advocates for action with officials and various public stakeholder groups. It also addresses U.S. international climate policy by, for example, developing model international agreements on climate change, analyzing technical provisions for trading and measuring carbon emissions, and devising policies for dealing with China and India on climate change. ${ }^{71}$

\section{The Energy Foundation}

The Energy Foundation was created in 1991 by the MacArthur, Pew, and Rockefeller foundations. ${ }^{72}$ Their presidents were concerned about the environmental impact of U.S. dependence on fossil fuel, which at the time was seen primarily as air pollution, and decided to jointly engaged an energy expert to do research and advise them on how they might work together to improve the environment by advancing energy policy. The resulting study described the costs of pollution from carbon dioxide emissions and made the case for shifting the world away from a reliance on fossil fuel. It argued that new technologies can produce economic growth with far less pollution, public policies can shape the development of new technologies and energy markets, and intelligent philanthropy can shape energy policy and contribute to dramatic reduction in energy use and related carbon emissions.

MacArthur, Pew, and Rockefeller then committed a total of $\$ 100$ million over 10 years to create the Energy Foundation. The new organization, which is staffed by energy experts, makes grants to non-profit organizations to fulfill its objectives. In effect, the Energy Foundation enabled the three founders to outsource their energy grant making through a special purpose foundation. Over time, funding shifted as Rockefeller and MacArthur withdrew while the Hewlett, Packard, McKnight, Mertz Gilmore, and Doris Duke Charitable foundations and wealthy individual donors joined as supporters.

The Energy Foundation has helped design U.S. local, state, and national standards for renewable energy, efficient appliances, and utility efficiency; developed regulations for vehicle emissions and energy efficient building codes; and worked with a variety of advocacy organizations and helped build coalitions to press for the implementation of these standards and codes. When the George W. Bush Administration opposed national climate change legislation and international climate change negotiations, the Energy Foundation and other environmental groups focused their efforts at the state and regional level including, for example, the passage of auto emission standards in California.

The Energy Foundation has also created a program in China. In 1998, the Packard Foundation funded the Energy Foundation to study opportunities to change energy policy abroad. Research pointed to China, whose size and rapid economic growth made it a significant consumer of energy and carbon emitter, and therefore an essential ingredient in any solution to global warming. The study concluded that China's domestic energy policy would shape that country's ability and willingness to participate in international agreements to reduce carbon emissions. It also found that China's leaders were receptive to change, but that the country had little internal capacity to develop such a policy.

So, in 1999, the Energy Foundation launched the China Sustainable Energy Program with a $\$ 25$ million, fiveyear grant from Packard. The CSEP subsequently received support from Hewlett, Doris Duke, and others. 
By 2010, the program had an office in Beijing staffed by 32 Chinese nationals and an annual budget of $\$ 35$ million. ${ }^{73}$ CSEP's strategy is to bring best international practices to China. It supports the design, development, and implementation of new sustainable energy standards and policies by making grants to Chinese research institutes and international NGOS, commissioning research, and convening experts from around the world to inform Chinese researchers, analysts, and government officials. A number of the standards developed by CSEP grantees have been adopted by the central Chinese government and the foundation is now also working to assure that those decisions are put into practice in China. ${ }^{74}$

\section{U.S. foundations are taking the} Energy Foundation model to other countries and regions. In 2007, the Hewlett, Packard, Oak, Doris Duke, Joyce, and Energy foundations jointly commissioned a study entitled "Design to Win" to make recommendations about international strategies that philanthropy might use to address global warming. The study recommended a global initiative, modeled on the Energy Foundation's work in the United States and China, to create an organization to support the design of and to advocate for sustainable energy policies in key countries and regions around the world. ${ }^{75}$

\section{ClimateWorks Foundation}

In 2008, a new foundation was launched to implement the strategies articulated in the "Design to Win" study. The goal of the ClimateWorks Foundation, created with backing from the Hewlett, Packard, and McKnight foundations, is to reduce global greenhouse gas emissions by focusing on the regions and sectors with the greatest promise of emissions reduction. ClimateWorks raises funds on a global basis and operates through a network of international climate change organizations that share best practices and that collaborate and coordinate on national and international climate strategies and policies.

Some members of the network are country or regional organizations. The Energy Foundation is a member and has received significant funding for its China Sustainable Energy Program from ClimateWorks. Another important participant is the European Climate Foundation. ECF was created in 2008 by European foundations (e.g. the Oak and Children's Investment Fund foundations) with both financial and technical support from U.S. foundations (e.g. the Hewlett and Energy foundations). Led and staffed by Europeans, the mission of the ECF is to promote policies that reduce Europe's greenhouse gas emissions and to strengthen European international leadership on mitigating climate change. It supports programs on energy efficiency, power, transportation, climate policies, and diplomacy.

The newest member of the ClimateWorks network is Shakti, an Indian climate foundation created with funding from Indian donors as well as the Oak, Hewlett, Packard, and McKnight foundations. ClimateWorks provided start up funding for Shakti, and it recruited and trained its CEO. The global network also includes international professional groups with technical expertise in fields where carbon emissions can be reduced or avoided, such deforestation, transportation, urban planning, building and appliance standards, and power. Examples of these sector networks are the International Council on Clean Transportation whose members are fuel regulators and the Regulatory Assistance Project composed of utility regulators. These sector groups develop best practices in their fields of expertise and promote them on a global basis.

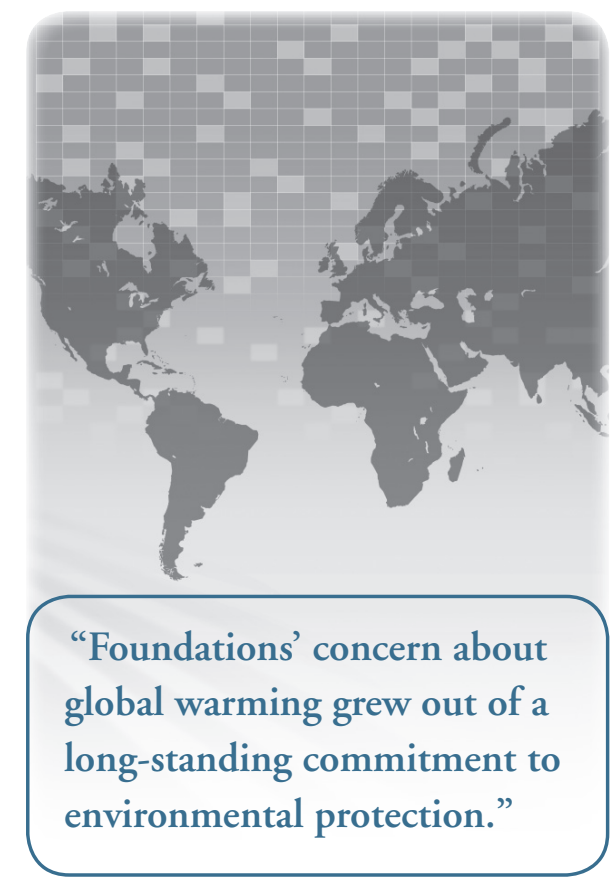


"In one way or

another, the work of

foundations on climate

change involves advocacy

for new laws, policies,

and international regimes."
ClimateWorks has also created an initiative called Project Catalyst to support and advance international climate change negotiations. This project provides technical support to climate change advocates in several countries and through them to their government officials engaged in international climate change negotiations. Project Catalyst provides countries with decision support, i.e. analysis and measurement of policy options for reducing national carbon emissions and evaluation of their impact on national economies. ClimateWorks has also formed a partnership with McKinsey, the international consulting firm, to help provide this decision support and analysis. Project Catalyst also examines broader standards and requirements that will be needed for an international regime. ${ }^{76}$

\section{Advocacy}

In one way or another, the work of foundations on climate change involves advocacy for new laws, policies, and international regimes. In some cases, as with the Energy Foundation's China Sustainable Energy Program, foundations have helped to change laws and regulations, if not yet the practice of energy policy. In other cases, as with ClimateWorks, it is too early to know whether that model can be expanded on a worldwide scale. An important question is how these advocacy programs are perceived abroad: whether foundation support for cross border advocacy is seen as legitimate or intrusive in other countries and by whom.

\section{GLOBAL CHALLENGE: DEMOCRACY AND CIVIL SOCIETY}

Promoting liberal democracies abroad was a central theme of foundations during the Cold War. Foundations helped rebuild democratic systems in Japan and Germany after World
War II and then turned to developing countries where they trained new elites, sponsored higher education, provided technical assistance to new governments, and promoted economic development as the route to democracy. After the collapse of communism, U.S. foundations played a similar role in Eastern Europe and the former Soviet Union and, today, they support a variety of democracy programs in former communist countries and throughout the developing world.

Contemporary foundation strategies for promoting democracy vary widely in geography and type and are difficult to classify in simple categories. In general, there are four main themes of democracy funding: support for higher education and training, the rule of law, independent media and public information systems, and strong non-profit or civil society sectors. ${ }^{77}$ Education receives the largest amount of funding.

Foundations provide significant funding for higher education including fellowships and scholarships for individuals in developing countries particularly those from disadvantaged groups. For example, the Andrew W. Mellon Foundation provides hundreds of fellowships for higher education to disadvantaged individuals in South Africa; Carnegie offers hundreds of doctoral and post-doctoral fellowships in the humanities in Ghana, Nigeria, South Africa, Tanzania, and Uganda; and Ford has endowed the International Fellowships Program which awards thousands of fellowships for post-graduate study in universities worldwide to leaders from underserved communities throughout the world. ${ }^{78}$

Other education funding has gone to universities or academic centers abroad to support libraries, research institutes, publications, academic meetings, and institutional reform. Under the Partnership for Higher Education in Africa, Carnegie Corporation, MacArthur, Rockefeller Foundations, Ford, Hewlett, Mellon and Kresge 
committed nearly $\$ 350$ million to forty-nine universities in nine African countries in the years 2000 to $2009 .^{79}$ Funding has supported physical and technological infrastructure as well as post-graduate education and research. For example, the Mellon Foundation has funded graduate education and faculty development in South Africa, and made significant contributions to the modernization of South African libraries and the availability of digital resources for universities. ${ }^{80}$ Foundations are also active in former communist countries. For example, the Carnegie Corporation has supported university-based centers in Russia and Eurasia to promote academic research, publications, and networks of scholars.

Foundations also fund programs that foster the rule of law, especially international human rights law. Foundations support training judges, developing courts, educating judges and law enforcement officials about different legal systems, monitoring legal practices, and fostering respect for human rights. The MacArthur Foundation, for example, sponsors programs to develop international systems of justice such as the International Criminal Court; train judges in the application of human rights law; and reform courts and law enforcement agencies to improve human rights protection. Ford supports numerous national, regional and international human rights organizations that work to enforce international human rights law and standards. ${ }^{81}$

Foundations also support independent media and public information systems. For example, OSI funds the Media Development Loan Fund, which provides low-cost capital and technical assistance to help journalists build professional and responsible media businesses. OSI has also funded media programs to strengthen independent print, broadcast and online media in Africa and Russia. The Mott Foundation funds public interest programs in the Balkans and Russia, media training in central Europe, and monitoring of the coverage of race by the media in South Africa.

Other foundation programs seek to make governments accountable and transparent and to make information about government policies and practices available to the public. For example, OSI established the Africa Governance Monitoring and Advocacy Project to monitor the compliance of members of the African Union with standards of good governance, democracy, human rights, and the rule of law. The International Budget Partnership helps civil society organizations in Africa, Asia, Latin America, Eastern Europe, Russia, and the Middle East to understand, analyze, and influence government budgets and subject them to public scrutiny and debate. The IBP was started by Ford in 1997 and is now funded by the Ford, Gates, and Hewlett Foundations, and OSI, as well as the UK and Swedish governments. ${ }^{82}$

Foundations also support civil society organizations around the world. U.S. foundations especially Carnegie, Ford, Kellogg, Mott, Rockefeller Brothers, and OSI have devoted significant funding to civil society organizations in South Africa both before and after the end of apartheid. They have supported South African groups engaged in advocacy, public interest law, training of NGOs, social and community organizing, civic participation and empowerment. ${ }^{83}$ Foundations are actively supporting civil society groups elsewhere around the world. OSI, for example, funds the Trust for Civil Society in Central and Eastern Europe to promote the development of civil societies in Bulgaria, the Czech Republic, Hungary, Poland, Romania, Slovakia and Slovenia. The Rockefeller Brothers Fund, a founder of the Trust for Civil Society, supports civil society groups working on sustainable development in southern China and the Western Balkans. Mott has 
supported civil society groups in Eastern Europe, the former Soviet Union, and the Balkans.

Democracy programs to educate leaders, enhance the rule of law, strengthen free media, and build civil society are long-term, experimental, risky, and difficult to evaluate or measure, especially in the short and medium term. Efforts to reach and change civic behavior are, by definition, diffuse, diverse, and dispersed. Foundations may invigorate local groups or create dependencies or simply be irrelevant. Foundations may be politically cautious in funding only professional organizations as opposed to grass roots organizations or social movements. Furthermore, civil society organizations and educated leaders operate in a larger political, economic and social environment which shapes their ability to influence democracy and liberal economies. Foundations cannot export democracy; foundation efforts must align with local culture and local history. Thus, the impact of foundations in building democracy can only be known over time, if at all. ${ }^{84}$

\section{Eastern Europe and Russia}

The strategies of foundations in Eastern Europe and Russia in the 1990s offer insights into the democracy work of foundations and enable one to evaluate their impact. The

\section{FIGURE 9 Foundation Giving to Overseas Recipients in Eastern Europe, Russia, and the Independent States, 1990 to 2008}

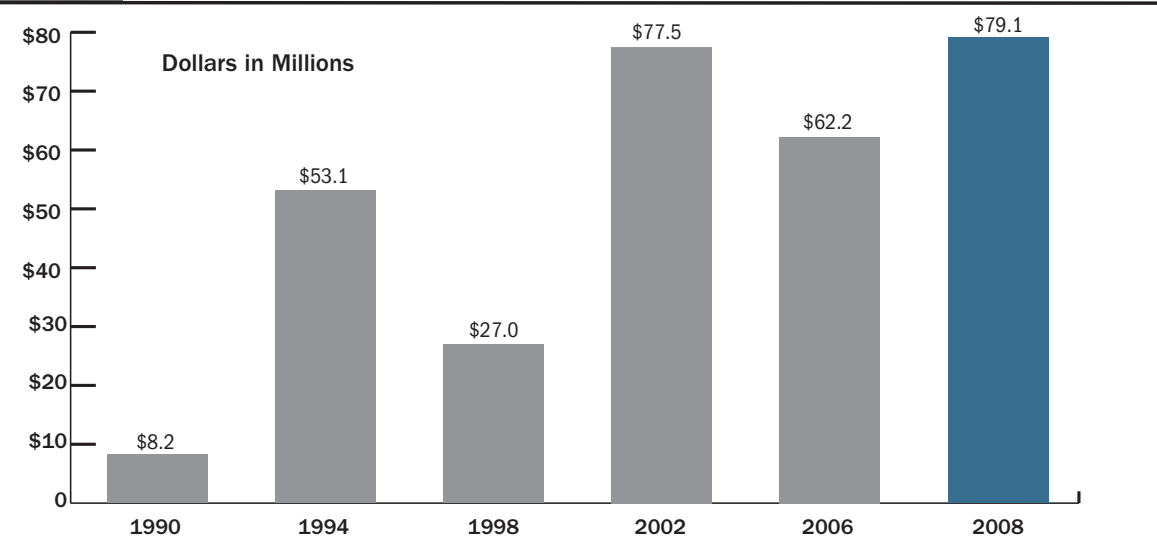

Source: The Foundation Center, The Global Role of U.S. Foundations, 2010. Based on all grants of $\$ 10,000$ or more from a sample of approximately 1,000 larger foundations. transition of formerly communist countries to democratic government and free market economies has been one of the major global challenges of the late twentieth and early twentyfirst century. Foundations, along with governments, international organizations, and non-profit organizations played and continue to play an important role in that transition. Foundations first became involved in Eastern Europe in the 1970s and 1980s by supporting intellectuals, dissidents, and nascent civil society groups behind the Iron Curtain. After the collapse of communism in 1989, foundations moved rapidly and with significant funding to support the transition from communism to democracy and free markets. Because they did not need legislative or other governmental approval or funding, foundations were able to move into Eastern Europe before Western governments were able to mobilize assistance. Traditional international funders as well as foundations that had never engaged in international funding channeled funds to Eastern Europe after 1989. ${ }^{85}$ U.S. foundation support for the former communist countries jumped from $\$ 8.2$ million in 1990 to $\$ 53.1$ million in 1994 (See Figure 9).

Western government assistance for Eastern and Central Europe was far greater than philanthropic assistance. Although some official funds were directed at the types of activities and organizations supported by foundations, ${ }^{86}$ the bulk of government funds was targeted at supporting political and economic reforms and directed primarily through other governments. For example, the principal U.S. government assistance program, Support for Eastern European Democracy or SEED, focused on the institutions as well as the legislative and regulatory framework of democracy and private markets. It provided assistance to develop democratic institutions including free elections, 
an independent judiciary, and nonpartisan military, security, and police forces. SEED also promoted free market economic systems by supporting privatization, establishment of property rights, simplification of regulations, and removal of trade restrictions. $^{87}$

Foundations focused on building liberal democracy and market economies at the grass roots. The largest amount of funding went to higher education and research in the former communist countries. Higher education in the region was in difficult straits in 1989. Communist governments had exerted control over universities and research institutions and favored natural sciences and technology over humanities and social sciences. Research in general was limited and weak, facilities were poor, and Eastern scholars had few contacts with scholars and scholarship outside the communist bloc. ${ }^{88}$ The intention of Western donors including foundations and public donors such as the World Bank was to reform and modernize higher education in central and Eastern Europe as the basis for democracy and vibrant market economies and thereby to develop human talent especially in market economics, Western science and scientific systems, social sciences, and management. ${ }^{89}$

One important example was the Central European University, created by the Soros Foundation. CEU was established in Prague in 1990 and eventually moved to both Warsaw and Budapest, where its major activities are located. Beginning with a contribution of \$25 million, Soros eventually donated $\$ 800$ million to create and endow the University. CEU began by providing Western-style education in English for students from Eastern Europe and then expanded to include students from Western Europe, other former communist countries, and the developing world. In 1996, it was accredited by the State of New York Board of Regents as a doctorate granting institution..$^{90}$
Soros created and funded other education initiatives. The Higher Education Support Program (HESP) promoted educational reform and linked Eastern European scholars and educational institutions with the international academic community. The Civic Education Project (CEP) supported Western scholars to teach in Eastern Europe and to assist educational reform there. ${ }^{91}$ Immediately after the break-up of the Soviet Union, Soros provided emergency grants to scientists in the former Soviet Union, and then went on to create and fund the International Science Foundation in Russia whose goal was to integrate scientists from the former Soviet Union into the international scientific community by providing grants for research, conference travel, internet access, and subscriptions to scientific periodicals. ${ }^{92}$

Other foundations focused on research and integrating Eastern European scholars into the Western research system. The Andrew W. Mellon Foundation, the Pew Charitable Trusts, USAID, the Sara Scaife Foundation, and others funded the creation and provided long-term operating support to the Center for Economic Research and Graduate Education, or CERGE, which was initially affiliated with Charles University and the Czech Academy of Sciences in Czechoslovakia. ${ }^{93}$ Similar programs were created by Mellon and other donors in other Eastern European countries. ${ }^{94}$ Each posed varying levels of complexity and difficulty, but most survived and fulfilled their goals of improving research and education in modern economics.

Mellon also gave special attention to academic and research libraries. It funded subscriptions to scholarly journals and books, library automation, exchanges of experts to transfer the latest library technology and methods from West to East, and the creation of library consortia in the Czech and Slovak republics, Hungary, and Poland, including providing the hardware and

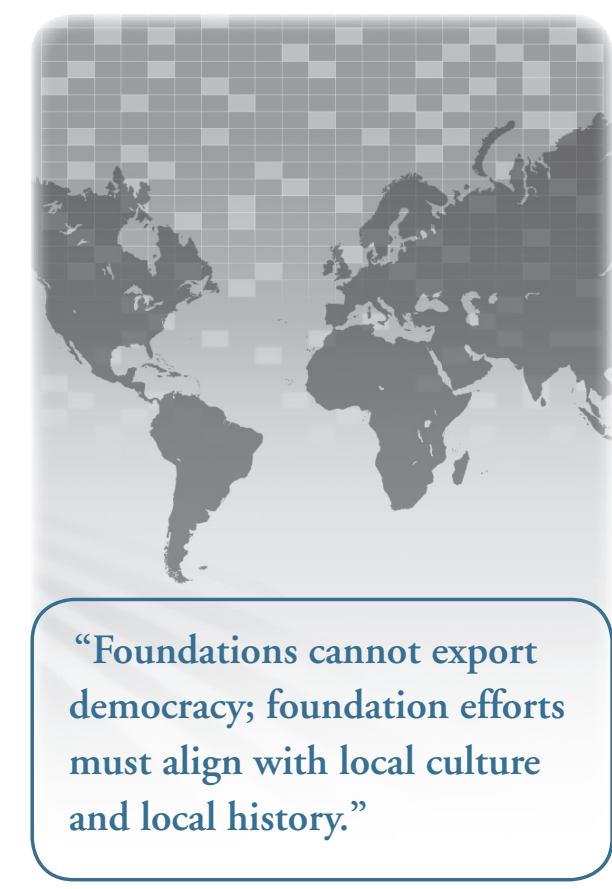




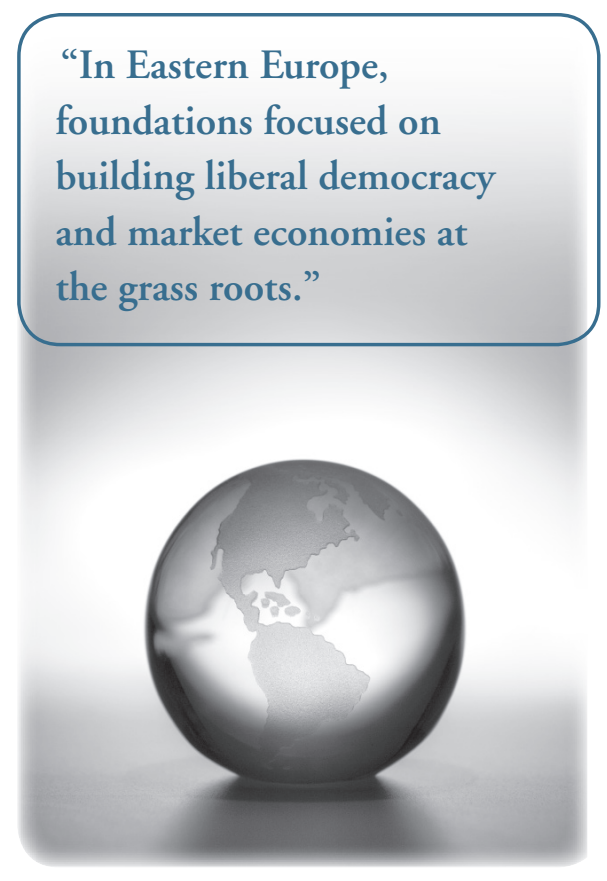

software that enabled libraries to link with each other and with research institutions around the world. The director of the program has described in detail the successes, frustrations, and failures of the Mellon programs, and concluded that the impact, especially the impact of library consortia, was significant. ${ }^{95}$

The MacArthur Foundation has funded a variety of programs for higher education in Russia with a special emphasis on science and social science. Its goals have been to build independent scholarship and strengthen universities, independent think tanks, and journals. MacArthur has supported centers of excellence at state universities, independent public policy institutes, and scholarly journals and academic networks.

The second major strategy of foundations in Eastern Europe was support for civil society organizations. Support for non-profit groups reflected the strong belief of foundation leaders in civil society as a balance to government and business and therefore an essential element of liberal, pluralist democracies. Support for non-profit organizations also reflected a practical assessment about the comparative advantage of foundations. In the United States and other countries where they operate, philanthropic organizations are part of the civil sector and, therefore, are considered legitimate supporters of independent civil society organizations. Foundations also have long experience with and expertise in supporting nongovernmental organizations at home and around the world. Furthermore, foundations mainly make grants, not loans, and are better equipped than governments to make smaller grants of the type appropriate for civil society organizations.

During communist rule, the state sought to control all social, economic, and political activity. As a result, when the communist regimes collapsed, there was no legal infrastructure and little knowledge about creating, operating, and funding non-governmental organizations. From 1989 until the mid-1990s, foundations provided significant support to build the capacity of civil society in Eastern Europe through training, leadership development, and technical assistance for nonprofits.

In some cases, foundations provided direct support for non-governmental organizations, usually through some form of intermediary. George Soros established foundations in the countries where he made grants including Hungary, Poland, the Czech and Slovak Republics, and used these foundations to give money directly to civil society groups. A consortium of U.S. foundations worked through the German Marshall Fund to create the Environmental Partnership for Central Europe. Its offices in Hungary, Poland, and the Czech and Slovak republics provided grants, fellowships, workshops and seminars, publications, information and networking in environment and sustainable development. The EPCE was initially funded by U.S. donors and managed by U.S. executive officers but later developed its local sources of funding through individual donors, earned income, and even endowments. ${ }^{96}$ MacArthur supported a number of grants to civil society organizations in Russia, especially those focused on rule of law and human rights.

Foundations also created service or intermediary organizations to develop NGO capacity. Mott and the Rockefeller Brothers Fund, for example, helped establish a network of centers to provide information about legal, financial and management issues affecting non-profits as well as to train leaders and facilitate cooperation among non-profit organizations in Eastern Europe. Mott funded the Forum of Polish Foundations, a membership organization that represented the non-profit sector to government and the private sector, 
served as a source of information, advocated legal and fiscal policies that support non-profits, and provided legal, financial and technical services to the non-profit sector. Mott and Rockefeller Brothers also supported the Civil Society Development Program to train non-profit leaders in Hungary and Poland. ${ }^{97}$

Foundations began to scale back their activities in the major countries of Eastern Europe in the late 1990s. Some concluded that their work was done and could be turned over to local citizens and Western governments. Others tried to address the issue of long-term sustainability by helping grantees diversify their funding and create endowments. Some seeded local foundations in an effort to develop indigenous philanthropy in Eastern Europe. By the late 1990s, most foundations were no longer active in the major countries of Eastern Europe and had either exited the area or, like Soros, Ford, and Rockefeller Brothers, moved their funding to other former communist countries in the Balkans and Caucasus.

\section{Impact and Sustainability}

Studies of the work of foundations in Eastern Europe have identified important achievements as well as shortcomings. Most conclude that foundation support accelerated the development of academic and research institutions, modern libraries, and civil society organizations that now operate and thrive in Eastern Europe. Many of the organizations that foundations helped to establish such as the Central European University and the Trust for Civil Society continue to play an important role in education and civil society development. Foundations also played an important role in facilitating interaction of scholars from the former communist countries with Western scholars and modern academic thought. And in so doing, foundations and other donors eased and accelerated the transition from communism to liberal democracy and market economies. ${ }^{98}$

At the same time, both supporters and critics point out several problems. One concern is the lack of coordination among foundations and other donors that resulted in overlaps, duplications, and inefficiencies in the use of funds. While foundation funds moved rapidly into Eastern Europe, the speed and the number of foundations involved inhibited coordination and cooperation that might have improved the effective use of funds.

Another concern relates to sustainability of the institutions and civil society organizations that foundations helped to create. Foundations and other donors helped establish the legal environment for non-profits, provided technical training and initial funding, and in several cases paved the way for the formation of local foundations in Eastern Europe. ${ }^{99}$ Some critics contend, however, that foundations did not adequately take into account the long-term viability of new civil society organizations and prepare them to develop strong local ties and partnerships, capable local boards and staffs, and effective links with business and government in their city, region or country. Such institutional capacity and what one observer calls "the state of mind" of organizational staff and leadership are essential to enable civil society organizations to make independent decisions and become independent financially from Western donors. ${ }^{100}$ These critics contend that foundations and other donors departed too soon, before civil society had taken root in many recipient countries, and left behind too many civil society organizations dependent on Western assistance. ${ }^{101}$ Thus, one important lesson of the Eastern European experience is the importance, not only of institutions and processes, but also of an indigenous democratic political culture that supports civil society institutions. 
Critics have further argued that foundations and NGOs did not adequately take into account the different local environments in Eastern Europe and, instead, "attempted to recreate Eastern European civil society in the American image". ${ }^{102}$ Some critics contend that foreign assistance helped create an American or Western-centric civil society that is not effectively integrated into the local environment. ${ }^{103}$ One analyst has found that a dependency relationship developed between the civil society sector in Russia and its external donors. This analyst notes that some foundation supported groups have been effectively been "indigenized" or integrated into the Russian scene but that, in general, differential compensation and working conditions as well as opportunities for travel and participation in international events separate the local NGOs from their own societies and orient them towards the donor community as opposed to local constituencies. As a result of this separation and because of long held cultural suspicions about outsiders, she argues, the Russian public remains suspicious of the activities and motives of international donors. ${ }^{104}$ This suspicion along with the Russian government's concern about possible political activities of NGOs and foundations contributed to the strict implementation of a 2006 law that required non-governmental organizations including foundations to obtain permission from authorities to continue operating in that country.

Nevertheless, with their focus on education and civil society, foundations identified important comparative advantages and niches for their work in Eastern Europe and contributed to the transition process. They left many lasting institutions and influenced many current scholars and leaders. As one study concluded: "Foundations certainly cannot take all the credit or all the blame for the current situation. Nonetheless, foundation initiatives and involvement have had a positive effect on NGO development. While the sector would have expanded without the attention of foundations, the rate and scale of expansion was stimulated by their involvement." 105

\section{GLOBAL CHALLENGE: PEACE AND SECURITY}

U.S. foundations have supported programs to promote peace and security since the days of Andrew Carnegie. After 1989, foundations shifted their funding from Cold War conflicts to managing new security threats.

\section{International Security Studies}

Foundations have supported policy oriented research on security. In 1991, for example, the Carnegie Corporation created the Committee on Prevention of Proliferation whose members included Senators Sam Nunn and Richard Lugar and future Secretary of Defense William Perry, all of whom became major players in controlling nuclear proliferation. In 1994, Carnegie created the Committee to Prevent Deadly Conflict to consider how to prevent deadly ethnic, nationalist, and religious violence such as that in the former Yugoslavia and Rwanda. MacArthur has funded universities and research centers in the United States and abroad to work on non-proliferation, biological and chemical weapons, bioterrorism and cyber terrorism, and arms races in space. ${ }^{106}$ In 2009, MacArthur created an Asian Security Initiative to study how to strengthen regional cooperation and prevent conflict in Northeast Asia and develop international cooperation on transnational challenges including energy, natural disasters, and violent conflict. ${ }^{107}$

At the same time, several foundations have helped shape the foreign policy agenda and debate in a different direction. Conservative foundations including the Lynde and Harry Bradley, John M. Olin, 
Smith Richardson, and Sarah Scaife foundations have long supported conservative think tanks that have had an important influence on U.S. domestic and foreign policy. During the Cold War, neoconservative scholars and policy analysts at institutions like the American Enterprise Institute, the Hudson Institute, and the Heritage Foundation advocated support for anti-communist governments abroad and a strong U.S. military at home, and expressed skepticism about international organizations, international law, and multilateralism in general. Since 1989, the neoconservatives have advocated using American influence and power to advance U.S. concepts of democracy and market economies abroad. A number of neoconservatives who worked in institutions supported by the conservative foundations were appointed to important positions in the George W. Bush Administration and helped shape that administration's foreign policy. ${ }^{108}$

\section{International Dialogues}

In addition to supporting security studies, foundations have also funded international dialogues. One type of dialogue, which dates back to the Dartmouth conferences of the 1950 s and David Hamburg's diplomacy with Mikhail Gorbachev in the mid1980s, is Track II diplomacy. Unlike government-to-government or Track I diplomacy, Track II involves unofficial and informal contacts among private individuals whose purpose is to open communication, build confidence, or explore solutions in adversarial situations. Track II diplomacy provides a way to establish contact and dialogue when governments are in serious conflict or when they do not have official relations with each other. This private diplomacy may provide an alternative diplomatic channel that has no official standing. While it can make no official commitments, it can sometimes contribute to problem solving.
Most often, Track II consists of a series of small meetings organized around a set of issues. The participants are usually influential private sector leaders and often include former government officials acting in their personal capacity. Representatives at such meetings inform their governments about their discussions and governments may informally support such meetings and use them to learn about the other side, test ideas, or send messages to foreign governments. Sometimes, government officials participate in this private diplomacy, known informally as Track $1 \frac{1}{2}$. Track II initiatives are privately funded, involve efforts over long periods of time, and are difficult to evaluate. ${ }^{109}$

Several recent Track II initiatives have addressed the threat of nuclear proliferation posed by North Korea and Iran. The Carnegie Corporation and other foundations have supported a bilateral dialogue between the U.S. and North Korea run by the National Committee on American Foreign Policy that complements the six party official talks addressing North Korea's nuclear program. This Track II effort, which began in 2003 and is ongoing, meets about once a year. While participants have changed from meeting to meeting, participants have at times included high level North Korean representatives to the United Nations and other high level Korean representatives, former senior U.S. government officials including former Secretary of State Henry Kissinger, former U.S. Ambassadors to China Stapleton Roy, Winston Lord, and James Lainey, and former Ambassador and State Department Counselor Wendy Sherman, senior Republican and Democratic staff from the Senate Foreign Relations Committee as well as experts and Carnegie Corporation officers. Its goal is: "To explore and build support for cooperative multilateral means of assuring a denuclearized Korean Peninsula, developing an appropriate verification regime, and integrating North Korea

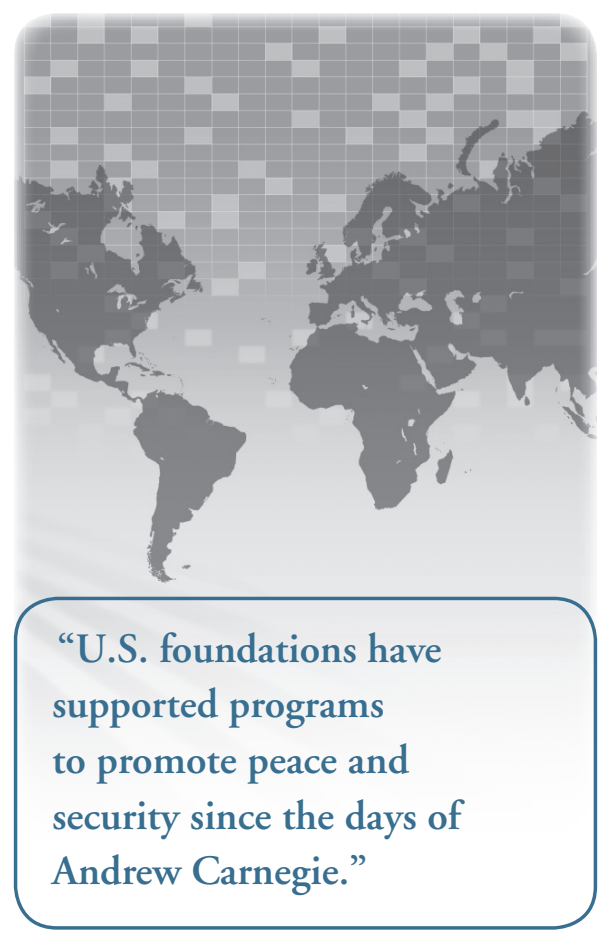


“Track II diplomacy provides a way to establish contact and dialogue when governments are in serious conflict or when they do not have official relations with each other."

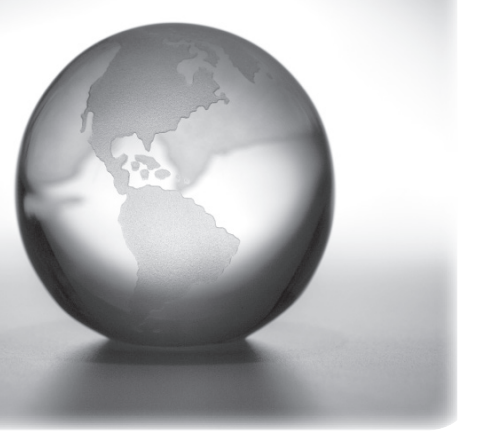

into the global community." ${ }^{110}$ Subjects addressed in this senior level dialogue range from broad strategic issues to specifics such as mechanisms for verification and the design of a formal entity to implement an eventual agreement.

Carnegie and others have also funded other Track II or Track 1 1 $1 / 2$ efforts involving North Korea. One is the Northeast Asia Cooperation Dialogue, a multilateral forum that has met regularly since 1993 . Its participants include current and former diplomats and defense officials as well as academic experts from the six parties involved in the official talks. ${ }^{11}$ This multilateral dialogue covers a variety of issues of concern to the six countries and provides yet another forum to discuss the North Korean nuclear issues that are addressed in the bilateral U.S.North Korean discussions. These and other dialogues have kept the channels of communication with North Korea open despite the absence of formal diplomatic relations and even when formal government to government talks have stalled.

A Track II dialogue with Iran was initiated by the Rockefeller Brothers Fund and the United Nations Association of the United States. After September 11, 2001, RBF's president explored how the foundation might contribute to better relations in the Middle East. The conclusion was that Iran was a key to the future of the region. The United States had no diplomatic relations with Iran and relations were tense due to Iran's nuclear program and its suspected sponsorship of terrorist groups in the region. So, in late 2001, RBF and UNA-USA initiated a Track II initiative as a way to open communications; build mutual knowledge, communication, and trust; and develop ideas for improving relations.
After a year of preparations, the first meeting took place in December 2002 in Sweden, where it was hosted by the Swedish International Peace Research Institute. The chair of SIPRI, Rolf Ekeus, who is a former Swedish diplomat and senior U.N. official and an expert on disarmament, participated in the meetings. American participants included Stephen Heintz, president of RBF; William Luers, president of the United Nations Association and a former senior State Department official; and other former senior U.S. government officials and arms control experts. Iranian representatives included academics and policy advisors, most representing reformist groups in Iran.

The U.S. side met regularly with high level officials at the State Department, National Security Council, and White House, as well as with key members of Congress. Senators and representatives occasionally attended meetings in Sweden. In between meetings, the Americans were in regular touch with Iran's Ambassador to the United Nations, who played a central role launching and managing the dialogue. Prior to the election of Mahmoud Ahmadinijad as President of Iran in 2005, the Iranian side also met with its government representatives, but this contact lapsed after the 2005 change in government. Ekeus served as a communication channel to European governments.

Between 2002 and 2008, there were 14 dialogue meetings, most in Sweden. Each meeting included a discussion of the domestic context in each country, review of Iran's nuclear program, and discussion of terrorism. In 2006, after extensive negotiation, the group agreed on a joint paper that identified both common ground and areas of difference between the two countries and suggested options for improving the relationship, including government-to-government negotiations. The proposal for official negotiations was resisted 
by conservative elements in both governments, especially after the election of a hard line government in Iran in 2005. ${ }^{112}$ There have been no Track II meetings since 2008. ${ }^{113}$

As an evaluation of the U.S.-Iranian dialogue concluded, the impact of that and other Track II dialogues depends on the overall political environment in which the dialogue takes place, the access of those engaged in the dialogue to decision makers in their respective governments, and the links between the private dialogue and official negotiations. ${ }^{114}$

\section{Impact}

Since the Second World War, foundations have contributed to the intellectual infrastructure of U.S. foreign policy by funding studies on peace and security. They have also supported international dialogues on the proposition that ongoing contact with adversaries promotes peace and stability over the long term and cannot be expected to yield early or even concrete results. However, the relative amount of funding for such work has declined in recent years as foundations have expanded their on the ground work abroad. The issue today is whether foundations are doing enough to help prepare the United States for the new global world with new threats to global security through their funding of studies, scholars, and practitioners of foreign policy as well as through international exchanges and dialogues.

Examination of the growing role of foundations as global players raises three questions. First, what impact do foundations have on the issues they are addressing: reducing poverty and global health inequities, building democracy and liberal market economies, controlling global warming and nuclear proliferation? Are foundations using their money wisely and well and are they contributing to the public good and improving the human condition? Second, what role are foundations playing in the global system and specifically in the governance or management of the system? And third, to whom are foundations accountable as they expand their international activities and their role in global governance? 



\section{ISSUES IN INTERNATIONAL \\ PHILANTHROPY}

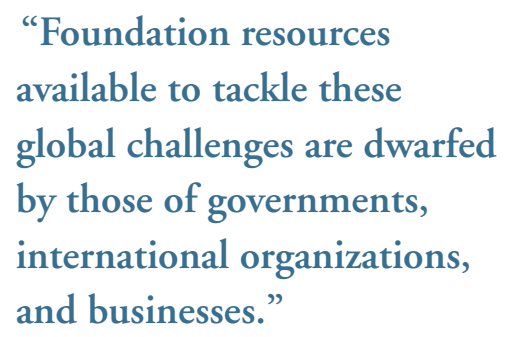

\section{IMPACT}

Global challenges such as health, poverty, climate change, democracy and nuclear proliferation are complex problems that resist change and depend on many uncontrollable factors.

Foundation resources available to tackle these global challenges are dwarfed by those of governments, international organizations, and businesses. Clearly, such problems cannot be solved by foundations alone, if they can be solved at all.

What foundations can do is to identify gaps, needs, and niches where their resources can contribute to pieces of the problem, to aspects of social, economic, and political change, as they have tried to do with support for education and civil society groups, ClimateWorks advocacy or with Track II diplomacy. They can try to leverage their funds with those of other foundations, governments, and business to maximize their impact as they have done with public private partnerships like IAVI and ACHAP. And they can try to identify innovative or experimental ideas and solutions to problems that, if successful, can be adopted and sustained by governments, multilateral organizations, or other funders as with pilot programs to address poverty in developing countries. So the question is: what is the impact of these individual programs?

Measuring success and evaluating specific foundation programs has special challenges. Unlike business, philanthropy has no marketplace or financial measure of success. Unlike other non-profit organizations, it is not tested by having to raise private or public funds. Many foundations conduct evaluations of their programs to determine if they are meeting their objectives by using surveys, external evaluators, and outside review panels. Some foundations apply business-style metrics to their work. They create strategic and operational plans, set objectives and milestones, focus on outcomes, and gather data to evaluate their work. The Gates Foundation, in particular, is known for using such a business approach to evaluation. There are distinct advantages in setting clear objectives and devising ways to measure progress and evaluate success. Defining common objectives and measurements may be especially important in joint ventures or partnerships. Understanding how public-private partnerships have worked and developing criteria for best practices could well improve future such ventures. ${ }^{15}$

However, some programs may be difficult to measure. The results of programs to develop leaders or civil society, for example, can only be known over the long haul and with years of longitudinal data. Furthermore, a focus on measurement might lead foundations to be too short-term oriented or to focus on programs that are measurable but not important. Collection of longitudinal data, on the other hand, may be costly and unproductive. ${ }^{116}$

Most major foundations ask themselves these questions about their own programs. They consult experts in relevant fields, confer with other foundations on strategies and evaluations, and engage consulting firms that measure various aspects of foundation performance. ${ }^{117}$ There have 


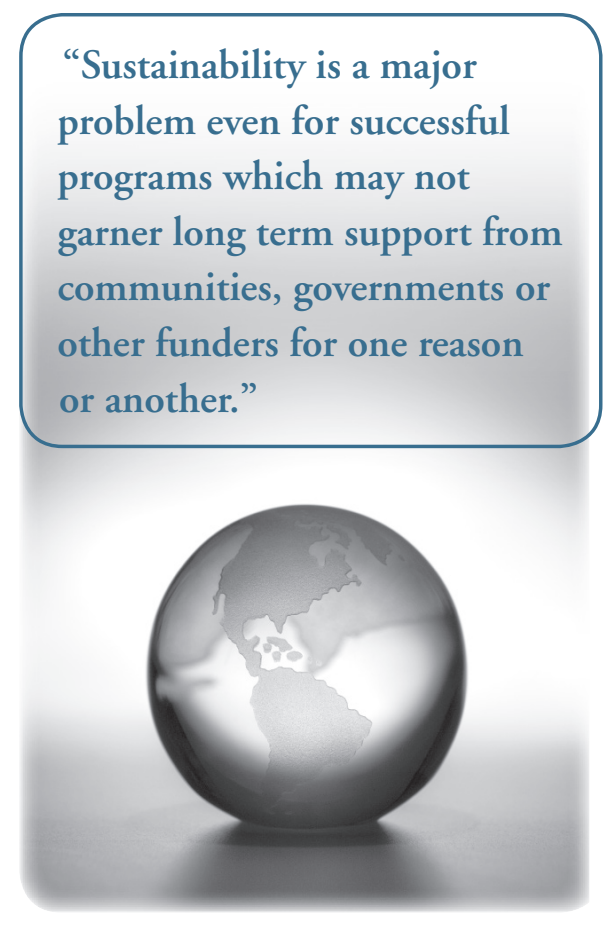

also been some academic studies of international programs of foundations. Several universities including Indiana, Harvard, and Duke have centers of philanthropy. There are scholars who specialize in philanthropy and some excellent studies of the international role of philanthropy in general and in particular issue areas. ${ }^{118}$ Aside from those who specialize in the study of philanthropy, there has been little academic interest in the international role of foundations and philanthropy. While there has been growing attention to transnational civil society, there has been only limited examination of the role of foundations in U.S. foreign policy and the global system. ${ }^{119}$

Foundation evaluations and academic studies suggest, not surprisingly, that some programs are successful; others are not. Foundation programs may be well informed and responsive to local cultures and needs, or may be misguided and insensitive; foundations may take the long view or be short sighted. Programs may be focused and strategic, or scattered and quirky; foundations may be efficient or inefficient in their use of resources; they may be fortunate and align with forces of change or they may not. Sustainability is a major problem even for successful programs which may not garner long term support from communities, governments or other funders for one reason or another. In some cases, U.S. foundations have nurtured local philanthropy in an effort to assure sustainability. In other cases, foundations may create dependency relationships in which constituencies come to rely on foundation financing and foundations are faced with the dilemma of devising exit strategies or making long term commitments.

Foreign policy experts including government officials, policy analysts, and other practitioners pay little attention to foundations. ${ }^{120}$ Perhaps that is because of the low profile of foundations, perhaps because they feel it is not possible or appropriate to influence foundation policies. The role of foundations as funders of scholarly and policy work may also discourage evaluation, study, and critique of foundations. Actual or potential recipients of foundation funding may be reluctant to question or criticize foundation policies. Foundations have understandably been concerned about maintaining their independence and autonomy and not encouraging government, in particular, to interfere with their policies and programs. But discussion and even challenge especially from academic and public policy institutions outside the world of foundations would be healthy and could well strengthen foundations and improve their work. Foundations, foreign policy experts, and practitioners would benefit from greater transparency, discussion, dialogue, and debate about the role of foundations in the global system and in U.S. foreign policy.

\section{GLOBAL GOVERNANCE}

Another central question is the role of foundations in global governance. ${ }^{121}$ As we have seen, private foundations have long been a valuable asset for the United States supporting the intellectual infrastructure of American world leadership at home and advancing American values, interests, and influence abroad. They have also been a distinctive American asset. Although new foundations are being created outside the United States and the international role of non-U.S. foundations is growing, no other country yet has private foundations with the resources and international reach of American philanthropy.

Foundations have long contributed to American "soft power," which is the ability to co-opt people rather than coerce them with force and "hard power." Foundations enhance America's image and reputation abroad and promote American values such as pluralist democracies and liberal economies. They also 
promote changes abroad that align with American interests and advance American objectives. ${ }^{122}$ Foundations have contributed significantly to the intellectual infrastructure of American foreign policy, helped build ties between Americans and their foreign counterparts, fostered American values such as pluralist democracies, liberal economies, and respect for human rights. This is not to say that foundation strategies always strictly conform to official American foreign policy. American foundations have supported programs that were contrary to official U.S. policy on apartheid; human rights policies in Latin America; and support for a global climate regime. History suggests that foundation strategies such as these sometimes preceded what turned out to be changes in official U.S. foreign policy.

Apart from contributing to American soft power, foundations also play a growing role in global governance, that is, the formal and informal institutions, laws, processes, and values that guide international relations. In the postCold War era, issues high on the global agenda have expanded beyond traditional national security problems to include many problems addressed by private philanthropy_addressing health inequities and poverty, supporting democracy and human rights, preventing climate change and nuclear proliferation. Building on the early vision and practice of Rockefeller, Carnegie, and Ford, today's foundation leaders see these problems in global, not just American terms; seek to address them on a worldwide scale; and have directed considerable resources around the world to that end.

Of course, foundations, perhaps with the exception of the Gates Foundation, do not have the financial or human resources, or the political power of governments and international organizations. Nevertheless, they have advantages and strengths in addressing today's global issues. In particular, they have independent financial resources and are to a great extent independent of government. Because foundations have their own resources, they do not have to contend with legislative processes or government bureaucracies — although large foundations may have their own bureaucracies. Thus, foundations can take economic risks with their own funds, for example, by supporting new or untested approaches to HIV/ AIDS or tropical diseases and funding new climate change institutions abroad. Unlike many government and international organizations, foundations primarily use their money to make grants, not loans, so their potential benefits may be greater.

Independence also enables foundations to take political risks that governments cannot or will not take. They supported dissidents and intellectuals in Eastern Europe in the 1970s and 1980s, funded legal challenges to apartheid in South Africa starting in the 1970s, and helped human rights groups in Latin America in the 1970s and 80s. Foundations supported work on AIDS at home and abroad when those with the disease were stigmatized; they pushed for public policies to address climate change when the U.S. federal government denied there was a problem of global warming; and they established a dialogue with Iran when the U.S. and Iranian governments were not talking directly to each other.

Foundations can also be nimble and act more quickly than government. They moved rapidly into East and Central Europe after 1989 to support scientists and intellectuals and help build civil society. They were ahead of government in addressing the HIV/AIDS pandemic in developing countries. More important, foundations are free to take the long view and can be patient funders. They are making long-term investments in medical research on HIV/AIDS and diseases of developing countries as well as in studies of conflict resolution and 
non-proliferation. They have funded civil society and human rights abroad, and have battled global warming despite little promise of early returns on their investments. Foundations have also supported and directly engaged in private diplomacy over long periods of time, seeking to build confidence and even devise solutions to conflicts, even when prospects were not promising, as has been the case with North Korea and Iran.

Foundations are able to engage directly with foreign societies and polities where it is often inappropriate, difficult or impossible for government to reach. While governments and international organizations most often work in one way or another through other governments, foundations or their grantees can work directly with civil society organizations and individuals abroad. Foundation policies are grounded in and shaped by a fundamental philosophy characteristic of the American political culture: belief in the legitimacy and desirability of private funding for public good and in the central role of civil society as a balance to government and business, and as a basis for pluralist democracy. Foundations often see individuals or members of civil society, not governments, as their allies and clients. That is why foundations have worked to build the capacity of the non-profit sector around the world. They have funded national civil society organizations as in Eastern Europe, regional organizations such as the European Climate Foundation, and global groups or networks as with ClimateWorks.

Foundations have also helped develop new models of international cooperation including alliances, partnerships, and networks of governments, international organizations, nonprofits, other foundations, business, and individuals. Sometimes, foundations are closely involved with foreign governments. In Eastern Europe, foundation grantees developed legislative proposals for governing civil society organizations. The Energy Foundation in China works with the Chinese government to develop and implement policies for energy use. ACHAP includes the government of Botswana as a partner. Sometimes, foundations bypass local governments or support groups that challenge or oppose governments as in communist Eastern Europe, apartheid South Africa, and HIV/AIDS work in South Africa. Sometimes they avoid governments that are seen as corrupt and work instead with local and international civil society organizations.

Foundations have created new entities and acted as catalysts for multinational and multi-sector cooperation on global issues, as with IAVI, AGRA, and the Energy Foundation. They have created and supported networks of nongovernmental organizations that share ideas, strategies, and coordinate action, as with ClimateWorks. Foundations also engage in private diplomacy. Through Track II diplomacy and various forms of private diplomacy, they foster and participate in private international networks of experts to address conflicts, build trust, and even advance solutions to thorny problems.

Finally, foundations and the NGOs they support have helped to promote common global norms and values. By working to arrest global warming, support people living with HIV/AIDS or build civil society, foundations bring visibility to these issues, help to put them on national and international agendas, and foster the development of common global norms and values.

All of these efforts enhance the management of globalization. Indeed, the model of the American private foundations is also becoming globalized. Foundations based outside the United States in both developed and developing countries are growing in number and size and becoming more active on the international scene. National governments, because of fiscal constraints and a growing belief in a 
liberal political order, are changing their laws and policies to promote the creation of private foundations; many U.S. foundations are encouraging and even incubating new private foundations abroad. Many old and new foundations are working together across national boundaries on global issues, including, for example, climate change and health.

\section{ACCOUNTABILITY}

The growing role of private foundations on the global scene raises a third important governance question: to whom are these independent and increasingly powerful organizations accountable? ${ }^{123}$

\section{At Home}

We have seen that U.S. foundations are to a great extent independent of government and that independence is an important and positive attribute that enables them to take risks, act expeditiously, pursue long-term strategies, and operate in ways that government cannot. At the same time, foundations operate within a legal, political, and social context and depend on the support of or acquiescence from the public and political system for their legitimacy and their privileged role. Independence will continue to be accepted as long as it is undergirded by the belief that foundations are responsible, responsive, and accountable to their various constituencies: the United States which charters and regulates them, foreign governments where they operate abroad, international organizations and nonprofits which are their partners, and the people around the globe whom they ultimately serve.

In the United States, the independence and legitimacy of American foundations is grounded in the U.S. political culture and the American belief in the important role of civil society in a plural democracy. Public laws give foundations privileged legal status and tax advantages; enable them to have endowments and therefore significant financial independence; and place some limits on the work they do. In return, foundations are expected to obey the laws and to serve the public interest broadly defined.

A central question, then, is how to hold foundations accountable for complying with public laws and serving the public interest. In the United States, public accountability has focused primarily on legal compliance. The IRS and state attorneys general regulate and oversee foundations and, appropriately, focus on financial accountability and malfeasance. Members of Congress and other public officials sporadically pay attention to foundations. Some have criticized compensation of foundation executives, proposed to alter philanthropic tax exemptions, require greater annual expenditures, or improve governance. ${ }^{124}$ Over the years, legislators have questioned domestic or international foundation policies and practices. One recent example occurred in the wake of the terrorist attacks of 9/11 when the Ford Foundation was accused of funding a Palestinian nongovernmental organization that advocated anti-Zionist and anti-Semitic policies. Despite publicity critical of Ford and threats from members of Congress to examine Ford's tax-exempt status, in the end, the crisis was settled when Ford agreed to include language in its grant letters requiring grantees to affirm that neither they nor their subgrantees promote or engage in violence, terrorism, bigotry or the destruction of any state. ${ }^{125}$ Despite periodic controversies, there has been no fundamental challenge to foundation legitimacy in the U.S.

Transparency is an important aspect of public accountability. Over time, foundations have disclosed more information about their finances and programs. Some disclosure has been mandated by regulatory authorities, as with the extensive tax reports required for private foundations;

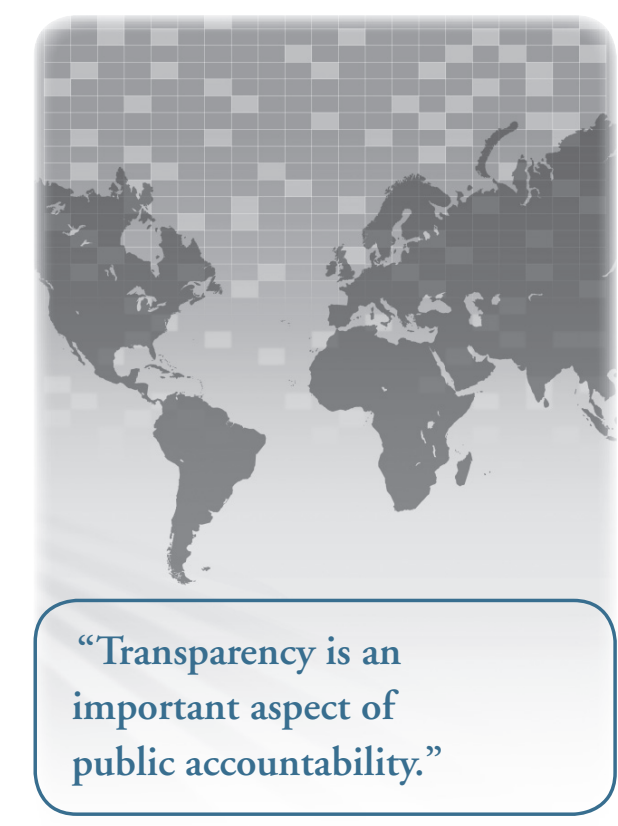




\section{"As international}

philanthropy grows,

foundations need to be

knowledgeable about and

sensitive to their impact on

foreign societies, polities,

and governments." some has emerged voluntarily in response to public and congressional interest or controversy. ${ }^{126}$ Foundations increasingly provide information about their finances and grants and make available studies and critiques of their work in annual reports and on websites. Third parties also provide information. Since 1956, the Foundation Center has gathered, analyzed, and made public data on foundation grants and policies and has recently launched a "Glass Pockets" initiative to increase disclosure of foundation policies. GuideStar, a nonprofit organization, also provides tax and other financial data about foundations and other nonprofit entities. Foundations and third parties should continue and expand such disclosure and reporting.

Attention to foundations is unfortunately limited among the other institutions that serve as checks and balances in the American political system. Although the purpose of foundations is to serve the public good, the press, academia, think tanks rarely examine whether they are going about that work wisely and well. The press pays little attention to foundations. Traditionally, foundations have shunned visibility, preferring to give attention and credit to grantees. There are discussions and debates in the philanthropic press about foundation policies and practices although very little about international programs. Otherwise, the media has shown little interest in foundations except in cases of misconduct or of mega foundations with well known benefactors such as the Gates Foundation. Only rarely are foundation programs and policies covered by the media. As we have noted, academia and think tanks, with some exceptions, pay little attention to international philanthropy. Finally, there are few "watch dog" organizations in the philanthropic world. The National Committee for Responsive Philanthropy and the Capital Research Center offer critiques and spark debate. Again, little attention is paid to global work. Foundations should encourage and fund policy and research institutions as well as watch dog organizations to analyze and critique their international strategies and programs.

\section{Abroad}

Accountability for activities of U.S. foundations outside the United States is more complicated and problematic. American foundations are chartered and regulated in the United States, but they increasingly operate outside American borders, often in political and social environments where the role and legitimacy of civil society is quite different from the U.S. The goals of foundations when operating abroad, like their domestic goals, are to pursue social change. As we have seen, they seek to empower civil society organizations, foster the rule of law, influence policies of governments and international organizations on climate change, and change the systems and policies of health care and AIDS treatment. Thus, in one way or another, foundations are advocates, activists, and political players in foreign environments. They deploy significant resources and therefore possess influence and exert power in these foreign environments.

As international philanthropy grows, foundations need to be knowledgeable about and sensitive to their impact on foreign societies, polities, and governments. What does that mean in practice? Most foundations are committed to improving the human condition and want to be sensitive to local needs and local cultures. Yet there is little discussion among foundations let alone with those outside the foundation world about standards of behavior when operating abroad. What guidelines should they use outside their home country? Are there special criteria for risky or sensitive work such as supporting human rights organizations that challenge local governments? Are foundations adequately transparent 
about their work in foreign countries? What disclosure requirements should there be in foreign countries about their activities? Do foundations comply with local laws and policies? Do they work with local players? Have they consulted local constituencies and built on local support for their work? Have they helped to build local capacity and local institutions or have they funded international nonprofits to the disadvantage of local entities?

Are foundations sensitive to or aware of their power and influence in foreign settings? How do various foreign constituencies-governments, international organizations, nonprofit organizations and individuals_-judge the work of philanthropy abroad? Do they find it positive or negative, helpful or irrelevant, efficient or wasteful, supportive or intrusive?

Foundations and their grantees also need to understand better any unanticipated impacts they have on societies abroad. As foundation support grows within particular sectors, that funding may shape or distort the local system. For example, philanthropic support for AIDS and other infectious diseases in developing countries has increased significantly, but it may have distorted health care resources and delivery, drawing resources from primary health care, and burdening a broken public health system. Foundation support for civil society may advance an America centric view of political culture which may or may not be in keeping with local cultures. External funding may create civil society groups that are dependent on foreign assistance and that lack close links to their local society. ${ }^{127}$

Critics have contended that foundations with divergent reporting and expenditure requirements place unnecessary burdens on recipients and create waste and duplication. Some foreign government officials and grantees express concern that they are overwhelmed by the demands and lack of coordination of donors, especially in the field of health, AIDS, and other neglected diseases where government and private funding has increased dramatically. Potential grantees are loathed to turn down funding, but wish foundations and their grantees were better coordinated. Are there models of best practices in working with governments in developing countries?

A final set of questions addresses the issue of sustainability. What happens if and when a foundation decides to exit a program or a country? For example, if other funders do not assume responsibility for ACHAP, can Gates and Merck exit Botswana? To what extent have grantees become dependent on foundation funding? As we have seen, critics have contended that aid to civil society organizations in Eastern Europe and Russia created dependent organizations that do not have adequate links to their home base. Have foundations considered how to ensure or at least increase the odds that successful projects they support will have the promise of long-term sustainability? How can they best encourage governments or other funders to be willing and able to assume responsibility for programs created by foundations? Have foundations considered how best to exit particular programs or grants without causing disruption? Have they developed local infrastructure and local partners and capacity or have they relied too much on outsider entities to conduct programs? Have they considered how pilot or demonstration programs could be taken to scale? Have efforts to promote indigenous foundations been successful?

As discussed above, one way that foundations can improve their international accountability is by supporting independent evaluations and making them available to the outside world. Another way is to assure strong internal governance, particularly at the board level. Foundation staff, however knowledgeable and self 


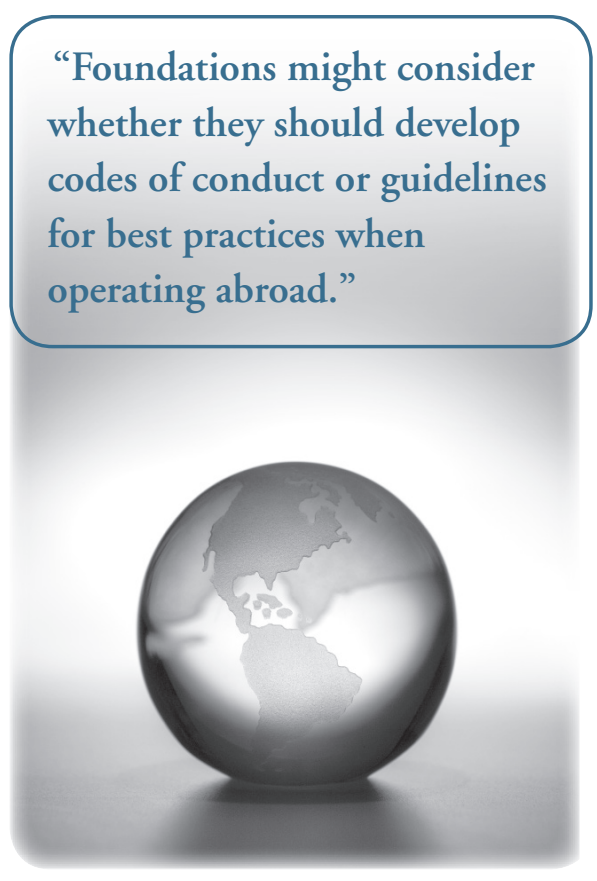

critical, are hampered by the absence of competition and criticism in the philanthropic environment where grant seekers and many others are often reluctant to be honest and critical. ${ }^{128}$ Foundation boards are ultimately responsible for strategies, policies, and programs as well as for financial, regulatory, and legal compliance. Board members should take those responsibilities seriously, respecting but challenging staff, requiring external evaluations, and involving outside experts. Boards should consider their own composition and ways of operating in order to assure adequate oversight.

Foundations should also consider the merits of self regulation, particularly codes of conduct and ethics, in their international activities. As civil society groups have become prevalent and active worldwide, more engaged in advocacy, and therefore more in the public eye, there have been numerous efforts to develop techniques of self regulation. Self-regulation responds to public concerns about financial and program accountability especially for NGOs that must raise funds as well as a desire to deflect initiatives for government regulation. Self-regulation, thus, may be a way of "building public trust, protecting the political space for [NGOs] to operate, and sharing good practice and learning." 129

Foundations might consider whether they should develop codes of conduct or guidelines for best practices when operating abroad and what those might be. A joint working group of the Council on Foundations and the European Foundation Center, for example, produced a set of general principles that emphasize understanding, respect for, and engagement with international grantees and partners. ${ }^{130}$ Another example is a code of conduct for NGOs working on health systems. It was developed by several NGOs in the health field that were concerned about the weaknesses of health systems in developing countries and the distortions caused by foreign assistance in AIDS and health. The code addresses issues of sustainability, compensation and hiring practices, as well as relations with Ministries of Health, governments, and the public sector. ${ }^{131}$

Such codes might be combined with or complemented by techniques for monitoring compliance or assessing accountability by third parties. Such assessments of social responsibility are becoming more common in the commercial world. For example, CERES, a network of investors, environmental organizations, and public interest groups, evaluates corporate performance on a variety of environmental indicators. ${ }^{132}$ Dow Jones has created a sustainability index that measures risk and crisis management, anti-corruption and bribery, ecoefficiency, human resources practices, environmental and social reporting, and environmental governance. ${ }^{133}$ The Global Accountability Project of One World Trust in the United Kingdom assesses thirty major corporations, intergovernmental organizations, and non-profit organizations-but not private foundations - every year on four criteria: transparency, participation, evaluation, and complaint and response mechanisms and issues a public report on their performance. ${ }^{134}$ None of these assessments is adequate or scientific, but they can provide a basis for comparison, analysis, and benchmarking of best practices. Foundations should consider whether and how these models might apply to their international philanthropy. 


\section{FUTURE GLOBAL CHALLENGES}

Foundations are already playing a role in many of today's significant global challenges. Looking ahead what global issues should they address in the future?

For example, can foundations play a role in addressing issues related to radical Islam and the relationship between the U.S., the West, and the complex and diverse Muslim world? The United States is woefully lacking in expertise about the Muslim world. Some foundations including Carnegie and Doris Duke have started to fund Islamic studies and analyses of contemporary Islam. Might foundations provide support for area or policy studies pertaining to countries and regions with significant Muslim populations of the type they pioneered during the Cold War? What about funding in these countries, which have vast needs for the type of work that foundations have long supported including education, development of civil society, and human rights? ${ }^{\text {?35 }}$ For example, while some foundations including the Ford Foundation work in the Middle East, many have been deterred from active involvement in that region due to the constraints of the Patriot Act and concern about involvement in highly politicized situations. ${ }^{136}$ Should foundations support civil society, human rights, or education programs in Muslim countries and, if so, how? The Department of State under Secretary Clinton, for example, has asked foundations for advice on designing programs to improve relations with the Muslim world. ${ }^{137}$ If foundations pursue programs addressing the Muslim world and failed states, should they relate their programs to those of the U.S. government, and, if so, how?

Similarly, what role might foundations play in failed states or post-conflict states? What have foundations learned from their work in South Africa and Eastern Europe? How are foundations faring in places like the Balkans and the Caucasus? In the future, as the United States withdraws from Afghanistan and Iraq, are there opportunities for foundations to play a role in those countries, not to replace aid or other foreign assistance, but to help build the infrastructure of pluralist societies, as they have tried to do elsewhere? The Ford and other foundations, for example, created the International Center for Transitional Justice that works on achieving justice and reconciliation in countries in subSaharan Africa that have experienced human rights abuses and mass atrocities. How has it worked and can more be done?

Another issue is preparing the United States at home for the new global world. How should foundations invest in American intellectual capital? Can foundations contribute to policy work including the future of national security policy, military strategy, diplomacy, and international institutions for the new global era? While foundations have long supported education, training, and analysis at home, recent funding has increasingly been directed abroad. Foundation support has often gone to specific projects and issues not to general support for foreign policy studies or public policy institutions. Should U.S. foundations be giving more support for this intellectual infrastructure? What about support for public education? Should foundations promote broader public understanding about and knowledge of global issues? What is the right balance of foreign and domestic investments?

Foundations have formed partnerships with governments, international organizations, and businesses and there is much talk of "public-private partnerships" as a new form of global management. What have we learned from these partnerships and networks? How do the various players-governments, international organizations, businesses, NGOs, and foundations - judge these partnerships? When does it make sense to form partnerships? What are best practices for developing, managing, and evaluating partnerships?

Another issue relates to philanthropy originating outside the United States. Until recently, American foundations were virtually the only international players, which has been a significant asset for American foreign policy and American influence. During the transition from communism in Europe, many European foundations became involved for the first time outside their borders. Now, new philanthropies from Europe, the Middle East, and Asia are being formed and some are working abroad. In fact, many American foundations are encouraging the creation and development of philanthropies outside the United States. What are these new organizations doing and how does their work relate to American foundations and U.S. national interests? What is their relationship with their own governments?

\section{CONCLUSION}

The strength and value of foundations flows from their independence, but that independence derives from serving the public good. Foundations need critically to examine and evaluate their roles and responsibilities in serving the public good when operating abroad. The foreign policy community, for its part, should pay greater attention to the growing international role of foundations and should engage them in greater discussion, analysis, and debate about international strategies. These efforts would enlighten and challenge foundation boards and staff to improve their international work and thereby serve both U.S. and global interests and improve global governance. That, in turn, would help realize the ultimate objective of foundations: improving the human condition. 


\section{Endnotes}

1. The term "private foundation" is based on U.S law. The term "foundation" is commonly used for many types of organizations in the United States. Other organizations called foundations such as the Carter, Clinton, and United Nations Foundations have a different legal status as "public charities". They make grants and serve the public good but they raise funds from multiple sources and do not rely solely on their own financial resources. Corporations also have "foundations" that are usually not endowed and are funded from company resources.

2. There are a number of important recent studies on the role of foundations in the United States, including: Helmut K. Anheier and Diana Leat, Creative Philanthropy (London and New York: Routledge, 2006); William Damon and Susan K. Verducci, editors, Taking Philanthropy Seriously: Beyond Noble Intentions to Responsible Giving (Bloomington and Indianapolis: Indiana University Press, 2006); Peter Frumkin, Strategic Giving: The Art and Science of Philanthropy (Chicago and London: University of Chicago Press, 2006); Joel L. Fleischman, The Foundation: A Great American Secret: How private wealth is Changing the World (New York: Public Affairs, 2007); Lawrence J. Friedman and Mark D. McGarvie, Charity, Philanthropy, and Civility in American History (Cambridge: Cambridge University Pres, 2003). Kenneth Prewitt, Mattei Dogan, Steven Heydemann, and Stefan Toepler, eds., The Legitimacy of Philanthropic Foundations (New York: Russell Sage, 2006).

3. The major foundations in this study are: Carnegie Corporation and the Doris Duke, Bill and Melinda Gates, Ford, William and Flora Hewlett, W.K. Kellogg, John D. and Catherine T. MacArthur, David and Lucille Packard, Andrew W. Mellon, C.S. Mott, Open Society Institute, Rockefeller, and Rockefeller Brothers foundations.

4. See Luc Tayart de Borms, Foundations: Creating Impact in a Globalised World (West Sussex: John Wiley, 2005), pp. 27-51 for a comparison of European and American models of civil society. Andreas Schluter, Volker Then \& Peter Walkenhorst, eds. Foundations in Europe: Society, Management, and Law (London: Directory of Social Change, 2001).

5. Luc Tayart de Borms, Andreas Schluter, Volker Then, and Peter Walkenhorst, eds., Foundations in Europe: Society, Management, and Law, (London: Directory of Social Change, 2001). OECD, Development Assistance Committee, Philanthropic Foundations and Development Co-operation, DAC Journal 2003, Volume 4, No. 3, pp. 3-36; Kenneth Prewitt, Mattei Dogan, Steven Heydemann, and Stefan Toepler, eds., The Legitimacy of Philanthropic Foundations: United States and European Perspectives (New York: Russell Sage Foundation, 2006).

6. Ron Chernow, Titan: The Life of John D. Rockefeller, Sr. (New York: Random House, 1998), pp. 37-61; 299-329 and 561-70; Raymond B. Fosdick, The Story of the Rockefeller Foundation (New York: Harper \& Brothers, 1952)

7. For a history of the concepts of charity and philanthropy see Robert A. Gross, "Giving in America: From Charity to Philanthropy," in Lawrence J. Friedman and Mark D. McGarvie, eds., Charity, Philanthropy, and Civility in American History (Cambridge: Cambridge University Press, 2003), pp. 29-48. For the emergence of the role of private foundations in the United States see also: Barry D. Karl and Stanley N. Katz, "The Private Philanthropic Foundation and the Public Sphere 1890-1930," MINERVA, Vol. XIX, No. 2 (Summer 1981), pp. 236-270.

8. See David C. Hammack, "American Debates on the Legitimacy of Foundations" in Kenneth Prewitt, Mattei Dogan, Steven Hydemann, and Stefan Toepler, eds., op cit. pp. 49-98.
9. As noted at footnote 1 above, private foundations have a different legal status than other types of foundations. See: David M. Schizer, "Subsidizing Charitable Contributions: Incentives, Information and the private pursuit of Public Goals", draft paper, February 22, 2008; Kenneth Prewitt, "American Foundations: What Justifies Their Unique Privileges and Powers" in Kenneth Prewitt, Mattei Dogan, Stephen Heydemann, and Stefan Toepler, eds., The Legitimacy of Philanthropic Foundations (New York: Russell Sage, 2006), pp. 27-46.

10. See Emily S. Rosenberg, "Missions to the World: Philanthropy Abroad," in Lawrence J. Friedman and Mark D.McGarvie, Charity, Philanthropy, and Civility in American History (Cambridge: Cambridge University Press, 2003), pp. 241-257. Joseph C. Kiger, Philanthropists \& Foundation Globalization (New Brunswick: Transaction Publishers, 2008).

11. See Raymond B. Fosdick, op cit.; Joseph Frazier Wall, Andrew Carnegie (New York: Oxford University Press, 1970), pp. 797-940.

12. Marxist and Gramscian critics have argued that this close relationship of elites was an integral part of the capitalist system and that American foundations were used by the dominant elite to export American culture and to secure American hegemony in the period after World War II. See, for example, Edward H. Berman, The Influence of the Carnegie, Ford and Rockefeller Foundations on American Foreign Policy: The Ideology of Philanthropy (Albany: State University of New York Press, 1983).

13. Report of the Study for the Ford Foundation on Policy and Program (Detroit: Ford Foundation, November, 1949). (Gaither Report) See also Gary R. Hess, "Waging the Cold War in the Third World: The Foundations and the Challenges of Development," in Friedman and McGarvie, pp. 320-321.

14. Ibid. p. 26

15. Ibid., pp. 52-61

16. Ibid., p. 71

17. For a criticism of such funding, see Bruce Cumings, "Boundary Displacement: Area Studies and International Studies during and after the Cold War," Bulletin of Concerned Asian Scholars 29(1) 1997. www.mtholyoke.edu/acad/intrel/ cumings2.htm Cumings criticizes what he sees as U.S. government and especially intelligence agency infringement on academic freedom and independence of universities and research institutes created by government funding of area and international studies during the Cold War. $\mathrm{He}$ argues that there were "astonishing levels of collaboration between the universities, the foundations, and the intelligence arms of the U.S. state."

18. Makoto lokibe, “U.S.-Japan Intellectual Exchange: The Relationship between Government and Private Foundations" in Yamamoto, pp. 61-98. Not mentioned here is the Asia Foundation which was active in funding civil society groups in Japan. In 1967 it was revealed that the Asia Foundation was a vehicle of the CIA.

19. Fosdick, p. 285.

20. Giuliani Gemelli and Roy MacLeod, eds., American foundations in Europe: Grant-Giving Policies, Cultural Diplomacy, and Trans-Atlantic relations, 1920-1980. (Brussels, New York : P..E.-Peter Lang, 2003).

21. Hess in Friedlander and McGarvie, pp. 322-323. On economic theory, see W.W. Rostow, "The Stages of Economic Growth," The Economic History Review, New Series, Vol. 12, No. 1, 1959, pp. 1-16 which was funded by the Ford Foundation and on political modernization see David E. Apter, The Politics of Modernization (Chicago: University of Chicago Press, 1969)

22. Fosdick, pp. 184-191.
23. Scott Kohler, "The Green Revolution" in Casebook for The Foundation, pp. 51-58; See below on the new Green Revolution. For discussion of critiques see: Rockefeller Foundation, President's Review and Annual Report 1970, pp. xix-xxviii; Peter B.R. Hazell, Green Revolution Reconsidered (Baltimore: Johns Hopkins University Press, 1991); Hazell Green Revolution: Curse or Blessing (Washington D.C: International Food Policy Research Institute, 2002)

24. Fosdick, pp. 231-233, Steven Schindler, "Curbing Global Population Growth: Rockefeller's Population Council," in Joel L. Fleishman, J. Scott Kohler, and Steven Schindler, Casebook for The Foundation : A great American Secret (New York: Public Affairs, 2007), pp. 70-72.

25. For a critical interpretation, see Edward $\mathrm{H}$. Berman, The Influence of the Carnegie, Ford, and Rockefeller Foundations on American Foreign Policy: The Ideology of Philanthropy (Albany, NY: State University of New York Press, 1981).

26. William Korey, Taking on the World's Repressive Regimes: The Ford Foundation's International Human Rights Policies and Practices (New York: Palmgrave McMillian, 2007), pp. 25-68.

27. Stephen Golub, "Battling Apartheid, Building a New South Africa" in Mary McClymont and Stephen Golub, eds, Many Roads to Justice: the Law-Related work of Ford Foundation Grantees Around the World (New York: Ford Foundation, 2000), pp. 29-54. Marita Golden, "Carnegie Corporation in South Africa: A Difficult Past Leads to a Commitment to Change," Carnegie Results, Winter 2004

28. See Simon Stacy and Sada Aksartova, "The Foundations of Democracy: U.S. Foundation Support for Civil Society in South Africa, 1988-96," Voluntas: International Journal of Voluntary and Nonprofit Organizations Vol. 12, No. 4 December 2001, pp. 373-397.

29. Korey, pp. 119-137.

30. Korey, pp. 89-117.

31. Scott Kohler "Support of Democratization and Civil Societies in Central and Eastern Europe: Open Society Institute and Soros Foundation Network," 1980, in Fleischman, pp. 156-62. Michael T. Kaufman, Soros: The Life and Times of a Messianic Billionaire (New York: Alfred A. Knopf, 2002), pp. 163-200.

32. Interview with and papers of David Hamburg.

33. See Berman, op cit.

34. See John Fonte, Teresa Odendahl, and John Earl Haynes, "Philanthropy and the American Regime: Is it tie for another congressional investigation of tax-exempt foundations?" Hudson Institute, November 30, 2004.

35. Foundation Center statistics.

36. The John D. and Catherine T. MacArthur Foundation 1993 Annual Report on Activities, p. 2.

37. www.rockfound.org

38. www.gatesfound.org

39. www.soros.org See Michael T. Kaufman, Soros: The Life and Times of a Messianic Billionaire (New York: Knopf, 2002), pp. 163-281.

40. Interviews with Carol Larsen, President of the Packard Foundation and Paul Brest, President of the Hewlett Foundation.

41. One indicator is the creation of the Global Philanthropy Forum. See www. philanthropyforum.org.

42. www.oecd.org/document/35/0,3343,fr_2649_34 487_42458595_1_1_1_1,00.html 
43. International funding by foundations has been part of a trend of growing participation of multiple new players in international giving including foundations, celebrities, corporations, and new official donors like China. See Lael Brainer and Derek Chollet, eds., Global Development 2.0: Can Philanthropists, the Public, and the Poor Make Poverty History? (Washington, D.C.: Brookings Institution Press, 2008).

44. WHO, Commission on Macroeconomics and Health, Geneva: WHO, 2001. United Nations General Assembly, Special Session on HIV/ AIDS, Declaration of Commitment on HIV/AIDS, June 27, 2001.

45. A few foundations continued to address problems of disease in developing countries. The Edna McConnell Clark Foundation, for example, funded research on tropical diseases from the 1970s to the 1990s. See Scott Kohler, "The Tropical Disease Program," in Fleischman et al, pp. 128-132.

46. Imagining a World without AIDS: A History of the International AIDS Vaccine Initiative, IAVI, 2006; http://www.iavi.org/history

47. ipm-microbicides.org

48. On Global Fund see: Anna Triponel, "Global Fund to Fight AIDS, Tuberculosis and Malaria: A New Legal and Conceptual Framework for Providing International Development Aid" in North Carolina Journal of International Law and Commercial Regulation, Fall 2009, No. 35, pp. 172-232.; Richard G.A. Feacham, Olliver J. Sabot, "An Examination of the Global fund at Five Years", Lancet Vol. 368, August 5, 2006, pp. 538-540

Another example of a public private partnership dedicated to treatment and prevention is The Global Alliance for Vaccines and Immunization. Created in 2000, GAVI is a partnership of foundations, civil society organizations, businesses, pharmaceutical companies, governments, and international organizations. Its goals are to bring existing and new vaccines and immunization technologies to developing countries and to strengthen health and immunization systems in those countries. GAVI began by distributing existing vaccines for influenza, yellow fever, and hepatitis to developing countries and is now also supporting the development of newe vaccines for pneumonia and diarrhea. GAVI does not focus on HIV/AIDS but it does help build the health infrastructure that will be needed if and when an HIV/AIDS vaccine is developed, and it may well play a role in eventual vaccine delivery.

49. See V. Kasturi Rangan, ACHAP (African Comprehensive HIV/AIDS Partnerships): The Merck/Gates Initiative in Botswana, Harvard Business School, 9-505-057, March 26, 2007.

50. See Tracy Kidder, Mountains Beyond Mountains: The Quest of Dr. Paul Farmer, the Man Who would Cure the World (New York: Random House, 2003).

51. www.achap.org/aids_in_Botswana

52. Approved by the government in 2001 , the plan laid out a five year agenda for implementing an ART program including: priority groups to receive treatment; recruiting and training healthcare workers and other staff; creating clinics and laboratories; public education; monitoring, evaluation, and operations research.

53. ACHAP Annual Report 2008

54. See Mark. R. Kramer, "Philanthropy, Aid, and Investment: Alignment for Impact," in Brainard and Chollet, pp. 216-224. On the importance of alignment with local governments see Linda M. Distlerath and Guy Macdonald, "Case Study: The African Comprehensive HIV/AIDS Partnerships-A New Role for Multinational Corporations in Global Health Policy," Yale Journal of Health Policy, Law and Ethics, Vol. 4, Winter 2004, pp. 147-155.

55. See Gates Foundation report on the problem of "absorptive capacity" www.gatesfoundation.org/ learning/Documents/ACHAP.pdf
56. See Ann Swidler, "Dialectics of Patronage: Logics of Accountability of the African AIDS-NGO Interface," in Hammack and Heydemann, op. cit, pp. 192-220.

57. See www.ddcf.org/Medical-Research/ProgramStrategies/African-Health-Research/ and www. rockefellerfoundation.org/what-we-do/currentwork/transforming-health-systems

58. Food and Agricultural Organization of the United Nations, Rapid Assessment of Aid Flows for Agricultural Development in Sub-Saharan Africa, Investment Centre Division Discussion Paper. September 2009, p. 4.

59. See David E. Bell and Brian Milder, "Alliance for (a Green Revolution in Africa AGRA)" Harvard Business School, N2-5-9-007, December 17, 2008. Interview with Sylvia M. Burwell, President, Global Development Program, Gates Foundation.

60. For discussion of critics, see David Rieff, "A Green Revolution for Africa?" The New York Times, October 12, 2008. For a positive assessment of privatization, see Carol C. Adelman, "The Privatization of Foreign Aid: Reassessing National Largesse," Foreign Affairs Vol. 82, No. 6 (November/December 2003), pp. 9-14.

61. Hewlett.org.

62. Gary H. Toenniessen, Director, Food Security. "Vitamin A Deficiency and Golden Rice: The Role of the Rockefeller Foundation", New York: The Rockefeller Foundation, November 14, 2000.

63. Rockfound.org

64. Foundation support for higher education discussed below in the section on democracy also contributes to economic development and eradication of poverty.

65. For discussion of history and evolution of the concept of "social entrepreneurship" see Michael Lounsbury and David Strang, "Social Entrepreneurship: Success Stories and Logic Construction," in Hammack and Seydemann, op. cit., pp. 71-94.

66. See Scott Kohler, "Grameen Bank," in Fleischman et al, pp. 137-141.

67. www.omidyar.com

68. Skollfoundation.org

69. For a critique of social entrepreneurship, see Michael Edwards, Just Another Emperor?: The Myths and Realities of Philanthrocapitalism (New York: Demos and the Young Foundation, 2008)

70. See website of Consultative Group on Biological Diversity for key environmental funders: cgbd.org.

71. In 2008, WRI, the Pew Climate Center, the Environmental Defense Fund and the Natural Resources Defense Council, joined a number of major U.S. businesses to form the U.S Climate Action Program or USCAP, a public-private partnership to press for climate legislation in the United States.

72. Jane Wei-Skillern and Alison Berkley Wagonfeld, "The Energy Foundation," Harvard Business School Publishing, 9-308-078, April 1, 2008.

73. Energy Foundation numbers.

74. See Energy in China: The myths, reality, and challenges, Energy Foundation Annual Report 2007.

75. California Environmental Associates, “Design to Win: Philanthropy's Role in the Fight against Global Warming," August 2007.

76. Discussion of Energy Foundation, CSEP, ClimateWorks, European Climate Foundation, Catalyst, also based on interviews with Andrew Bowman, Director of ClimateChange, Doris Duke Charitable Foundation; Eric Heitz, Executive Director, Energy Foundation; Paul Brest, President, Hewlett Foundation; Susan Bell, Vice President, Hewlett Foundation; Carol Larsen, President, Packard Foundation; Bradford Smith, President, The Foundation Center and former President, Oak Foundation, and Matthew Lewis, Communications Director, ClimateWorks.
77. I am grateful to Susan V. Berresford, former President of the Ford Foundation for suggesting this typology.

78. Scott Kohler, "International Fellowships Program," in Fleischman et al, pp. 269-271.

79. See, for example, Jonathan Fanton, "Announcement of the Initiative for African Universities", in Foundations and Civil Society, Volume Two (Chicago: John D. and Catherine T. MacArthur Foundation, 2008) p. 93-4; Stuart J. Saunders and Thomas I. Nygren, "A Review of the Foundation's Program in South Africa, 19882000," Mellon Foundation paper, June 15, 2001; Stuart J. Saunders and Susan Anderson, "A Review of the Foundation's Program in South Africa, 2001-2005", Mellon Foundation paper, September 2005

80. Stuart J. Saunders and Thomas I. Nygren, "A Review of the Foundation's Program in South Africa 1988-2000," Mellon Foundation, June 15, 2001, Stuart J. Saunders and Susan Anderson, A Review of the Foundation's Program in South Africa, 2001-2005, September 29, 2009.

81. Ford's support for several Palestinian legal and human rights groups led to a political uproar in the U.S. when two of those groups advocated language critical of Israel at a UN conference on racism in Durban, South Africa, in 2001.

82. www.internationalbudget.org

83. Simon Stacy and Sada Aksartova, "The Foundations of Democracy: U.S. Foundation Support for Civil Society in South Africa, 1988-96," Voluntas: International Journal of Voluntary and Nonprofit Organizations Vol. 12, No. 4 December 2001, pp. 373-397.

84. For the case in favor of funding for civil society, see Michael Edwards, Just Another Emperor? The Myths and Realities of Philanthrocapitalism (New York: Demos, 2008).

85. See Kevin F.F. Quigley and Nancy E. Popson "Rebuilding Civil Society in Eastern and Central Europe: The Role Played by Foundations" in Helmut K. Anheier and Stefan Toepler, eds., Public Purpose: Philanthropic Foundations in an International Perspective, (New York: Plenum Press, 1999) pp. 235-252. Miroslav Pospiscil, "Central and Eastern Europe" in pp. 21-35. One new development was the involvement of philanthropies from Western Europe.

86. For example, The National Institute for Democracy, a non-profit organization funded by the U.S. government, provided support to enable various civil society groups to prepare for elections in the former communist states.

87. www.state.gov/p/eur U.S. Department of State, Undersecretary for Political Affairs, Bureau of European and Eurasian Affairs, U.S. Government Assistance to Eastern Europe under Support for Eastern European Democracy

88. See Richard A. Quandt, The Changing Landscape in Eastern Europe: A Personal Perspective on Philanthropy and Technology Transfer (Oxford: Oxford University Press, 2002), pp. 60-67 on state of higher education in Eastern Europe. Interview with William G. Bowen, former President, Andrew W. Mellon Foundation.

89. See Richard A. Quandt, The Changing Landscape in Eastern Europe: A Personal Perspective on Philanthropy and Technology Transfer (Oxford: Oxford University Press, 2002), pp. 28-29.

90. See Kevin F.F. Quigley, For Democracy's Sake (Baltimore: Johns Hopkins University Press, 1997), p. 97-99; Scott Kohler, "Central European University” in Fleischman et al, pp. 212-217.

91. Quigley p. 94-5

92. Scott Kohler, "International Science Foundation" in Fleischman et al., pp. 228-231.

93. Quigley, pp. 19-21.; Quandt, pp. 130-139.

94. See Quandt pp. 139-155. 
95. See Richard E. Quandt op cit 156-250.

96. Quigley and Popson, p. 244-5;

97. Quigley, pp. 21-23

98. See e.g. Quandt and Quigley op cit.

99. See John. W. Slocum, “Philanthropic Foundations in Russia" in David C. Hammack and Steven Heydemann, eds., Globalization, Philanthropy, and Civil Society: Projecting Institutional Logics Abroad Bloomington and Indianapolis: Indiana University Press, 2009, pp. 137-159.

100. Quigley pp. 110-112

101. Kevin F. F. Quigley, “Lofty Goals, Modest Results," In Marina Ottaway, Thomas Carothers, eds., Funding Virtue: Civil Society Aid and Democracy Promotion, Washington, D.C.: Carnegie Endowment for International Peace, 2000, p. 191-215.

102. Kevin F.F. Quigley, 'Lofty Goals, Modest Results," p. 195.

103. Ibid.

104. Sada Aksartova "Promoting Civil Society or Diffusing NGOs?" in Hammack and Heydemann, pp. 160-191. For a similar criticism of the role of funders on civil society in Africa see Marina Ottaway, "Social Movements, Professionalization of Reform, and Democracy in Africa" in Marina Ottaway and Thomas Carothers, eds., Funding Virtue: Civil Society Aid and Democracy Promotion (Washington, D.C.: Carnegie Endowment for International Peace, 2000) pp. 77-104.

105. Quigley and Popson, 1999 p. 245-6

106. See MacArthur Foundation 2004 Annual Report, "A Foundation's Responsibility in Uncertain Times," in Jonathan Fanton, Foundations and Civil Society Volume One (Chicago: John D. and Catherine T. MacArthur Foundation, 2008) pp. 542-552.

107. Press release, May 29, 2009, macfound.org.

108. On conservative foundations, see John J. Miller, Strategic Investment in Ideas: How Two Foundations Reshaped America (Washington, D.C.: The Philanthropy Roundtable, 2003); Hudson Institute/Bradley Center, Vision and Philanthropy (Washington, DC: Hudson Institute; 2005); Jeff Krehely, Meaghan House and Emily Kernan, Axis of Ideology: Conservative Foundations and Public Policy (Washington: National Committee for Responsive Philanthropy, 2004).

109. M.J. Zuckerman, “Track II Diplomacy: Can "Unofficial" Talks Avert Disaster", Carnegie Reporter, Vol. 3, No. 3, Fall 2005. There is an extensive literature on Track II. See, for example: R.J. Fisher. Interactive Conflict Resolution. (Syracuse, NY: Syracuse University Press, 1997); H.H. Saunders, A Public Peace Process: Sustained Dialogue to Transform Racial and Ethnic Conflicts (New York: St. Martin's Press, 1999).

110. www.ncafp.org/projects/northeast_asia With support from Ford, Luce and MacArthur, the NCAFP also runs Track II dialogues among Americans, Taiwanese, and Chinese in an effort to ease tensions across the Taiwan straits.
111. Interviews with Vartan Gregorian, President, Carnegie Corporation of New York and Stephen J. Del Rosso, Program Director, International Peace and Security, International Program, Carnegie Corporation.

112. In 2008, the American side went public with its proposal for addressing the US-Iran nuclear standoff that was co-authored by dialogue members and endorsed by former senior officials in both Democratic and Republican Administrations. The proposal analyzed Iran's nuclear program, offered a new multilateral approach to solving the nuclear problem, and proposed an agenda for a new American policy of engagement with Iran. See William Luers, Thomas R. Pickering, Jim Walsh, "A Solution for the US-Iran Nuclear Standoff" The New York Review of Books, Vol. 55, No. 4, March 20, 2008.

113. Interview with Stephen Heintz and Rockefeller Brothers Fund internal documents.

114. Ibid. In 2007 the Rockefeller Brothers Fund also used its Pocantico Conference facility to host another type of foundation supported diplomacy. This was a 2007 meeting of Kosovar Albanian leaders, chaired in part by the President of RBF and also attended by senior Americans including former President Bill Clinton, former Secretary of State Madeleine Albright, and Undersecretary of State Nicolas Burns. The meeting was one step in a long negotiating process towards eventual independence for Kosovo. See Henry H. Perritt, Jr., The Road to Independence for Kosovo: A Chronicle of the Ahtisaari Plan (Cambridge: Cambridge University Press, 2010), pp. 177.

115. See Tim G. Evans and Lincoln C. Chen, "PublicPrivate Partnerships in Global Health, Rockefeller Foundation Paper; Mark R. Kramer, "Philanthropy, Aid, and Investment: Alignment for Impact" in Brainerd and Chollet, pp. 216-224.

116. See Edwards, Just Another Emperor. For examples of evaluation of civil society programs see David C. Hammack and Steven Heydemann, eds., Globalization, Philanthropy, and Civil Society: Projecting institutional Logics Abroad (Bloomington and Indianapolis: Indiana University Press, 2009).

117. One example of foundation cooperation on evaluation is Grantmakers for Effective Organizations or GEO. See www.geofunders.org

118. See especially Joel L. Fleischman, The Foundation: A Great American Secret: How Private Wealth is Changing the World (New York: Public Affairs, 2007); David C. Hammack and Steven Heydemann, eds., Globalization, Philanthropy, and Civil Society; Projecting Institutional Logics Abroad (Bloomington and Indianapolis: Indiana University Press, 2009); and others cited in this study.

119. Exceptions include Berman and Figer. David C. Hammack and Steven Heydemann, eds. Globalization, Philanthropy, and Civil Society: Projecting institutional Logics Abroad (Bloomington and Indianopolis: Indiana University Press, 2009). On the role of actors other than states, see Akira Iriye Global Community: The Role of International Organizations in the Making of the Contemporary World (Berkeley: University of California Press, 2002); Maryann K. Cusimano, ed., Beyond Sovereignty: Issues for a Global Agenda (Boston: Bedford/St. Martin's 2000). Ann M. Florini, ed. The Third Force: The Rise of Transnational Civil Society (Washington: Carnegie Endowment for International Peace, 2000)
120. For an exception see OECD, Development Assistance Committee, "Philanthropic Foundations and Development Co-operation," DAC Journal 2003, Volume 4, No. 3, 2004.

121. On governance see Joseph S. Nye and John D. Donahue, eds., Governance in a Globalizing World, (Washington, D.C.: Brookings Institution Press, 2000) especially L. David Brown, Sanjeev Khagram, Mark H. Moore, and Peter Frumkin, "Globalization, NGOs, and Multisectoral Relations," pp. 271-296.

122. See Joseph S. Nye, Jr., Soft Power: The Means to Success in World Politics (New York: Public Affairs, 2004).

123. See Fleischman pp. 152-155 on lack of accountability of foundations.

124. See Peter Frumkin, "Accountability and Legitimacy in American Foundation Philanthropy" in Prewitt et al, op cit., pp. 99-122.

125. See: Scott Sherman, “Target Ford," The Nation, June 5, 2006.

126. See David Hammack, op. cit.

127. See Marina Ottaway, op. cit, and Sada Aksartova, op. cit. and Ann Swidler, op. cit.

128. See Fleischman pp. 150-152 for criticisms of foundation staff.

129. See Shana Warren and Robert Lloyd, "Civil Society and Self-Regulation: The Global Picture", Briefing Paper number 119, June 2009, One World Trust., London. www.oneworldtrust.org

130. Principles of Accountability for International Philanthropy, Council on Foundations and European Foundation Center, 2007.

131. See, for example, Health Alliance International, "NGO Code of Conduct for Health System Strengthening Initiative," (Seattle: Health Alliance International, May 2008). www.ngocodeofconduct.org

\section{See www.ceres.org}

133. See www.sustainability-indexes.com

\section{See www.oneworldtrust.org}

135. See United Nations Development Program, Arab Human Development Reports at www.arab-hdr.org

136. For an example of criticism of Ford Foundation funding of Palestinian projects see www.ngomonitor.org/editions/v1n10/v1n10-1.htm

137. Interview with Stephen Heintz, President, Rockefeller Brothers Foundation. 
FOUNDATION CENTER

Knowledge to build on.

79 Fifth Avenue • New York, NY $10003 \bullet(800)$ 424-9836 • foundationcenter.org 